\title{
Stonehenge - a unique Late Cretaceous phosphatic Chalk geology: implications for sea-level, climate and tectonics and impact on engineering and archaeology
}

\author{
Rory N. Mortimore ${ }^{1,2}$, Liam T. Gallagher ${ }^{3}$, James T. Gelder ${ }^{4}$, Ian Moore ${ }^{5}$, Richard Brooks ${ }^{5}$ \\ and Andrew R. Farrant ${ }^{6}$
}

1. School of the Environment and Technology, University of Brighton, Moulsecoomb, BRIGHTON BN2 4GJ

U.K.

2. ChalkRock Limited, 32 Prince Edwards Road, LEWES, Sussex BN7 1BE

3. Network Stratigraphic Consulting Ltd, Harvest House, Cranborne Road, Potters Bar, Hertfordshire, U.K. EN6 3JF

4. Mott MacDonald, St Anne House, Wellesley Road, CROYDON CR9 2UL U.K.

5. CH2M, Elms House, 43 Brook Green, London W6 7EF U.K.

6. British Geological Survey, Keyworth, NOTTINGHAM, NG12 5GG

\begin{abstract}
Summary: Ground investigations for the A303 Stonehenge Tunnels revealed a unique and complex Chalk geology including the presence of the thickest ( $>20 \mathrm{~m}$ thick), and previously unknown phosphatic chalks in England, partly filling fault controlled erosional channels. The use of natural gamma-ray borehole logs to determine the presence and thickness of the phosphatic deposits is of particular value and combined with the lithostratigraphy, macrofossil and nannofossil biostratigraphy from cores has, for the first time, accurately constrained the Coniacian to Santonian age and the lenticular geometry of such deposits. Four phosphatic chalk events between 88.5-86.5 Ma are recognised associated with synsedimentary faulting. We suggest a causal link between tectonics, subsidence and channel-formation, phosphatisation events, pulses of oceanic upwelling on a frequency of about 0.5 million years to mantle-controlled plate tectonic episodes. The implications of this geology for construction of the A303 and the archaeology of the area are discussed.
\end{abstract}

\section{Introduction}

The A303 is a major trunk road between London and southwest England and traffic flows on the section between Amesbury and Winterbourne Stoke, Wiltshire (the section that includes Stonehenge) have been above the capacity of the road for some years. In 1995, Highways England put forward proposals to upgrade the A303 past Stonehenge. This included a cutand-cover tunnel excavated in Upper Cretaceous Chalk. Rejection of a cut-and cover option led to new plans in 2002 for a $2.1 \mathrm{~km}$ (1.3 miles) bored tunnel with an estimated cost of $£ 183$ million. Ground investigations for the A303 Stonehenge Tunnels revealed a complex succession of phosphatic chalks $>20$ m thick (Figures 1-3).

Phosphatic chalks are rare in Europe, generally occurring as small outcrops or subcrops as local channel-fills in southern England and northern France (e.g. Jarvis, 1980, 1992, 2006; Mortimore and Pomerol, 1987). It was a complete surprise, therefore, to find the thickest phosphatic chalks in England during the 2001-2002 investigations (Mortimore, 2001) for the proposed A303 Stonehenge tunnels (Figure 3). The nearest phosphatic Chalk deposits of a similar age to Stonehenge (Figure 1) are at Boxford and Winterbourne north of Newbury in Berkshire and Taplow (South Lodge Pit) near Maidenhead, Buckinghamshire (Strahan, 1891, 1895; Hawkins, 1948; Jarvis, 1980, 1992; Jarvis and Woodroof, 1981). Limited exposure and no or few boreholes have made these other localities difficult to analyse and interpret. Many of these deposits also have little or no surface expression, making them very difficult to identify without excavations or boreholes. More extensive, mined deposits in the Somme Basin, northern France (Pomerol et al., 1980; Monciardini, 1989), have been used as analogues for the English deposits (Jarvis, 1980, 1992, 2006). At none of these localities has 
it been possible to completely reconstruct the total age range and sequence of geological events that formed these phosphatic chalks. The great number of cored boreholes and geophysical logs through the Stonehenge deposits are a first chance to provide a more complete geological setting for such deposits in Europe and assess the wider implications for Cretaceous marine environments. We argue that tectonic movements created the sea-bed setting and space for at least the thickest phosphatic chalk deposits at Stonehenge during a period of relative sea-level high which included oscillations and pulses of oceanic upwelling possibly related to mantle-controlled plate tectonics. In this respect the Stonehenge geological setting appears to have greater affinity with the fault-controlled phosphatic chalks of the Mons Basin, Belgium (Robaszynski, 1989) rather than the submarine-channel formed deposits of northern France (Jarvis, 1992, 2006).

Cancellation of the original proposed A303 Stonehenge Tunnels and the Amesbury to Winterbourne Stoke improvements was in large part due to the unexpected geology and unexpected groundwater conditions around Stonehenge which led to construction costs more than doubling to $£ 470$ million in July 2005 . Whether such geology also has implications for the archaeology of Stonehenge and location of flint mines is discussed.

\section{Discoveries during the A303 Stonehenge ground investigation}

Rotary cored boreholes drilled during the first A303 Stonehenge (Amesbury to Winterbourne Stoke investigation improvements Figures 3-4) in 2001 identified 'normal' white chalk with flint bands. One borehole (BHR12, Figure 4 section D), however, indicated the presence of an unusual deposit of phosphatic chalk (Mortimore, 2001). The surprise at finding previously unknown phosphatic chalks at Stonehenge was reinforced during the second ground investigation. This time, one borehole (BHR142, Figure 4 section D) recorded the thickest known phosphatic chalk deposits in England (Mortimore, 2003). Other boreholes and trial pits were then checked and the phosphatic chalk deposits appeared to be present over an area west of Stonehenge Bottom (Figures 3-5). Evidence from lithological and fossil marker beds gave a clue to the age of these deposits and knowledge from other phosphatic deposits in southern England and northern France (e.g. Jarvis, 1980, 1992, 2006) provided clues to the chemistry of the sediments and the likely form of the sedimentary bodies.

\section{Sorting out the stratigraphy, borehole correlations and geological long sections}

Little specific geological information is available from the published literature along the proposed new route of the A303. When ground investigations started, the most up to date geological map was that surveyed on the six-inch scale, in 1903. This shows the whole route as being underlain by 'Upper Chalk'. The accompanying geological survey memoirs (Clement Reid, 1903; Jukes-Browne \& Hill, 1904) identify some former Chalk exposures to the south around Salisbury and around Marlborough on the north side of Salisbury Plain although the exact localities of the exposures are sometimes difficult to determine. The memoirs also record some useful data from wells driven into the Chalk (e.g. at Enford). 
More recently, subsequent to the ground investigation, the British Geological Survey remapped the Stonehenge area at 1:10,000 scale as part of the 1:50,000 scale Salisbury Sheet 298 resurvey (Farrant et al., 2005; Hopson et al., 2005; 2008). The mapping included logging sections and analysis of macro- and micro-fossil samples collected during the survey, including from sites along the route of the proposed tunnels (Figure 4). Most of the significant exposures described in the literature and identified during field mapping are from quarries along river valleys or old pits along the Chalk escarpment many kilometres to the north, west and south of Stonehenge. Some of these exposures were subsequently logged prior to this investigation or during the resurvey (e.g. Beggars Knoll, Quarry, Westbury and many small exposures around Warminster, Mere and Salisbury e.g. Mortimore, 1986). Most of these logs are published in Mortimore, Wood, \& Gallois (2001) and in BGS memoirs (Hopson et al., 2005, 2008). The only quarries in the region close to the route are in the valley of the River Till (e.g. the exposure of Chalk Rock at Berwick St. James to the south of Winterbourne Stoke), and in the valley of the River Avon (Seaford and Newhaven Chalk formations at Middle and Lower Woodford and Old Sarum Hill, Salisbury, Figure 2). The existing data indicated that much of the proposed A303 route was likely to be developed in the Seaford Chalk Formation or possibly the lower part of the Newhaven Chalk Formation.

Given the lack of site specific information from boreholes or exposures along the proposed route prior to the ground investigation phase, together with the lack of any topographical expression and the apparently highly localised nature of the phosphatic chalk deposits, it is not surprising that the discovery of phosphatic chalks and the consequent complexity of the geology in the area of Stonehenge Bottom had not been appreciated before the investigations began.

\section{Evidence from the A303 Site Investigation data}

Without any major exposures of Chalk the correlation framework for the A303 Stonehenge (Figure 5) has been constructed primarily from boreholes and trial pits using every bit of evidence from the chalk lithologies and fossils to identify marker beds such as the Belle Tout Marls and the beds with abundant inoceramid bivalve fossils. Subsequent to the ground investigation further information from BGS field slips, (with notes on lithology and micro/macro palaeontology) has been added to construct the long section (Figures 4-5). The evidence suggests that the Seaford Chalk Formation is present to the east of Stonehenge Bottom (Figures 3-5). The upper $10 \mathrm{~m}$ of Borehole R158 is above the upper band of abundant Platyceramus (a fossil bivalve) in the upper Haven Brow Beds and Deep Trial Pit DTP 159 excavated to the west of BHR158 and near BHP3 contained the fossil echinoid Conulus albogalerus typical of the Haven Brow beds in the upper part of the Seaford Chalk Formation (Lower and Middle Santonian) and basal Newhaven Chalk Formation (Splash Point Beds). The nearby Trial Pit DTP160 (Figures 4-5) yielded abundant fossil inoceramid bivalves with affinities to Sphenoceramus characteristic of the Haven Brow Beds. The combination of these fossils suggests an horizon close to the boundary of the Seaford and Newhaven Chalk formations. Seaford Chalk comes to the surface to the west of Stonehenge Bottom close to the position of borehole R8 (Figures 4-5). Newhaven Chalk (Uintacrinus socialis and 
Marsupites testudinarius zones), occupies the high ground immediately adjacent to Stonehenge Bottom and the phosphatic chalks are partly developed from this stratigraphical level downwards on the west side of Stonehenge Bottom. Newhaven Chalk overlies the phosphatic chalks (Mortimore, 2001 and Figures 5-6; Farrant et al., 2005) and caps the high ground to the east near West Amesbury.

Westwards, older beds of chalk emerge at the surface proved by fossils obtained from trial pits. DTP136 yielded fragments of the fossil inoceramid bivalve Cladoceramus undulatoplicatus typical of the basal Haven Brow Beds (Figure 4), DTP133 contained cap valve shells of Volviceramus cf involutus (J. de C. Sowerby) in the Belle Tout Beds around the Seven Sisters Flint band (i.e. above the Belle Tout Marls). From DTP131 large forms of the fossil echinoid Micraster cf. M. turonensis (Figure 6) were collected (possibly from beds around the Seven Sisters Flint Band and basal Cuckmere Beds). Large inflated forms of Micraster (cf. M. gibbus (Lamarck)) from DTP128 (Figure 6) indicate a return to the basal Haven Brow Beds. In borehole R129 the Adur Marl in the Cuckmere Beds of the Seaford Chalk Formation has been identified and correlated to similar marl seams in boreholes R9 and R138. Major faulting or a marked change in dip (possibly a fold) is required to explain this distribution of chalk beds (Figure 5).

In the valley of the River Till boreholes R123 and R124 contained typical nodular chalk horizons of the Lewes Nodular Chalk Formation and glauconite, iron and calcite mineralised hardgrounds characteristic of the Chalk Rock (Figure 5). Seaford Chalk Formation caps the high ground on both the east and west sides of the valley of the River Till (Figures 3 and 4 section A). West of the Till valley, abundant Platyceramus and Volviceramus was found, often associated with a small, but pronounced positive break of slope close to the base of the valley draining east into the Till valley from Yarnbury Castle hillfort. All the valleys in this area have incised down to the same level, indicating an easterly dip. Hence the broad dip of strata must be eastwards. On the west side of the River Till, chalk with numerous marl seams and shells were present in DTP115 (probably Belle Tout Marls and Platyceramus?).

Micraster obtained from DTP113 have affinities with high zonal M. coranguinum? (Leske). Borehole R111 had only a single band of inoceramids (Platyceramus) at a depth of $13.80 \mathrm{~m}$. This stratigraphical evidence suggests that the dip may be steeper on the west side of the River Till. Correlation of the Chalk Rock hardgrounds found in boreholes 122-124, on either side of the River Till, show this to be a fault controlled river-valley with a throw on the fault down to the east of approximately $6.0 \mathrm{~m}$ (Figure 5).

The stratigraphical analysis indicates that the Lewes Nodular Chalk Formation is about $19 \mathrm{~m}$ thick and the Seaford Chalk Formation is approximately 70-80 m thick. These thicknesses and the altitude of key marker beds are used to determine the geological structure of the area shown on the long-sections (Figure 5).

Very few diagnostic macrofossils have been found within the phosphatic chalk intervals. The first evidence for stratigraphical position came from macrofossils below and above the phosphatic chalks linked to lithological marker beds (marl seams and flint bands). Key 
macrofossils records are shown against each trial pit along the line of the investigation (Figure 4) and for each borehole (Figures 4 and 5). Key elements of the macrofossil records included the inoceramid bivalve fossils with the Platyceramus-Volviceramus co-occurrences diagnostic of the Belle Tout Beds and Cladoceramus undulatoplicatus diagnostic of the basal Santonian at the base of the Haven Brow Beds at levels including the equivalent horizon of Bedwell's Columnar Flint. These fossil inoceramid bivalves were found in borehole cores and trial pits outside the phosphatic chalk deposits (e.g Volviceramus in DTP133, Figure 4 and Cladoceramus in DTP136, Figure 4). Other macrofossils, especially various species of the fossil echinoid Micraster (Figure 6), aided stratigraphical interpretation (Figures 4 and 5 and individual borehole $\log \mathrm{s})$.

To help identify the spatial extent of the phosphatic chalks, 21 microfossil determinations taken from surface field brash in the surrounding area in May and June 2003, were analysed at BGS (published as BGS internal reports; Wilkinson 2004a, 2004b). This micropalaeontological evidence helped confirm the lithostratigraphic mapping (Figures 2 and 4) and supported the core and trial pit macropalaeontological evidence showing that most of the area surrounding the phosphatic chalks consisted of mid-upper Seaford Chalk Formation (Haven Brow beds). Sponge beds and pink-cortex flints were locally present. Newhaven Chalk Formation, as well as covering the phosphatic chalks (Figure 5), was present at one locality outside of the phosphatic-chalk channels on Conybury Hill, $1.5 \mathrm{~km}$ southeast of Stonehenge (Figure 4 section D). The Newhaven Chalk covering the phosphatic chalk channels appeared to be quite flinty from surface brash confirming borehole observations (Figures 7 and 9 and 11-13).

Results from the macrofossil, microfossil and lithological marker bed records provided a broad correlation framework within which the phosphatic chalks could be provisionally placed and the equivalent horizon of some key southern England Chalk marker beds identified. Correlation of the individual phosphatic chalk horizons remained uncertain with only dashed-tie-lines between boreholes (e.g. Mortimore, 2014, fig. 3.26b, p. 149). Detailed correlation of these phosphatic chalks was essential to developing a full sedimentary model for the deposits showing the number of events and their ages, the depth of erosion of possible chalk-seafloor submarine channels and their continuity and/or the extent of faults controlling sedimentation and/or subsidence. Only with such a model could the impact on tunnelling and other engineering operations (earthworks, slopes, landscaping, hydrogeology) be properly assessed. After the A303 road scheme had been cancelled a more detailed biostratigraphical analysis was undertaken as part of a research programme, looking at the distribution of macro- and nannofossils in several sets of borehole cores. Borehole R11, which contained the greatest number of phosphatic chalk horizons, was selected as the standard for this study.

\section{Key stratigraphical control Borehole R11 nannofossil analyses and age of the phosphatic chalks}

Borehole R11, because it contained the most horizons of phosphatic chalks, separated by 'normal' chalks, was chosen as the standard for further detailed stratigraphical analyses using 
nannofossils. The results (Figure 7; Table 1 and Appendix 1) have been compared with the Seaford Head section, Sussex coastal cliffs (Figures 8-10), where the zonal scheme for both the micro- and nannofossils has been developed for the chalk facies of northwest Europe (Hampton et al., 2007). Using the standard nannofossil zones the four main phosphatic chalk events (Figure 7) are dated between 88.5 Ma and 86. $5 \mathrm{Ma}$ (i.e. spanning 2 million years from the Late Coniacian to the Middle Santonian). A particular feature of the nannofossil biostratigraphy is the Last Occurrence (LO) of abundant Helicolithus trabeculatus at $22.00 \mathrm{~m}$ depth in borehole R11. This same nannofossil event is closely associated with the Flat Hill/Bedwell's Columnar Flint in the Seaford Head section in the Early Santonian. This nannofossil event divides the phosphatic chalks at Stonehenge into two. Events 1 and 2 are in the Late Coniacian and Events 3 and 4 are in the Middle Santonian.

The nannofossil biostratigraphy (Table 1; Appendix 1, Figure 10) has also provided the evidence confirming the presence of several key Chalk marker beds including the Belle Tout Marls and Seven Sisters Flint Band beneath the phosphatic chalks (e.g. in boreholes R11 and R16, Figure 9). These beds are associated with abundant fossil inoceramid shell fragments (Platyceramus-Volviceramus). The nannofossil analyses have further helped identify the equivalent stratigraphical position of other key litho-marker beds including the Brasspoint and Whitaker's Three Inch Flint bands and Barrois' Sponge Bed in the Seaford Chalk and Hawks Brow Flint in the Newhaven Chalk (Figures 7-9). Barrois' Sponge Bed is possibly equated with a well-developed green coated glauconitic hardground at $13.20 \mathrm{~m}$ depth in Borehole R11. It is also possible that the hardground equates with the British Geological Survey Stockbridge Rock Member mapped on the Salisbury Sheet (Hopson et al., 2005). The Stockbridge Rock Member is a hard bed several metres below Barrois' sponge bed. It is localised within a part of the Wessex basin controlled by syn-sedimentary faulting/folding along the line the Winchester-Dean Hill anticline (Figure 2).

Building on the evidence from Borehole R11, samples from four further cored boreholes have been analysed for nannofossil distribution including Borehole R142 containing the thickest phosphatic chalks (Figures 9-12; Table 1).

A key outcome from the nannofossil biostratigraphy is the demonstration that the thickest phosphatic chalks (BHR142, Figure 11) are part of the third main phosphatic chalk event in the Middle Santonian (BHR11 Figure 7). The results also suggest that there are more marl seams in the Seaford Chalk Formation than recorded elsewhere in southern England, especially in the Early and Middle Santonian (e.g. boreholes R9, R142, R20 Figures 11 and 12). This unusual 'marly' succession in the Early Santonian is associated with fragmented inoceramid bivalve debris, which, on the basis of stratigraphical position, is presumed to be related to Cladoceramus undulatoplicatus. Using all the macro- nannofossil and lithological evidence boreholes have been correlated along the line of the proposed A303 improvements (e.g. Figures 5 and 12-13). 
Table 1: Comments on nannofossil biostratigraphy obtained from boreholes R9, R11, R16, R20 and R142 (also see Appendix 1 for details of BHR11)

\begin{tabular}{|c|c|c|}
\hline & Samples & Comments \\
\hline & & $\begin{array}{l}\text { On the east side of the correlation there is a 'contrast' between } \\
\text { boreholes } \mathrm{R} 16 \& \mathrm{R} 20 .\end{array}$ \\
\hline R16 & $\begin{array}{l}\text { On the east side of } \\
\text { Stonehenge Bottom } \\
\text { Sampled every metre } \\
\text { downhole from } 2 \mathrm{~m} \text { to } 36 \mathrm{~m} \\
\text { (samples at } 12 \text { and } 15 \mathrm{~m} \text { not } \\
\text { available due to core-loss) }\end{array}$ & $\begin{array}{l}\text { The top of R16 is already within "abundant } H \text {. trabeculatus" with } \\
\text { increased numbers of } B \text {. parca expansa downhole and consistent } Q \text {. } \\
\text { eptabrachium from } 15 \mathrm{~m} \text { \& below. This is equivalent to Late } \\
\text { Coniacian, UC11ii at SFH between SFH100 and then SFH110 at } 15 \mathrm{~m} \text {. } \\
\text { Close to the bottom of this borehole } H \text {. trabeculatus reduces in } \\
\text { abundance (= SFH } 120 \text { ) and would correlate with a position just } \\
\text { above Belle Tout Marls (as suggested by your correlation panel). }\end{array}$ \\
\hline \multirow[t]{2}{*}{$\mathrm{R} 20$} & $\begin{array}{l}\text { To the east of R16 } \\
\text { Sampled every metre } \\
\text { downhole from } 3 \mathrm{~m} \text { to } 26.40 \\
\mathrm{~m} \text { (sample at } 12 \text { not } \\
\text { available) }\end{array}$ & $\begin{array}{l}\text { In R20 there is } A \text {. cymbiformis var. NT down to } 23 \mathrm{~m} \text { and } H \text {. } \\
\text { trabeculatus does not show any increase (=SFH } 95 \text { ?) until } 26 \mathrm{~m} \text {. This } \\
\text { has to be higher stratigraphically than the entire R16 borehole. }\end{array}$ \\
\hline & & $\begin{array}{l}\text { To the west of Stonehenge Bottom there is greater effect of the } \\
\text { phosphate on nannofossil preservation and reworking }\end{array}$ \\
\hline R11 & $\begin{array}{l}\text { The key reference borehole } \\
\text { with the four phosphatic } \\
\text { chalk events separated by } \\
\text { normal white chalk. } \\
\text { Sampled every metre and/or } \\
\text { at changes in lithology } \\
\text { See detailed results in } \\
\text { Appendix } 1\end{array}$ & $\begin{array}{l}\text { R11 has channel fill between } 27 \mathrm{~m} \text { and } 35 \mathrm{~m} \text { where it reduces the } \\
\text { overall abundance of the nanno recovery, but is not detrimental to the } \\
\text { overall picture. There is no A. cymbiformis var. NT in this section and } \\
\text { there are incremental abundance shifts in } H \text {. trabeculatus at } 18 \mathrm{~m} \text { and } \\
\text { then again at } 21 \mathrm{~m} \text { (=SFH100) - spot on with the Bedwell's correlation } \\
\text { at Seaford Head and also in the Thames boreholes. The increase in } B \text {. } \\
\text { parca expansa at } 23 \mathrm{~m} \text { is also spot on as an event we have seen just } \\
\text { under Bedwell's Columnar Flint in other studies. } \\
\text { At } 42 \mathrm{~m} \text { the last downhole occurrence of } L \text {. grillii should occur just } \\
\text { above the Cuckmere Sponge Bed. The last downhole influx of } H \text {. } \\
\text { trabeculatus at } 44.5 \mathrm{~m} \text { has previously been associated with the } \\
\text { Cuckmere Flints close to the Belle Tout Marls. }\end{array}$ \\
\hline R142 & $\begin{array}{l}\text { The borehole with the } \\
\text { thickest phosphatic chalks as } \\
\text { part of Event } 3\end{array}$ & $\begin{array}{l}\text { R142: This is a difficult borehole as the data is 'more' compromised } \\
\text { in the upperpart by the phosphates. However, the lower part below } \\
34 \mathrm{~m} \text { is clear: There is still abundant } H \text {. trabeculatus down to at least } \\
44 \mathrm{~m} \text { with consistent } Q \text {. eptabrachium coming in at } 42 \mathrm{~m} \text { and } \\
\text { consistent } L \text {. grillii going out at } 38 \mathrm{~m} \text {. This all happens in SFH110 - } \\
120 \text { but not as low as Belle Tout Marls. The flint at } 41.5 \text { could be a } \\
\text { Cuckmere Flint just above the Seven Sisters Flint Band (i.e. the } \\
\text { borehole ends nearly at the base of the Cuckmere Beds, Seaford Chalk } \\
\text { Formation) }\end{array}$ \\
\hline \multirow[t]{11}{*}{ R142 } & $\begin{array}{l}\text { Sample numbers at metres } \\
\text { depth }\end{array}$ & $\begin{array}{l}\text { An example of sampling strategy. Samples taken at metre intervals } \\
\text { and/or at a particular feature in the sediments. }\end{array}$ \\
\hline & 2 & In white chalks above phosphates \\
\hline & 3 & ditto \\
\hline & 4 & ditto \\
\hline & 5 & ditto \\
\hline & 6 & ditto \\
\hline & 7 & Just above first phosphate bed entering at $7.20 \mathrm{~m}$ \\
\hline & 8 & Just below first phosphate bed \\
\hline & 9 & In white chalk \\
\hline & 10 & Just above gritty chalks and below a good marl seam \\
\hline & 11.20 & In chalks with burrow-fill phosphates \\
\hline
\end{tabular}




\begin{tabular}{|l|l|l|}
\hline & 12 & ditto \\
\hline & 13 & Just above beginning of main phosphate beds \\
\hline & 14 & In Phosphates \\
\hline & 15 & ditto \\
\hline & 17 & No sample 16 \\
\hline & 18 & In Phosphates \\
\hline R9 & & In Phosphates \\
\hline & $\begin{array}{l}\text { R9: Again the best evidence in this borehole is at the base where an } \\
\text { increase in } \text { H. trabeculatus suggests it just penetrates the equivalent } \\
\text { horizon of the of Brasspoint Flint (=SFH 95). Above this there is a } \\
\text { base to common Calculites at 4m and very rare A. cymbiformis var. } \\
\text { NT down to 6m. }\end{array}$ \\
\hline
\end{tabular}

SFH=Seaford Head SFH120= Seaford Head sample numbers in Hampton et al., 2007 and Figure 10.

\section{How many phosphatic chalk channels, depth of erosion, lateral extent and fault control of the deposits?}

The evidence from the site investigation boreholes and trial pits suggests that the phosphatic chalks are restricted laterally at Stonehenge to between Chainage 9100 and Chainage 8280 of the Published A303 Road Scheme and (vertically) to ground above $50 \mathrm{mAOD}$ (Figures 5 and 13-16). The phosphatic chalks are lenticular in section being thickest in the vicinity of R142/R142A (Chainage 8700 approx.) and thinning to the east and west. At the thickest point they are covered by some $10 \mathrm{~m}$ of 'normal' chalk. However, the upper boundary rises to the east and west (and possibly the north), with extrapolation suggesting the phosphatic chalks may reach the surface just west of trial pit DTP21 (Chainage 8280) and just east of borehole R152 (Chainage 9100), where at the top of the east-facing slope of Stonehenge Bottom phosphatic-chalk-rich Head deposits were exposed in trial pits. Textural evidence suggests that these materials may have been derived, in part at least, from colluvial phosphate material. Faulting recognised by the displacement of the Belle Tout Marls (below the phosphatic chalks, Figures 5 and 16-17) between cored boreholes, has segmented the phosphate deposits and offset a portion of it upward. Part of this apparent offset in the phosphatic chalk could also be due to the presence of a localised channel cutting down through the normal, already faulted Chalk. North-south downfaulting appears to be the locus of deposition for the thickest deposits found in boreholes R142 and R12 (Figures 5, 15-17).

Critical to identification of the faults and their sense of throw is the accuracy of the bed-level stratigraphy. Recognising the Belle Tout Marls and associated abundant fossil bivalve inoceramid shell fragments (e.g. Mortimore, 1986; 2014, figs. 1.66-1.67, p.46) in cores from boreholes R138, R11, R146, R13 and R16 helped define beds below the phosphatic chalks, the strata dip and differences in elevation of these beds caused by faults (Figures 5, 16 and 17). Originally, it was thought that the lowest part of BHR142 also penetrated the Belle Tout Beds. Nannofossil biostratigraphy, however, shows that this borehole ends in the Cuckmere Beds of the Seaford Chalk Formation (Figures 7 and 16). Nannofossil biostratigraphy 
confirmed the identification of the Belle Tout Beds in boreholes R11 and R16 and also aided identification of the equivalent horizons for the Bedwell's Columnar Flint and Whitaker's Three Inch flint bands (e.g. in borehole R11, Figures 7 and 12). It is with this evidence that the faults shown on the long sections are identified. Despite this evidence there are still uncertainties in the correlations and it is probable that there are many more faults along these sections.

\section{Evidence from geophysical borehole logs}

Natural gamma geophysical borehole logs in the same and adjacent boreholes (BHR142 and BHR142a, Figure 11) confirmed the core-log evidence for the presence of the thickest known phosphatic chalks in England. Comparison between the detailed lithological core-log and the natural gamma-log profiles for the same boreholes indicates a very high degree of correlation (BHR142, Figure 11) and this gave confidence that the natural gamma profiles from other boreholes could be used to infer the geographhical and stratigraphical limits of the phosphatic chalks in the areas between core-logged boreholes. No threshold API value has been assumed and the presence of phosphates is inferred based on the relative difference between background 'noise' and conspicuous gamma-log peaks in each individual borehole. Natural gamma-log spikes indicating the presence of marl seams in the chalks beneath the phosphatic deposits are also confirmed by the core lithological logs (Figures 11 and 14a,b).

The natural gamma-logs for boreholes R142 and R142A suggest that a significant, discrete, northeast-southwest trending, possibly-fault-controlled channel, containing a substantial thickness $(>15 \mathrm{~m})$ of the weakest phosphatic lithologies, may exist in the vicinity of Chainage 8700 (Figures 11 and 15). The line of natural gamma borehole logs including those for R143P, R140P, R139P and R138P (Figure 14a) also suggest that a smaller channel (>2 $\mathrm{m}$ of phosphatic chalk) towards the western margin of the deposits trends northwards. In summary, the phosphatic chalks resemble a series of channels, some fault-controlled, trending north to northeastwards under Stonehenge. Natural gamma borehole logs along the eastern side of the phosphtaic chalks (Figure 14b; boreholes 13P and 15AP) illustrate the signal in terms of gamma spikes produced by weakly phosphatic chalks seen in cored borehole R13.

Field mapping by BGS confirms this general trend (Farrant et al., 2005; Figure 4). Faulting identified by the displacement of the Belle Tout Marls suggests that the deposits are confined eastwards by north trending faults along Stonehenge Bottom. Several other faults are present in the areas containing the thickest phosphatic deposits. The coincidence of faults and phosphatic chalk channels suggests a close relationship between tectonic movements and the presence of these deposits. On current evidence it appears that some faults may be truncated by some channels indicating synsedimentary fault movements (Figures 16-17).

\section{Correlation of boreholes and sedimentary models for the phosphatic chalks}

On the basis of core logging, geophysics, lithostratigraphy and biostratigrphy the phosphatic material is interpreted as being formed in a number of crosscutting and/or ramifying 
submarine, chalk-seafloor channels (Figures 16-17). If this model for the formation of phosphatic chalks is accepted and given the 20+ metres thickness of phosphatic chalk in Borehole R142, there could be channel-floor downcutting of at least $20 \mathrm{~m}$ through preformed 'normal' Seaford Chalk at Stonehenge (Figure 8a,b). Alternatively or additionally, downfaulting may have provided the space and locus for phosphatic chalk deposition (a subsidence model).

Despite the litho- and biostratigraphical evidence for the borehole correlations used to construct the geological sections (Figures 5, 16 and 17) there are still several uncertainties. These uncertainties include the number of faults especially associated with the phosphatic chalks and in the sections to both east and west of Stonehenge Bottom. The combination of faults and the depth of erosion of the various channels makes establishing the thicknesses and variations within the lithostratigraphical divisions difficult. Assumptions have been made about the constant thicknesses of beds (other than the channel-fills) so that the long-sections can be constructed. This assumption seems reasonable as marker beds can be traced outside the areas where channels are present. Remaining anomalies are the thicknesses and precise dip of beds east of Stonehenge and the folding and/or faulting west of Stonehenge. The shape of the outcrop and subcrop of the Newhaven Chalk above the phosphatic chalks (e.g. Figure 5) and its correlation eastward of Stonehenge Bottom is also uncertain. Without the bed level stratigraphy for the Chalk none of the faults shown in the long sections would have been identified (e.g. if only the Chalk formations had been used the section would have shown mostly Seaford Chalk), and the fault control on sedimentation would not have been recognised.

\section{Nature of material}

The Stonehenge phosphatic chalks are largely made of pelletal, detrital material including shelly fragments of fossils, phosphatised fossil pellets and reworked phosphatised sponges. Several hardgrounds (hardened sea-floors), mineralised with calcite, green glauconite and brown phosphates are present within many of the deposits and at the base of some of the smaller 'channels' (Figure 17). There is little evidence, however, of major hardgrounds with sufficient, precipitated phosphates to provide the source of the main, thicker phosphate beds, suggesting that the deposits have been reworked from another locality. They appear to have a lenticular form in cross-section but their full longitudinal extent cannot be determined from the present investigations. A provisional correlation of the deposits shows the nature of probable channels in the Chalk (Figures 15-16). There is sufficient evidence to define the eastern and western limits of the deposits and to define the azimuthal trend of the channels including the thickest deposits (Figure 15).

The term 'Phosphatic Chalk' is used here to describe a number of lithologies, of varying phosphatic content. These lithologies range from well-cemented, weakly-phosphatic hardgrounds, to very weakly cemented, friable, richly-phosphatic sandy silstones. The majority of these lithologies are weaker than 'normal' white chalk; however, the hardground lithologies could, in some instances, be significantly harder and stronger than the 'normal' 
chalks. The sand fraction of the phosphatic chalk comprises a fine to medium sand of subangular to angular cryptocrystalline apatite (Ca5[F (PO4)3]). This phosphate is thought to be largely derived from reworked hardgrounds. The silt matrix in which the phosphate sand is generally supported is thought to represent the calcareous silt from which 'normal' chalks are composed. In some instances (i.e. in particularly sand-grade horizons) the phosphatic lithologies at Stonehenge can border on being clast supported. Intervals of 'sand' noted in the core recovered from borehole R142 (17.4-18.0 mBGL and 22.9-24.1 mBGL) may indicate the presence of 'locked sands', i.e. sand-grade phosphatic chalks with negligible cementation, within the bedded phosphatic succession. Preliminary analyses suggest that, as in other phosphatic chalks, absence of benthic algal grains, algal borings or filaments and macrophytic structures on attachment areas of encrusters and the presence of only marine phreatic cements indicate deposition below the photic zone (Jarvis, 1980, 1992) on the seabed (i.e. depths $>70-100 \mathrm{~m}$ ).

A variety of phosphatic lithologies have been grouped under the general term 'phosphaticchalk', identified visually in core from boreholes R9, R11, R12, R13, R15A, R138, R142, R146 and R149 (Figure 1). These lithologies have also been observed in-situ in trial pit DTP21. Natural Gamma geophysical borehole-log profiles have been used to further define the extent of the phosphatic chalk deposits in boreholes R142A, W137, R138B, R139, R140, $\mathrm{R} 141, \mathrm{R} 143$ and P2. Where the concentrations of phosphatic material are reduced geophysical logs illustrate this (e.g. boreholes R13P and R15AP, Figure 14b) and compare with the core descriptions for borehole R13 showing less phosphate (Figure 14b).

Phosphatic-chalk lithologies encountered at this site are unusual. In addition to beds of phosphate-rich hardgrounds and phosphatic pebble beds, there are thick intervals $(>15 \mathrm{~m}$ in borehole R142) of very weakly-cemented, friable sandy siltstone (pelletal phosphate) which is easily distinguished from pure white chalks by its beige/brown sandy appearance in the core. Such unusually thick deposits require a source on some local sea-bed high where precipitated phosphates are then re-worked by submarine currents into local channels. The trend of the channels (Figure 15) appears to follow the trend of the faults along and adjacent to Stonehenge Bottom (Figure 15-17).

The results suggest that phosphatic chalk formation at Stonehenge lasted about 2 million years starting in the Middle Coniacian (c.88.5 million years) and continuing into the Late Santonian ( 86.5 million years) in a series of geological 'events' represented by (i) a number of either sea-bed 'erosional' syn-Chalk channels cutting down through at least $20 \mathrm{~m}$ of Seaford Chalk and/or, (ii) influxes of reworked phosphates into 'normal' chalks of the Seaford and Newhaven Chalk formations (Figures 16 and 17) in an area of localised, faultcontrolled subsidence. Four main phosphatic chalk horizons are recognised (Figure 7). Event 3, with the thickest phosphatic-chalk deposits, occurred in the Middle Santonian (87.0-86.8 Ma).

A feature of the phosphatic chalks is the near absence of flint bands (Table 2) in these intervals including in the weakly phosphatic chalks containing reworked chalk pebbles (e.g. 
Borehole R13, Figure 14b). Flint bands in the white chalk intervals, in the 'normal' stratigraphy, have the same spacing expected for this part of the Chalk in this region. The reason for the reduction in flint bands in the phosphatic chalk is related to the way in which flint forms in the sediment of the chalk seabed. Initial nucleation of silica ions takes place within the sediment of the seabed. If this process is disturbed by reworking of the chalk, for example because of erosion and transportation of sediment, then the nucleation process is halted and the silica disseminated. Formation of phosphatic chalks, like flint formation, requires high organic productivity. One process may partially or completely exclude the other.

There is evidence for traceable flint bands in the 'normal chalk succession' between boreholes. The correlation is more secure using the combination of marl seams, flint bands and fossil abundance levels. The evidence from the core-logs suggests that flint frequency and percentage flint in a tunnel face is less of a problem here than at many other sites. Some large flints may, however, be encountered as individual nodules. There are also implications for location of Prehistoric flint mines (see below).

Table 2. Flint band frequency (spacing) per borehole with and without phosphatic chalks

\begin{tabular}{|c|c|c|}
\hline Borehole & $\begin{array}{l}\text { Flint band frequency in white chalk } \\
\text { (spacing per metre) }\end{array}$ & $\begin{array}{l}\text { Flint band frequency in } \\
\text { phosphatic chalk (spacing per } \\
\text { metre) }\end{array}$ \\
\hline BHR9 & 15 flint bands in $20 \mathrm{~m}$ & $\begin{array}{l}2 \text { flint bands in } 14 \mathrm{~m} \text { (small flints } \\
\text { only) } \\
7 \mathrm{~m} \text { but } 10 \mathrm{~m} \text { without flint }\end{array}$ \\
\hline BHR12 & $\begin{array}{l}4 \text { flint bands (very small tubular flints) in the } \\
\text { interval above the phosphatic chalk }(0-7 \mathrm{~m} \\
\text { depth) }\end{array}$ & $\begin{array}{l}\text { No flint in the phosphatic chalks } \\
\text { (8-24m depth) }\end{array}$ \\
\hline BHR11 & $\begin{array}{l}5 \text { flint bands in white chalk interval below } \\
\text { First Main Phosphate Bed (39-45m depth) } \\
3 \text { flint bands in the white chalk interval } \\
\text { between the Second and Third Phosphate beds } \\
(17-26 \mathrm{~m})\end{array}$ & $\begin{array}{l}2 \text { flint bands (in white chalk } \\
\text { between phosphates) in the } \\
\text { interval containing the First and } \\
\text { Second Main Phosphate beds } \\
\text { (26-39m depth) } \\
2 \text { scattered small flint bands in } \\
\text { the phosphatic chalks }\end{array}$ \\
\hline BHR13 & $\begin{array}{l}29 \text { flint bands in the interval below the } \\
\text { phosphatic chalk ( } 22-50 \mathrm{~m} \text { depth) }\end{array}$ & $\begin{array}{l}\text { No flint bands in the interval } \\
\text { with phosphatic chalk pebbles } \\
(12-21 \mathrm{~m} \text { depth) }\end{array}$ \\
\hline BHR16 & 23 flint bands in $36 \mathrm{~m}$ & No phosphatic chalk \\
\hline BHR18 & $\begin{array}{l}29 \text { flint bands in } 51 \mathrm{~m} \\
10 \mathrm{~m} \text { interval from } 3-13 \mathrm{~m} \text { depth virtually flint } \\
\text { free (one flint band) }\end{array}$ & $\begin{array}{l}\text { No phosphatic chalk (possibly } \\
\text { reworked chalk) }\end{array}$ \\
\hline BHR20 & 26 flint bands in $34 \mathrm{~m}$ ( $1 \mathrm{~m}$ missing core $)$ & No phosphatic chalk \\
\hline BHR142 & $\begin{array}{l}12 \text { flint bands in the topmost } 13 \mathrm{~m} \\
\text { No flint bands between } 13.00-32 \mathrm{~m} \text { in the main } \\
\text { phosphatic chalks and no flints in the interval } \\
\text { from } 32.0-40.00 \mathrm{~m} \text { with reworked, } \\
\text { phosphatised fragmented shells }\end{array}$ & $\begin{array}{l}\text { No flint bands in the main } \\
\text { phosphatic chalks or re-worked } \\
\text { intervals }\end{array}$ \\
\hline
\end{tabular}




\section{Discussion: implications of the discovery for geology}

A key geological feature of the Stonehenge deposits is the close relationship of faulting with the location and probable formation of the phosphatic chalk deposits. This suggests that synsedimentary (i.e. intra-chalk) tectonics controlled the timing and the area where submarine-erosion channels were to form. The idea is supported by the northerly direction of the channels identified from the many boreholes and field mapping.

The different ages of the phosphtaic chalks (Figure 7) demonstrate that there are several 'events' and therefore several potential channels rather than one single very large channel linking all the phosphatic chalk deposits. It is possible that the two thickest phosphatic chalks seen in boreholes R12 and R142 are part of one very large channel system (Figures 16b and 17b). An aspect that cannot be determined from boreholes alone is the three dimensional nature of either the larger or smaller deposits, (whether they are channels or not). Some of the smaller 'channels' may represent the proximal beginnings of larger channels (e.g. Figures 17 and 18) whose distal size may be similar to those containing the thickest deposits. Based solely on the Stonehenge boreholes it would also not be possible to be confident about the sedimentary processes producing the phosphatic chalks.

Size and shape of the Stonehenge phosphatic-chalk-filled channels compare closely with other Chalk channels such as the Early Turonian Hooken - Wilmington trough/channel, southeast Devon (Mortimore et al., 2001). Channels trend north from the Hooken to Wilmington following fault trends. Faults in the same north-south direction also control the position of Stonehenge phosphatic chalks and channel system. This fault-controlled model for creating space for phosphatic chalk sedimentation compares closely with the model developed for the Mons Basin Maastrichtian phosphatic chalks (Vandycke et al., 1991; Figures 19-21). Such a fault-controlled subsidence model does not require deep sea-bed erosion by 'channelling' that characterises the deposits in the Somme or at South Lodge Pit Taplow (e.g. Mortimore et al., 2001 and references therein). In the case of the Somme (Beauval) and Taplow examples, well developed glauconitic and phosphatic chalk hardgrounds are present beneath the phosphatic chalks representing the mineralised channelfloor surfaces. This contrasts with the Stonehenge deposits where there is no clear evidence of hardgrounds beneath the main deposits. On the contrary hardgrounds appear to be at the top of the deposits (e.g. boreholes R9 and R11 Figures 7 and 13) similar to the hardground at the top of the Ciply Chalk, Mons Basin (Figures 20-21). These observations suggest that subsidence, probably fault-controlled, is responsible for creating the space for the thickest phosphatic chalk deposits in Northwest Europe including the Mons Basin and Stonehenge. Only in some of the 'smaller' channels found at Stonehenge do hardgrounds appear to be present (Figure 17a). These may be at the proximal, narrower ends and/or on the margins or lips of the channels (Figure 18). Well developed, glauconite mineralised hardgrounds are also present within the phosphatic channel-fills (Figure 17a) indicating several 'events' in a channel forming and filling process (i.e. a subsidence model rather than one channel-forming event). Other glauconitic hardgrounds appear not to be associated with any phosphatic chalks (e.g. Borehole R18 on the east side of Stonehenge Bottom, Figures 5 and 16). 
Unlike the Mons Basin, where the deep geology has at least been explored by deep boreholes and seismic sections, at Stonehenge, apart from the A303 investigations, the area is virtually unexplored territory and there is no direct evidence for tectonic controls on sedimentation. Deep in the crust beneath Stonehenge are two potential structural-fault trends. The first is the Bristol Channel southerly dipping, east-west trending thrust fault system in the deep underlying basement (Pharaoh et al, 1996). North-south faulting may, however, be reflecting deep underlying structures related to the north-south Worcester Graben (Figure 24). If this is the case this would be the first evidence for the rejuvenation and influence of this tectonic trend on sedimentation in this part of England in the Late Cretaceous (Coniacian to Santonian). Elsewhere in the Late Cretaceous in England, north-south fault controlled sedimentation has been recognised in the Upper Cretaceous. Examples include the northsouth, fault- controlled channel (the Hooken-Wilmington trough, Devon) in which the BeerStone formed in the Early Turonian (Mortimore et al., 2001, figs. 3.19-21, pp 109-111). At Mupe Bay on the Dorset coast an intra-Cenomanian north-south fault controls the change in lithology and thickness of Albian-Cenomanian sediments (Strahan, 1898; Drummond 1970). Combining the observations from several disparate small localities where unusual, coarse phosphatic or bioclastic chalks have formed or where there are sharp changes in sediment including disrupted horizons (e.g. Boxford, the Hooken and Mupe Bay), strengthens the argument for episodic periods of structural control on chalk sedimentation. This observation is supported by tectonic controls described for the Somme Basin phosphatic chalk deposits, France (Monciardini, 1989) and the Mons Basin deposits in Belgium (Robaszynski, 1989; Vandycke et al., 1991).

Illustrations of the synsedimentary faulting in the Mons Basin Ciply phosphatic chalks in particular (Vandycke et al., 1991; Figures 20-21) provide an analogue for the faulted phosphatic chalks on the west side of Stonehenge Bottom. In both areas phosphatic chalks thicken laterally over short distances and step-thicken over faults. The wider geological setting of the Mons Basin may be different to Stonehenge as it is suggested that the Maastrichtian Ciply phosphatic chalks fill a subsiding basin rather than 'channels'. Controls on this basin subsidence and associated faulting are partly explained by dissolution collapse of karstified evaporite layers in the Visean (Carboniferous) as well as tectonic fault movements during the Late Cretaceous

Palaeostress studies on faults in the European Platform Mesozoic and Cenozoic sedimentary cover (Hibsch et al., 1993, 1995; Figure 24) suggest that lateral shear rejuvenated major basement faults (Lake and Karner, 1987), in turn generating new fault activity in cover sediments (Mortimore, 2011). Stonehenge lies close to the junction point between the NWSE Hercynian Front structures and the north-south Worcester Graben structures (Figure 24). Episodic rejuvenation of these deep faults probably created the local, normal-faulting at Stonehenge and possibly uplifted a ridge or shelf area nearby. Further north-south faults are recorded to the south of Stonehenge (Farrant et al., 2005). There is no clear evidence, however, for a major tectonic feature in the area beneath or near Stonehenge. Nevertheless, 
the presence at Stonehenge of north-south faulting, combined with the phosphatic chalks, suggests that there is a substantial tectonic structure influencing sedimentation in the vicinity.

The presence of north-south faulting only explains the probable creation of channels or thick deposits of phosphatic chalk at Stonehenge and does not help identify the origin of the phosphates. Most models for marine sedimentary phosphate generation require upwelling/advection, of deep nutrient rich sea-water onto a shelf area where water mass mixing generates high organic activity to produce precipitated phosphates (e.g. Reiss, 1988; Flexer et al., 1986, 1989; Jarvis, 1980, 1982, 2006; Mortimore, 2011, fig.58). It is probable that there was a sea-bed high (a Stonehenge Ridge or Shelf), possibly to the north of or west of Stonehenge, which acted as the required submarine high for upwelling over which phosphates precipitated and were then eroded and re-worked into the fault controlled Stonehenge channel system. Such a submarine high itself was probably fault controlled. A possible conduit for nutrient rich oceanic waters from the opening Atlantic was the Bristol Channel between the Cornubian and Welsh massifs and over the Mendip Line (Figure 24). The Late Coniacian and Santonian coincided with a period of major plate tectonic movements including the rotation of the African-Arabian plate (Guiraud, and Bosworth, 1999; Bosworth et al, 1999). These plate movements had a major impact on growth tectonics in Europe especially the re-activation and reversal the direction of basement faults influencing Chalk sedimentation (Mortimore and Pomerol, 1991, 1997; Mortimore 2011). The impact of these movements on oceanic circulation is uncertain, however, the coincidence of widespread phosphatic chalk deposition over a period of approximately two million years in cycles of about 0.5 to 1.0 million years (third order cycles of Vail et al, 1977) at a time of such plate tectonic movements suggests a link between tectonics, oceanic current circulation and nutrient upwelling. At Stonehenge the four main phosphatic-chalk events (Figure 7) possibly represent four oceanic upwelling events in 2 million years, probably as a response to African-European plate movements recognised by Bosworth et al., 1999.

Other phosphatic chalk 'events' in southern England range in age from the Cenomanian to Campanian (Figures 22-23). Some of these such as the phosphatic chalks of Chichester have no exposures (known only in building stones such as Boxgrove Priory, Chichester, and Chichester Cathedral, containing many Early Campanian fossils). Other deposits demonstrably fill erosional channels including the mid'-Cenomanian Southerham Grey Pit Channel, Lewes, Sussex (Mortimore, 2013), the Middle Turonian Glyndebourne Hardgrounds and phosphatic chalks (Mortimore, 1986; Mortimore \& Pomerol, 1987); the Late Turonian Strahan's Hardground and phosphatic chalks at Lewes (Mortimore 1986b). Similarly the 'mid'-Cenomanian Totternhoe Stone at Totternhoe, Bedfordshire (Mortimore et al., 2001 and references therein), has formed on an erosional channel. Each of these examples has a special geological setting. The Lewes and Glyndebourne examples are closely associated with the fault controlled Kingston anticline - Caburn syncline (Mortimore \& Pomerol, 1987; 1991). The Totternhoe Stone formed on the fault-controlled Chilterns Shelf. These examples suggest a close association between tectonic setting and erosional channels in the Chalk. The Stonehenge examples are unique in terms of thickness and the evidence for fault-controlled subsidence. 
Very high and rising sea-levels (>200m above present, Hancock, 2000) coincided with the Middle Coniacian to Late Santonian, when the phosphates were forming at Stonehenge. Relative sea-levels did, however, fluctuate. Many causes have been sought for high frequency changes in relative sea-level including polar ice sheets (Jeans et al., 1991; Lovell, 2010). The Late Cretaceous has generally been considered to be a period without significant polar ice. Ephemeral polar ice sheets have been postulated to explain some Late Cretaceous deposits at the Cenomanian - Turonian boundary (Jeans et al., 1991). Present evidence points, however, to 'hot-house' temperatures at least in northern Polar regions during the later Late Cretaceous as relative sea-levels reached their maximum (Hancock, 2000, Jenkyns et al., 2004). The combined evidence from well-dated phosphate deposits and synsedimentary faulting at Stonehenge lends support to the idea that both relative sea-level fluctuations and tectonic movements are interlinked. Such an observation supports Lovell (2010) who used a mantle convection model with pulsating cells to explain tectonic movements and high frequency cycles in relative sea-levels. A combination of tectonic uplift and cycles in relative sea-level probably created the environment for upwelling and phosphate formation at Stonehenge. This interpretation differs from the erosional cuvette model generally used to interpret such deposits (Jarvis, 1992, 2006).

If our interpretation of fault controlled sedimentation is correct then the phosphatic chalks would be expected to extend under Stonehenge itself along the direction of the faults (Figure 15). There is also the possibility for even larger channels and thicker phosphatic chalks being present in the area. Such interpretations have significant implications for construction of tunnels and the hydrogeology of the area.

\section{Implications for engineering}

Producing a conceptual geological model that helps predict likely ground conditions along the line of the proposed A303 Stonehenge tunnels requires identifying the extent of different lithologies and tectonic structures as well as depth of weathering (CIRIA grades, Lord et al., 2002) and groundwater conditions. Tunnelling engineers are experienced at dealing with 'normal' chalks with flint bands and marl seams. Unexpected geology such as the presence of friable, sandy-phosphatic chalks raises questions about the behaviour of this unknown material in terms of support required in an open-face tunnel, spoil behaviour and spoil chemistry (Figures 25-27).

Early assessments of the phosphatic chalks indicated layers with varying degrees of phosphatic material. The graphical borehole logs (e.g. Figures 11-13) are a first attempt to show this variation. Where the phosphatic material is most concentrated the beige-brown colour of the core and the fine sand grade material is more pronounced and the core-logs reflect this in the colours used. The potential engineering behaviour of the phosphatic chalks became evident when core-lengths of the most concentrated phosphatic material were lifted from the core-boxes and fragmented easily in the hand to silt, sand and gravel-sized pieces. A key issue for tunnel support is whether these deposits will produce 'running-sand' in a tunnel 
face or whether the deposits are strong enough to maintain a 'roof' of more competent normal chalks for the proposed open-shield approach, along with an invert capable of supporting the shield and support systems (e.g. support an 'Elephants foot'; ELEPHANT'S FEET are enlarged bearing areas at the bases of partially constructed linings, normally of the crown section, to support the crown-arch). Such issues will dictate how proposed tunnels will be constructed, especially whether open face tunnelling is possible and whether to go to a closed system of tunnelling with tunnel-boring machines (TBMs). A particular issue is the potential length of tunnel in the most concentrated phosphatic material which requires an accurate interpretation of the sedimentary model and extrapolation of borehole stratigraphy across the site. Dimensions for a typical tunnel face are plotted onto borehole logs at a potential tunnelling horizon to illustrate the variation in lithology that might be present in an open-face tunnel (Figure 25).

A visit during the 2002-2003 investigations to the phosphatic chalks in the Somme at Beauval in France, highlighted how burrowed and bored-hardgrounds in the roof of a tunnel (i.e. mottled/spotted normal chalks with phosphatic chalk burrow-fills, Figures 11-12) could be a useful risk indictor of phosphatic chalks existing immediately above the crown of the tunnel bore and perhaps a warning sign during construction of imminent stability risks. The relatively high risk of a 'poor crown zone' in terms of stability suggested by Figure 25 (and full-face zone elsewhere, e.g. R142 and R12) was a key observation that ultimately played a large part in the escalation in perceived tunnelling risks and hence costs, and ultimately, to the shelving of the scheme.

In addition to lithology, the depth of weathering reflected in the frequency of fracturing and openness of fractures and fracture fills influences tunnel support requirements. These aspects of Chalk geology are reflected in the CIRIA grades (Lord et al., 2002) and are plotted along the Stonehenge proposed tunnel section (Figure 27a-c). CIRIA grade D represents the destructured, periglacially fragmented chalk near the ground surface. Grades $\mathrm{C}$ to A in downhole order represent increasingly structured chalk from closely fractured open fractures (grade C) generally beneath destructured grade D to closed and possibly more widely spaced fractures (grade A). Grade D chalks and overlying Head deposits would be expected to thicken downslope into Stonehenge Bottom. Fractures would also be expected to be more open and permeable along the margins of Stonehenge Bottom as a result of valley-wards stress relief (e.g. Borehole R154, Figures 26 and 27a). In contrast, the interfluve areas have tighter rock conditions with closed fractures (e.g. boreholes R21 and R158 Figure 27a). The phosphatic chalk intervals are generally less fractured with much more mixed ground conditions in terms of CIRIA grade and in terms of permeability (e.g. borehole R142, Figures 11,26 and 27a).

The possibility of Radon Gas from the potential radioactive minerals in the deposit and the solubility of the phosphates with regard to groundwater contamination are major environmental issues. Solubility has not yet been tested but the high relative gamma radiation intervals shown on the geophysical borehole logs suggests the potential exists for Radon gas, especially as calcium phosphate is extremely rich in RADIUM 226 (Radon's parent). 
Disposal of tunneling spoil is a further key issue on such projects. An unknown related to the phosphatic chalks and the solubility of the calcium phosphate minerals is the impact such spoil might have on the local vegetation if used for landscaping.

\section{Groundwater hydrogeology}

A second major surprise at Stonehenge is the groundwater behaviour. During 2001 water levels rose from well below the invert of the proposed tunnels to previously unrecorded high levels that flooded Stonehenge Bottom and some trial pits. Permeability studies carried out as part of the A303 Stonehenge investigations (Figure 26) illustrated that the highest permeability zones are associated with the phospatic chalks and the faulted fracture zones associated with Stonehenge Bottom (Figure 26; Mortimore, 2012). Low permeability 'tight' zones are primarily associated with interfluves in less fractured chalk. In the least permeable interfluves groundwater flow appears to be focussed on bedding and subhorizontal features. This pattern of permeability is similar to observations made in the South Downs where downhole-cameras have logged flows along marl seams and recorded open fissures along dry valley margins (Molyneux, 2012). Field mapping by BGS indicates that base of the Till valley must be at or close to the base of the Seaford Chalk. Abundant springs rise at this point, up to $0.5 \mathrm{~km}$ north of the current A303, along the Lewes Chalk - Seaford Chalk interface. As part of the ground investigations at Stonehenge pumping trials in test wells were carried out and monitored in the network of Environment Agency and other ground investigation boreholes in the area. These pumping tests demonstrated that an open fracture network existed and pumping was drawing on a huge reservoir in the Chalk.

A key environmental issue related to pumping down the water levels so that open-face tunnelling could be undertaken. Disposal of phosphate-rich groundwater to specially protected rivers such as the River Avon (Figure 28) could be harmful to the flora and fauna of the river.

\section{Baseline conditions for engineering}

Combining the sedimentary model with the CIRIA grades and the predicted groundwater profile provides the baseline conditions for tunnelling. The worst baseline conditions (Figure 27c) assume a single large channel of phosphatic chalks (i.e. longest length of tunnel in these deposits), weathered chalk with open fractures (CIRIA grade B), several fault zones and groundwater at least up to the surface of Stonehenge Bottom. Lengths of tunnel in the range of ground conditions identified (Figure 27) are then used to define 'engineering geological zones'.

An alternative baseline model assumes multiple smaller phosphatic chalk channels, no faults and reduced depths of weathering (Figure 27b). To partly solve these engineering and environmental issues the extent, shape and size of the phosphatic chalk deposits needs to be known. To accomplish this, a highly refined bed-level stratigraphical framework is first 
required, followed by an understanding of the sedimentary and tectonic processes involved in the formation of the deposits. Identifying the north-south trend of the deposits and their faulted margins makes it possible to predict likely lengths of possible tunnels in normal chalks and lengths in phosphatic chalks (Figures 15-17 and 27). If the thickest phosphatic chalks are located in the fault controlled channels this reduces the likelihood of finding such thick deposits outside the limits of the faults. Identifying the thickest deposits with Event 3 (Figure 6) suggests that if this part of the stratigraphy is missing elsewhere these thick phosphatic chalks are also likely to be missing.

\section{Implications for archaeology}

Geology has a great influence on landscape including shape of the ground, vegetation and groundwater in terms of potential springs and water sources. Such aspects also influence the flora and fauna and consequently habitation. The phosphatic deposits have little or no surface expression, and thus do not induce any special landscape features. Stonhenge is located on a plateau area with groundwater draining east towards the River Avon and south towards and beneath dry valleys including Stonehenge Bottom (Figure 28). Water supply would have been plentiful. At this stage an unknown in terms of impact on habitation is the influence phosphatic-chalks might have had on soil richness and flora and fauna. This partly depends on the solubility of the species of phosphates present in the soil and the extent of these deposits. Having discovered this new geology in the Chalk at Stonehenge further studies are required to assess its implications for landscape evolution and habitation.

A feature of the phosphatic-chalk deposits is the absence or reduced number of flint bands (e.g. boreholes R12 and R142, Figures 11 and 12 and Table 2). The Neolithic Flint Mines at Durrington Walls $3.2 \mathrm{~km}$ northeast of Stonehenge (Figure 3) are excavated in the Seaford and Newhaven Chalk Formations (Figure 2) (Upper Chalk of the old literature and not the Middle Chalk as published in archaeological journals, e.g. http://intarch.ac.uk/journal/issue26/2/4.html). These flint mines are located just east of the potential strike of the north-easterly trending Stonehenge faults and phosphatic-chalks which may have limited the lateral extent of flint bearing chalk and possibly limited the depth as well (i.e. flint mining may have been restricted to flint bands above the phosphatic chalks in the Newhaven Chalk Formation and/or east of any potential phosphatic chalk deposits). There is no evidence yet for phosphatic-chalk at Durrington Walls or in the immediate vicinity. There is also no borehole or field exposure evidence for the exact stratigraphical position of the Durrington Walls flint mines within the Chalk succession or which flint bands are present in the mines.

\section{Conclusions}

Discovery of the unique 88.5-86.5 million year old phosphatic chalks and associated tectonic structures at Stonehenge came from drilling site investigation boreholes for the proposed A303 Road improvements which included a road tunnel. A bed level stratigraphy for the Chalk had to be established before the geological setting could be constructed (Figure 5). Nannofossil biostratigraphy combined with micro- and macrofossil evidence and field 
mapping proved to be vital tools in this previously unknown geology where there were no field exposures apart from field brash. This emphasises the need to record and retain evidence from fossils on construction projects, evidence that is frequently lost. Once a stratigraphical framework is in place the geology and its implications for (i) the formation of phosphatic chalks (ii) engineering, (iii) hydrogeology and (iv) archaeology, can be investigated.

As a result of the Stonehenge geological investigations we have:

(i) Recognised four phosphatic-chalk forming events at Stonehenge (Events 1-4, Figure 7) over a period of two million years from the Middle Coniacian to Late Santonian

(ii) Suggested a new fault controlled subsidence model for the location and formation of phosphatic-chalks as an alternative to, or in conjunction with, the erosional cuvette model

(iii) A wider age range for phosphatic-chalk formation in the English Chalk (Figures 22-23) with the thickest deposits occurring in the Middle Santonian Event 3 at Stonehenge (c.87.0-86.8 Ma, Figure 8)

(iv) Recognised the influence of north-south faulting in the Stonehenge area which may be reflecting deeper basement controls on tectonics (Figure 24)

(v) Recognised north-south fault control on valleys such as Stonehenge Bottom and the River Till valley at Winterbourne Stoke (Figure 5)

(vi) Established a frequency of occurrence of phosphatic-chalk deposits which in turn links to high frequency changes in relative sea-level and oceanic upwelling during the Late Cretaceous in a global plate tectonic context.

(vii) The 2 million years of phosphatic-chalk formation in fault controlled channels coincides with Africa-European plate movements and probable changes in Atlantic Ocean currents from the Middle Coniacian to Late Santonian.

(viii) Identified the absence of flint in the phosphatic chalks and reworked chalk horizons, supporting the idea that the flint forming process within seabed chalks will be disturbed by resedimentation and reworking. Hence the initiation of flint formation must be a very early seabed process. The absence of flint improves tunnelling conditions but impacts on location of possible prehistoric flint mines.

The coincidence of faults and thick phosphatic-chalk deposits suggests the possible presence of deeper level tectonic structures in the Stonehenge area. Further research is needed to identify whether there are underlying structures that controlled (i) a possible sea-bed high (a Stonehenge Ridge) over which phosphatic deposits formed and (ii) controlled the normal faulting (possibly related to the north-south Worcester Graben structures).

The need to be able to build a geological ground model from first principles, using stratigraphy, palaeontology, sedimentology, geochemistry, structural geology and geomorphology is emphasised in this 'virgin' ground at Stonehenge so that engineering risk can be identified early and design decisions can take account of such variable ground conditions. Open-face tunnelling requires rock of sufficient strength to support the crown and 
to support an Elephants Foot at the base of a shield. During tunnelling, clues to possible overlying weak phosphatic chalk deposits include encountering chalks with burrow-fills of phosphatic chalks in the crown. This is an example of 'total-rock approach' in engineering geology (Mortimore, 2012) where all aspects of geology have to be considered. For the first time the impact of such phosphatic-chalk deposits on engineering design and groundwater behaviour can be assessed. Permeability and chemistry of the phosphatic-chalk and associated northerly trending fracture zones may have influenced fauna and flora locally at Stonehenge and, consequently, habitation potential. A near-absence of flint bands from the phosphatic-chalks may also have dictated where to locate nearby flint mines (e.g. at Durrington Walls).

Stonehenge geology provides a unique model for interpreting Upper Cretaceous geological events, assessing risk to future construction projects in such ground conditions and assessing archaeological potential. It would be useful if future work could include (i) additional boreholes or geophysical surveys away from the A303 route to investigate the spatial distribution of the phosphatic chalks and (ii) a passive seismic traverse across the region to investigate geological structures.

\section{Acknowledgements}

David Patterson of the Highways England has supported these investigations and kindly gave permission to publish results. Many geologists and engineers from Soil Mechanics Limited, WJ Pumping, Mott MacDonald and Halcrow Group Limited (now CH2M) contributed to the investigations. Ian Wilkinson (BGS) is thanked for his support in determining the microfossils from field brash in the area of Stonehenge which aided identification of the Chalk formations and beds in the course of field mapping.

\section{References}

Aldiss, D.T., Farrant, A.R. and Hopson, P.M., 2012. Geological mapping of the Late Cretaceous Chalk Group of southern England: a specialised application of landform interpretation. Proceedings of the Geologists' Association, 123,728-741.

Bosworth, W. Guiraud, R. and Kessler, L. G. 1999. Late Cretaceous ( $\pm 84 \mathrm{Ma}$ ) compressive deformation of the stable shield of NE Africa (Egypt) : far-field stress effects of the "Santonian event" and origin of the Syrian arc. Geology, 27, 633-636.

Bristow, C.R., Mortimore, R.N. and Wood, C.J. (1997) Lithostratigraphy for mapping the Chalk of southern England. Proceedings of the Geologists' Association, 108, 293-315.

British Geological Survey. 2005. Salisbury. England and Wales Sheet 298. Bedrock and Superficial Deposits. 1:50,000. (Keyworth, Nottingham; British Geological Survey).

Drummond, P.V.O., 1970. The Mid-Dorset Swell. Evidence of Albian - Cenomanian movements in Wessex. Proceedings of the Geologists' Association, 81, 679-714.

Farrant, A., Hopson, P.M., Booth, K.A., Newell, J., Marks, R.J., Aldiss, D.T., Barton, C.M., Royse, K.M. and Bristow, C.R. 2005. 1:50,000 Salisbury Sheet 298. British Geological Survey, Keyworth Nottingham.

Flexer, A., Rosenfeld, A., Lipson-Benitah, S., Honigstein, A., 1986. Relative Sea 
Level Changes During the Cretaceous in Israel. The American Association of Petroleum Geologists Bulletin, 70, 1685-1699.

Flexer, A., Gilat, A., Hirsch, F., Honigstein, A., Rosenfeld, A. \& Rueffer, T., 1989. Late Cretaceous evolution of the Judean Mountains as indicated by ostracodes. Terra Nova, 1, 349-358.

Guiraud, R., Bosworth, W. 1999. Phanerozoic geodynamic evolution of northeastern Africa and the northwestern Arabian platform. Tectonophysics, 315, 73-108. Gradstein, F.M., Ogg, J.G., Schmitz, M. \& Ogg, G. The Geologic Time Scale 2012. Published by Elsevier and the Geologic TimeScale Foundation website: https://engineering.purdue.edu/stratigraphy.

Hampton, M.J., Bailey, H.W., Gallagher, L.T., Mortimore, R.N. and Wood, C.J. 2007. The biostratigraphy of Seaford Head, Sussex, Southern England; an international reference section for the basal boundaries for the Santonian and Campanian Stages in chalk facies. Cretaceous Research, 28, 46-60.

Hancock, J.M. (1989) Sea level changes in the British region during the Late Cretaceous. Proceedings of the Geologists' Association, 100, 565-94.

Hancock, J.M. (2000) Late Cretaceous Eustatic Highs. Memoir geological Society of India, No.46, 1-14

Hawkins, H.L. (1948) 8. - British phosphates. Part 1. Phosphatic chalk of Taplow. Wartime Pamphlets.

Hibsch, C., Cushing, E.M., Cabrera, J., Mercier, J., Prasil, P., Jarrige, J.-J., 1993. Paleostress evolution in Great Britain from Permian to Cenozoic: a microtectonic approach to the geodynamic evolution of the southern U.K. basins. Bull. Cent. Rech. Explor. Prod. Elf Aquitaine Production, F-31360 Boussens, 17, 303-330.

Hibsch, C., Jarrige, J.-J., Cushing, E.M., Mercier, J., 1995. Paleostress analysis, a contribution to the understanding of basin tectonics and geodynamic evolution. Example of the Permian/Cenozoic tectonics of Great Britain and geodynamic implications in western Europe. Tectonophysics, 252, 103-136.

Hopson, P.M., Farrant, A.R., Newell, A.J., Marks, R.J., Booth, K.A., Bateson, L.B., Woods, M.A., Wilkinson, I.P. Brayson, J. \& Evans, D.J. 2007. Geology of the Salisbury District - a brief explanation of the geological map. Sheet Explanation of the British Geological Survey. 1:50,000 Sheet 298 Salisbury (England and Wales). 38 pp. NERC, Keyworth, Nottingham.

Jarvis, I. (1980) The initiation of phosphatic chalk sedimentation - the Senonian (Cretaceous of the Anglo-Paris Basin). The Society of Economic Paleontologists and Mineralogists Special Publication No. 29, 167-92.

Jarvis, I. (1992) Sedimentology, geochemistry and origin of phosphatic chalks: the Upper Cretaceous deposits of NW Europe. Sedimentology, 39, 55-97.

Jarvis, I. 2006. The Santonian - Campanian phosphatic chalks of England and France.

Proceedings of the Geologists' Association, 117, 219-237.

Jarvis, I. and Woodroof, P.B. (1981) The phosphatic chalks and hardgrounds of Boxford and Winterbourne, Berkshire - two tectonically controlled facies in the late Coniacian to early Campanian (Cretaceous) of southern England. Geological Magazine, 118, 17587.

Jukes-Browne, A.J. \& Hill, W. 1904. The Cretaceous Rocks of Britain. Volume 3. The Upper Chalk of England. Memoir of the Geological Survey of the United Kingdom. H.M.S.O. London.

Lake, S.D., Karner, G.D., 1987. The structure and evolution of the Wessex Basin, 
southern England: an example of inversion tectonics. Tectonophysics, 137, 347-378.

Lord, J.A., Clayton, C.R.I. \& Mortimore, R.N. 2002. Engineering in chalk. Construction Industry Research and Information Association. CIRIA Publictaion C574. 350pp. London

Lovell, B. 2010. A pulse in the planet : regional control of high-frequency changes in relative sea-level by mantle convection. Journal of the Geological Society, London, 167, 637648.

Molyneux, I. 2012. Hydrogeological characterisation of the Chalk: with specific reference to unsaturated zone behaviour. $\mathrm{PhD}$ thesis, University of Brighton.

Monciardini, C. 1989. The Senonian (Cretaceous) phosphatic chalks of the Paris Basin, France. In: (eds.) Notholt, A.J.G., Sheldon, R.P. and Davidson, D.F. 1989. Phosphate deposits of the World.Volume 2. Phosphate rock resources. Cambridge University Press. pp. 407-410.

Mortimore, R.N. 1983. The stratigraphy and sedimentation of the Turonian - Campanian in the Southern Province of England. Zitteliana, 10, 27-41.

Mortimore, R.N. 1986a. Stratigraphy of the Upper Cretaceous White Chalk of Sussex. Proceedings of the Geologists' Association, 97, 97-139.

Mortimore, R.N. 1986b. Controls on Upper Cretaceous sedimentation in the South Downs with particular reference to flint distribution. In The scientific study of flint and chert (eds G. de G. Sieveking and M.B. Hart), Cambridge University Press, Cambridge, pp. 21-42.

Mortimore, 2001. Stratigraphical logging of cores for the A303 Stonehenge proposed tunnels: preliminary results. Report for the attention of Kevin Roberts, Mott MacDonald Site Office, C/O Wiltshire County Council, Highways Depot, Station Cotts, London Road Amesbury, SP4 7QA 26 ${ }^{\text {th }}$ March, 2001. 4 pages plus core-logs. 1 of 3 reports March-April 2001 with core-logs and interpretations of the geology.

Mortimore, R.N. 2002. A303 Amesbury-Berwick Down Stonehenge (incorporating the Winterbourne Stoke Bypass) Geological Report. January 2002. 15 pp. plus diagrams and borehole logs. Report prepared for Nick Burt/Ian Moore, Halcrow Group Limited Vineyard House, 44 Brook Green Hammersmith LONDON W6 7BY

Mortimore, R.N. 2003. A303 Amesbury-Berwick Down Stonehenge (incorporating the Winterbourne Stoke Bypass) Geological Report. $25^{\text {th }}$ January 2003. 18 pp. plus diagrams and borehole logs. Report prepared for Nick Burt/Ian Moore, Halcrow Group Limited Vineyard House, 44 Brook Green Hammersmith LONDON W6 7BY (3 reports between November 2002 and February 2003 with borehole logs and interpretations of the geology).

Mortimore, R.N. 2011. A Chalk Revolution: what have we done to the Chalk of England? Proceedings of the Geologists' Association, 122, 232-297.

Mortimore, R.N. 2012. Making sense of Chalk: a total-rock approach to its Engineering Geology. Quarterly Journal of Engineering Geology and Hydrogeology, 45, 252-334.

Mortimore, R.N. 2013. Geoconservation and the advancement of geosciences: lessons from the Chalk of England. Proceedings of the Geologists' Association, 124, 593-611.

Mortimore, R.N. 2014. Logging the Chalk. Whittles Publishing, Dunbeath, Caithness, Scotland. $357 \mathrm{pp}$.

Mortimore R.N. and Pomerol, B. 1987. Correlation of the Upper Cretaceous White Chalk (Turonian to Campanian) in the Anglo-Paris Basin. Proceedings of the Geologists' Association, 98, 97-143.

Mortimore, R.N. and Pomerol, B. 1991 Upper Cretaceous tectonic disruptions in a placid Chalk sequence in the Anglo-Paris Basin. Journal of the Geological Society, London, 
148, 391-404

Mortimore, R.N. and Pomerol, B. 1997. Upper Cretaceous tectonic phases and end Cretaceous inversion in the Chalk of the Anglo-Paris Basin. Proceedings of the Geologists' Association, 108, 231-55.

Mortimore, R.N. Wood, C.J., Gallois, R.W., 2001. British Upper Cretaceous Stratigraphy. Geological Conservation Review Series, 23, Joint Nature Conservation Committee, Peterborough. 558pp.

Nielsen, S. B., Thomsen, E., Hansen, D.L., Clausen, O.R., 2005. Plate-wide stress relaxation explains European Palaeocene basin inversions. Nature, 435, 195198.

Nielsen, S. B., Stephensen, R., Thomsen, E., 2007. Dynamics of Mid-Palaeocene North Atlantic rifting linked with European intra-plate deformations. Nature, 450, 1071-1074.

Pharaoh, T.C., Morris, J.H., Long, C.B. and Ryan, P.D. 1996. 1:1,500,000 Tectonic Map of Britain, Ireland and adjacent areas. British Geological Survey, Keyworth, Nottingham.

Pomerol, B. (1976) Géochimie des craies du Cap d'Antifer (Haute Normandie). Bulletin de la Société géologique de France, (7), 18,1051-60.

Pomerol, B. (1983) Geochemistry of the Late Cenomanian - Early Turonian Chalks of the Paris Basin: Managanese and Carbon Isotopes in Carbonates as Paleooceanographic Indicators. Cretaceous Research, 4, 85-93.

Pomerol, B., Cautru, J.-P. and Monciardini, C. 1980. La craie de Picardie: ses phosphates et ses accidents magnésiens. Bulletin d'Information Géologues du Bassin de Paris, 17, $11 \mathrm{pp}$.

Reid, C. 1903. The geology of the country around Salisbury. Memoir of the Geological Survey of Great Britain, Sheet 298 (England and Wales). H.M.S.O. London.

Reiss, Z., 1988. Assemblages from a Senonian high-productivity sea. Revue de Paléobiologie, Spécial Volume No. 2, Benthos '86, 323-332.

Robaszynski, F. 1989. The Phosphatic Chalk of the Mons Basin, Belgium. In: (eds.) Notholt, A.J.G., Sheldon, R.P. and Davidson, D.F. 1989. Phosphate deposits of the World. Volume 2. Phosphate rock resources. Cambridge University Press. pp. 370-375.

Robaszynski, F. and Martin, M. 1988. Late Cretaceous phosphate stratiform deposits of the Mons Basin (Belgium). In: (eds) Boissonnas, J. and Omenetto, P. Mineral deposits in the European Community. Springer Verlag, Berlin, Heidelberg, 515-529.

Strahan, A. (1891) On a phosphatic chalk with Belemnitella quadrata at Taplow. Quarterly Journal of the Geological Society of London, 47, 356-67.

Strahan, A. (1895) Phosphatic chalk at Taplow, Berks. Geological Magazine, Decade 4, 2 , 336.

Strahan, A., 1898. The Geology of the Isle of Purbeck and Weymouth. Memoirs of the Geological Survey (England and Wales), HMSO, London.

Vandycke, S., Bergerat, F., Dupuis, C. 1991. Meso-cenozoic faulting and inferred palaeostresses in the Mons Basin, Belgium. 1991. Tectonophysics, 192, 261-271.

Wilkinson, I.P. 2004a. Late Cretaceous foraminifera from the area around Stonehenge. British Geological Survey Internal Report, IR/04/080.

Wilkinson, I.P. 2004b. Foraminifera from a suite of Chalk samples from near Stonehenge. British Geological Survey Internal Report, IR/04/083. 


\title{
Appendix 1: \\ STONEHENGE BOREHOLE R11 NANNOFOSSIL BIOSTRATIGRAPHY \\ LATE CRETACEOUS
}

\section{SAMPLE 8.00m (f.s.e.):}

\author{
LATE SANTONIAN
}

Sample age based on:

\begin{abstract}
the occurrence of Amphizygus brooksii, Broinsonia parca expansa, Cylindralithus biarcus, Grantarhabdus coronadventis, Lithastrinus grillii, Lucianorhabdus species, Micula staurophora, Zeugrhabdotus biperforatus and super abundant Watznaueria barnesae in the highest sample examined at $8.00 \mathrm{~m}$

the occurrence of specimens of Arkhangelskiella cymbiformis var. NT at $8.00 \mathrm{~m}$
\end{abstract}

Calcareous Nannoplankton: The samples analysed from this borehole yield nannofossil assemblages of moderate diversity, moderate preservation and moderate abundance.

The occurrence of Amphizygus brooksii, Broinsonia parca expansa, Cylindralithus biarcus, Lithastrinus grillii, Lucianorhabdus species, Micula staurophora, Zeugrhabdotus biperforatus, G. coronadventis and super abundant Watznaueria barnesae in the highest sample examined at $8.00 \mathrm{~m}$ is consistent with Seaford Chalk - Newhaven Chalk Formation; Splash Point - Haven Brow Beds sediment of Late - Middle Santonian, Subzone UC13i - Subzone UC11iii age.

The record of rare specimens A. cymbiformis var. NT from this sample, however, suggests an age as young as Subzone UC13i - Zone UC12; most probably within Subzone UC13i in the Late Santonian.

In comparison to the Seaford Head outcrop reference section, the absence/rarity of $H$. trabeculatus in this sample suggests a position above the Brasspoint Flint.

INTERVAL 9.00m - 11.00m:

MIDDLE SANTONIAN

Interval top and age based on:

the absence of Arkhangelskiella cymbiformis var. NT at, and below, $9.00 \mathrm{~m}$

Calcareous Nannoplankton: These samples remain characterised by the occurrence of Amphizygus brooksii, Broinsonia parca expansa, Cylindralithus biarcus, Lithastrinus grillii, Lucianorhabdus species, Micula staurophora, Zeugrhabdotus biperforatus, G. coronadventis and super abundant Watznaueria barnesae. This association is consistent with Seaford Chalk Formation, Haven Brow Beds sediment of Middle Santonian, Zone UC12 age.

The low abundances of Lucianorhabdus species, C. obscurus and M. staurophora point more towards the lower part of Zone UC12. 
In comparison to the Seaford Head outcrop, the absence/rarity of $H$. trabeculatus over this interval continues to suggest a position above the Brasspoint Flint.

SAMPLE 15.00m:

MIDDLE SANTONIAN

Sample age based on:

the last appearance datum (LAD) of Helicolithus trabeculatus at $15.00 \mathrm{~m}$

Calcareous Nannoplankton: The LAD of $H$. trabeculatus at $15.00 \mathrm{~m}$ suggests penetration of the equivalent of lower Haven Brow beds, Subzone UC1iii, above the equivalent level of the Brasspoint Flint in the Seaford Head section.

As this sample is positioned within the Third Main Phosphate Bed it is possible that the occurrence of H. trabeculatus is reworked in this sample.

INTERVAL 18.00m - 21.00m:

EARLY SANTONIAN

Interval top and age based on:

the increase abundance of Helicolithus trabeculatus at $18.00 \mathrm{~m}$

the LAD of Quadrum eptabrachium at $19.00 \mathrm{~m}$

Calcareous Nannoplankton: The increase in abundance of $H$. trabeculatus at $18.00 \mathrm{~m}$ suggests penetration of Seaford Chalk Formation; Haven Brow Beds sediments of Early Santonian; Subzone UC11iii age.

The LAD of $Q$. eptabrachium at $19.00 \mathrm{~m}$ also indicates penetration of Subzone UC11iii.

In comparison to the Seaford Head section, the moderate increase in abundance of $H$. trabeculatus at $18.00 \mathrm{~m}$ indicates a position immediately below the Brasspoint Flint and above the Flat Hill Flint (=Bedwell's Columnar).

The interval below the Third Main Phosphate Bed is clearly of a different age to that above. Somewhere within the phosphate interval is the equivalent of the Brasspoint Flint.

INTERVAL $22.00 \mathrm{~m}$ - 44.00m:

EARLY SANTONIAN - MIDDLE CONIACIAN

Interval top and age based on:

the further increase in abundance of Helicolithus trabeculatus at $22.00 \mathrm{~m}$

the FAD of consistent Q. eptabrachium at $26.00 \mathrm{~m}$ 


\author{
the FAD of Lithastrinus grillii at $42.00 \mathrm{~m}$ \\ the occurrence of rare, but inconsistent Calculites obscurus down to $42.00 \mathrm{~m}$ \\ the FAD of common $H$. trabeculatus at $44.00 \mathrm{~m}$
}

Calcareous Nannoplankton: The further increase in abundance of $H$. trabeculatus at $22.00 \mathrm{~m}$ suggests penetration of Seaford Chalk Formation; Haven Brow Beds sediments of 'earliest' Santonian; Subzone UC11ii age or older. The associated minor acme occurrence of C. ovalis is consistent with this age dating.

In comparison to the Seaford Head section, the further increase in abundance of $H$. trabeculatus at $22.00 \mathrm{~m}$ indicates a position immediately below the Flat Hill Flint (=Bedwell's Columnar) or older.

The abundance of nannofossils, $H$. trabeculatus in particular, is adversely affected by the occurrence of phosphatic intervals $27.00 \mathrm{~m}-29.00 \mathrm{~m}$ and $37.00 \mathrm{~m}-39.00 \mathrm{~m}$.

The $H$. trabeculatus nannofossil influx event is of proven correlative utility over a wide area of North West Europe, having been recognized at Seaford Head Sussex, Norfolk (Trunch Borehole), Germany (Lagerdorf) and in the North Sea Basin.

The minor increase in abundance of Broinsonia parca expansa at $25.00 \mathrm{~m}$ is very significant as it may be the highest nannofossil indicator for definite penetration of Late Coniacian sediments regionally (intra Subzone UC11ii). There is also a minor downhole increase in Q. eptabrachium at 26.00m.

H. trabeculatus remains a dominant assemblage component down to $45.50 \mathrm{~m}$; but is particularly abundant down to $44.00 \mathrm{~m}$, (just above the equivalent to the Cuckmere Sponge Bed in the Thames area).

INTERVAL 44.00m - 45.50m(l.s.e.):

\title{
MIDDLE CONIACIAN
}

Interval top and age based on:
the highest occurrence of relatively common $Q$. eptabrachium at $44.00 \mathrm{~m}$
the last downhole occurrence of abundant $H$. trabeculatus at $44.00 \mathrm{~m}$
the occurrence of common $M$. staurophora in the last sample examined at $45.50 \mathrm{~m}$.

Calcareous Nannoplankton: The highest occurrence of moderately common Q. eptabrachium $(44.00 \mathrm{~m})$ is consistent with penetration of Middle Coniacian age sediment (Subzone UC10i); this event is recorded just below the Cuckmere Sponge Bed in the Seaford Head section in Sussex.

The last downhole occurrence of abundant $H$. trabeculatus is also noted at $44.00 \mathrm{~m}$. This event was also recognized in the Seaford Head section in Sussex a few metres above the Seven Sisters Flint Band. Perhaps the $100 \mathrm{~mm}$ Flint Band at $43.2 \mathrm{~m}$ is Cuckmere $2 / 1$ or Seven Sisters? 
The occurrence of common M. staurophora in the lowest sample analysed $(45.50 \mathrm{~m})$ in this borehole indicates an age not older than Subzone UC10i in the Middle Coniacian. M. staurophora is recorded from as low as Belle Tout Marl 2 in the Seaford Head Section of Sussex, but ranges lower still. 


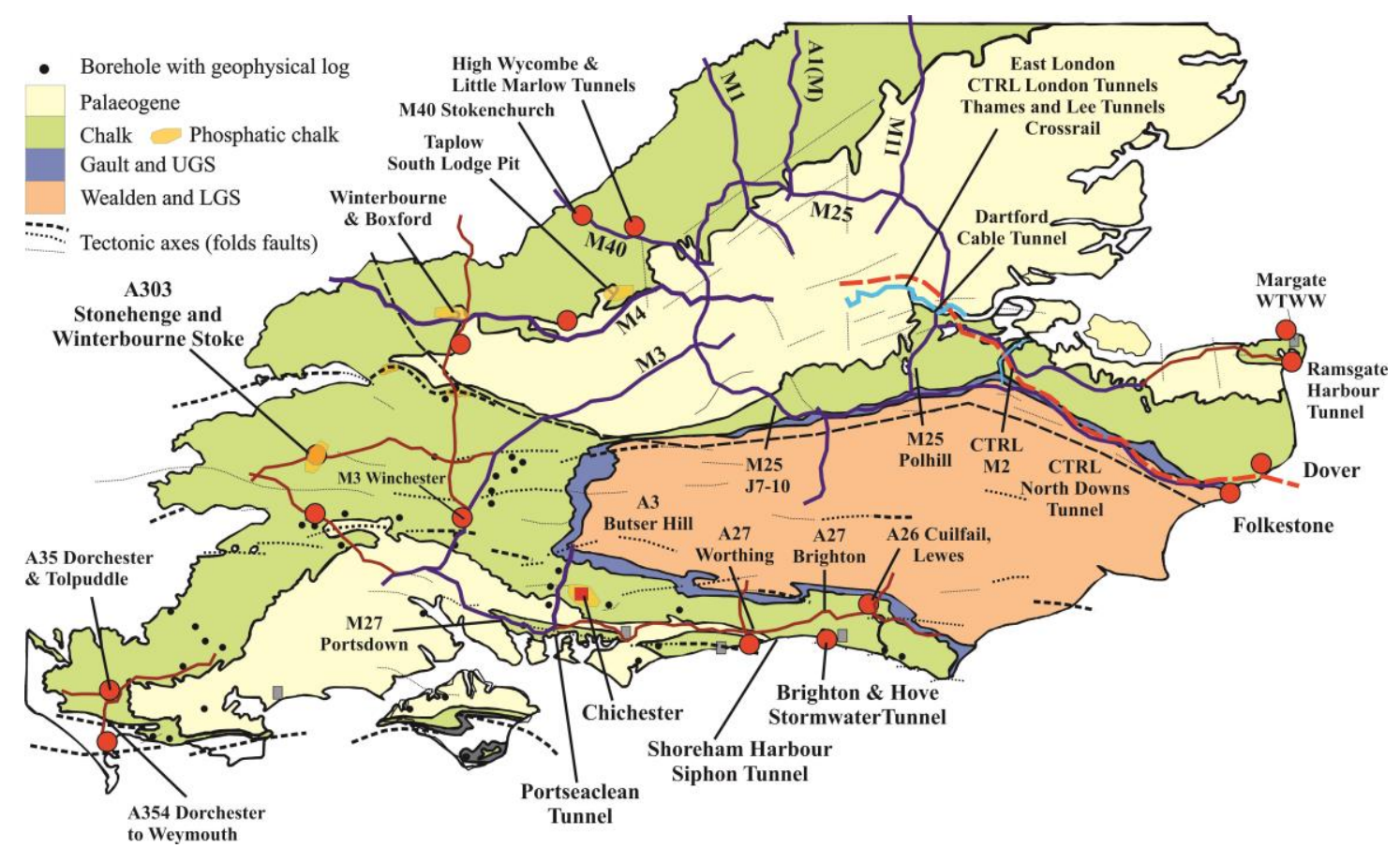

Figure 1. Location of the A303 Stonehenge investigations in relation to southern England geology and other major Chalk engineering schemes.

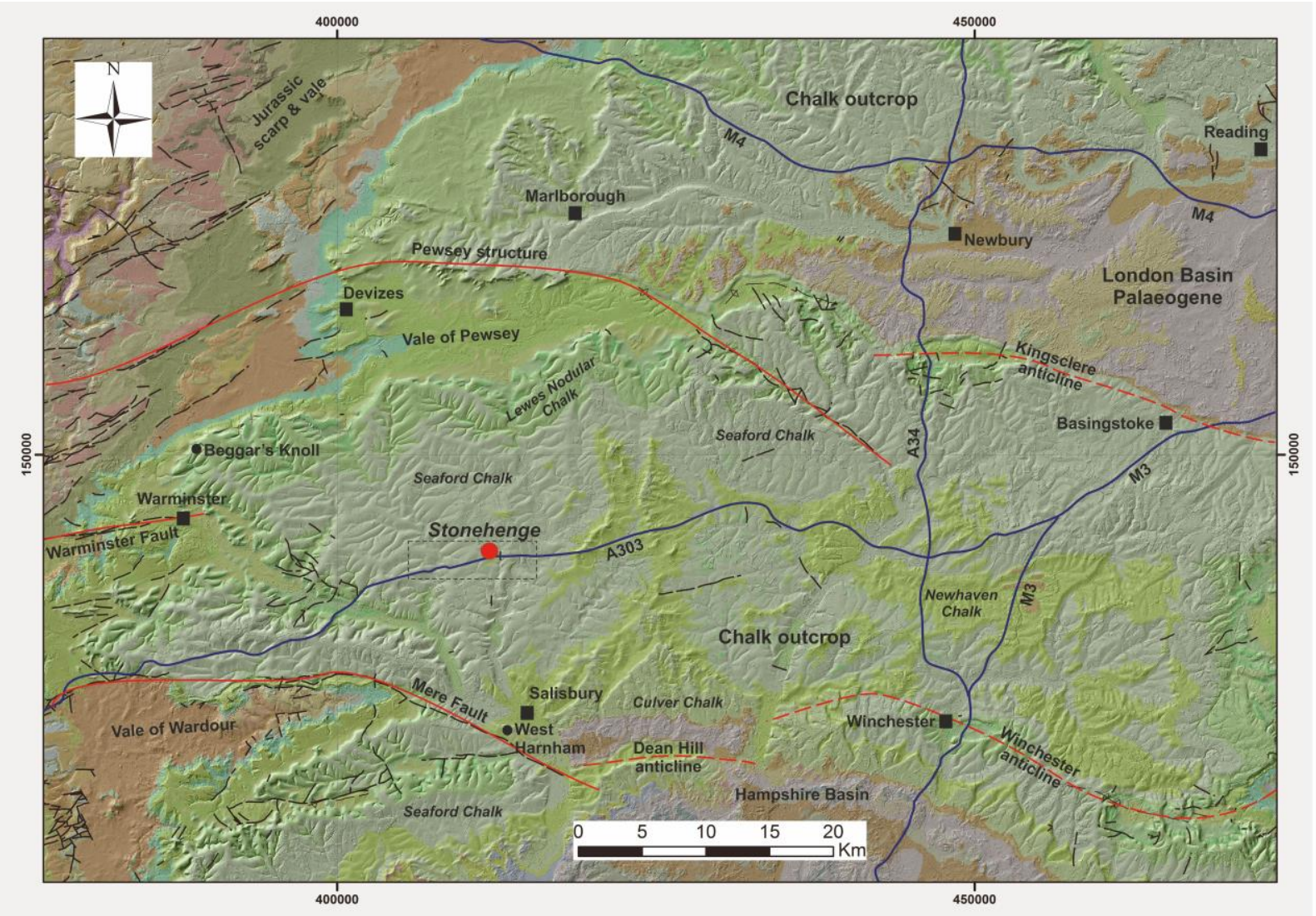

Figure 2. The A303 Stonehenge site is located on the southern edge of Salisbury Plain where there are few Chalk exposures. The green colours are the different Chalk Formations and the Upper Greensand (as mapped by BGS). The major geological structures are shown. The area covered by the road scheme is shown by the dashed box. The geological data is derived from BGS Digmap 1:50,000 scale data draped over NEXTMapTM Britain elevation data from Intermap Technologies. 


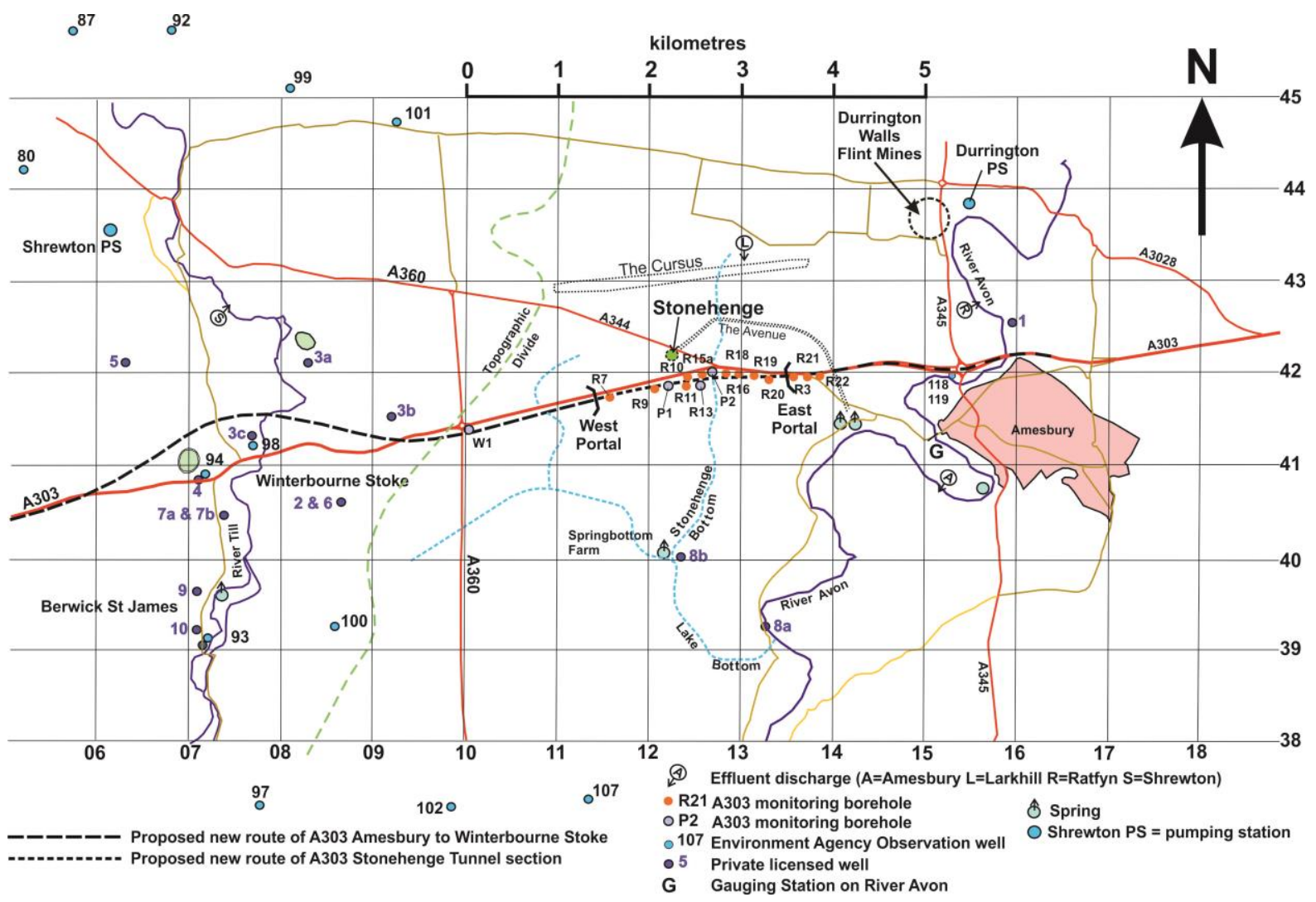

Figure 3. The Stonehenge Tunnel ground investigation boreholes and trial pits form part of the wider A303 Amesbury-Winterbourne Stoke improvements (2002 layout). The investigations included a review of all groundwater monitoring boreholes in the area (modified from Mortimore, 2012). The line of section (Figure 5) follows the dashed line of the then (2002) proposed new route of the A303. 

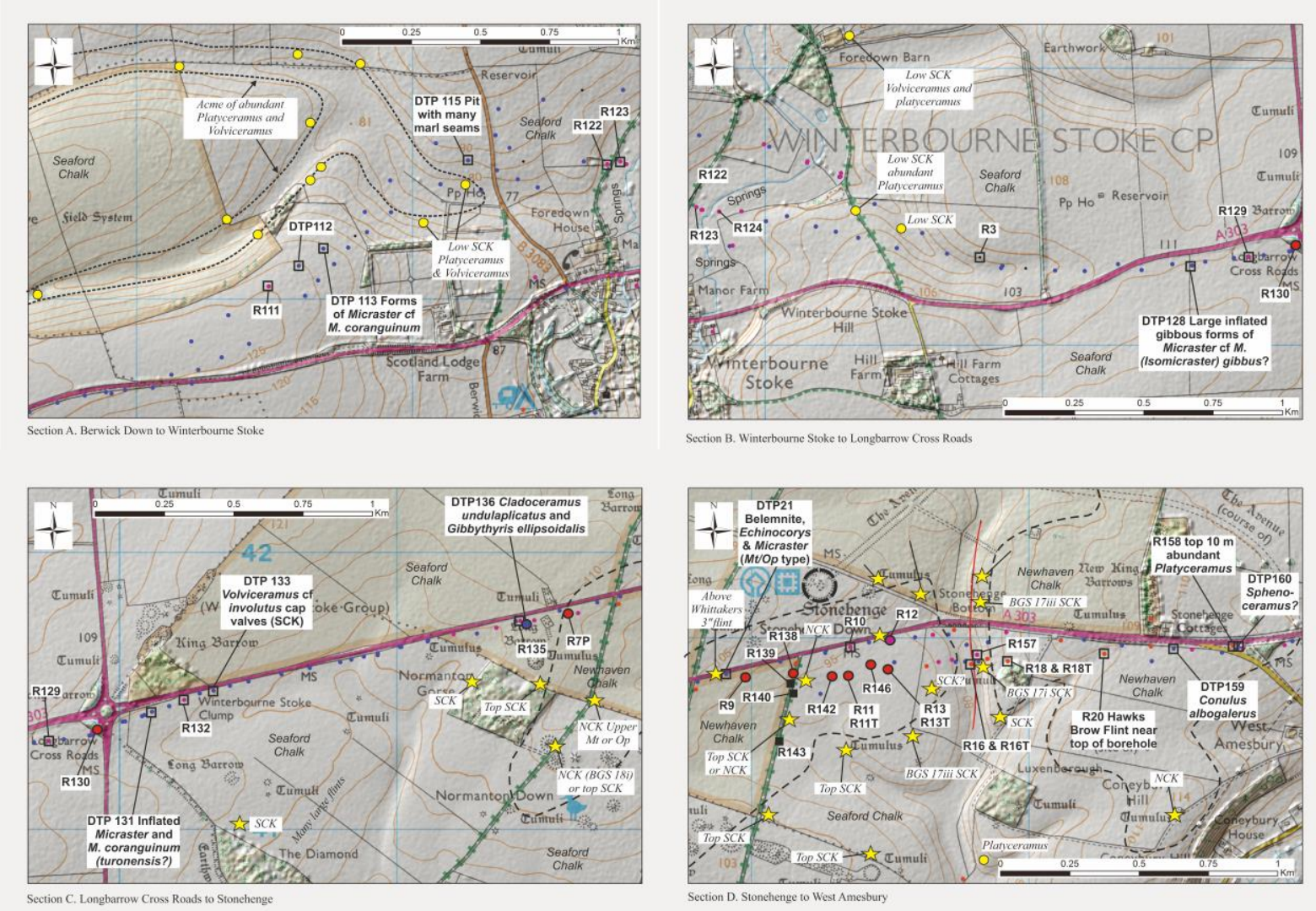

- Site Investigation borehole $>30 \mathrm{~m}$ deep
- Site Investigation borehole $10-30 \mathrm{~m}$ deep

- Site Investigation borehole or trial pit 0-10 $\mathrm{m}$ deep

Rotary borehole $>30 \mathrm{~m}$ deep logged stratigraphically with phosphatic chalk

- Rotary borehole $10-30 \mathrm{~m}$ deep logged stratigraphically with phosphatic chalk

- Rotary borehole or Trial Pit 0-10 $\mathrm{m}$ deep logged stratigraphically with phosphatic chalk

Q Rotary borehole or Trial Pit with stratigraphic evidence, but no phosphatic chalk.

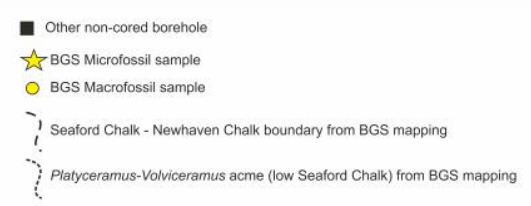

Figure 4. Location of the 2001 and 2002 A303 Stonehenge ground investigation boreholes and trial pits (with macro-fossils) with British Geological Survey (BGS) field localities (yellow stars) added. SCK = Seaford Chalk, NCK = Newhaven Chalk. This combined information is used to construct the Chalk stratigraphy in the area and the map and longsection Figure 6. The dashed line is the boundary between the Seaford and Newhaven Chalk formations. Contains Ordnance Data ( C Crown Copyright and database rights 2016 and NEXTMap Britain elevation data from Intermap Technologies'. 


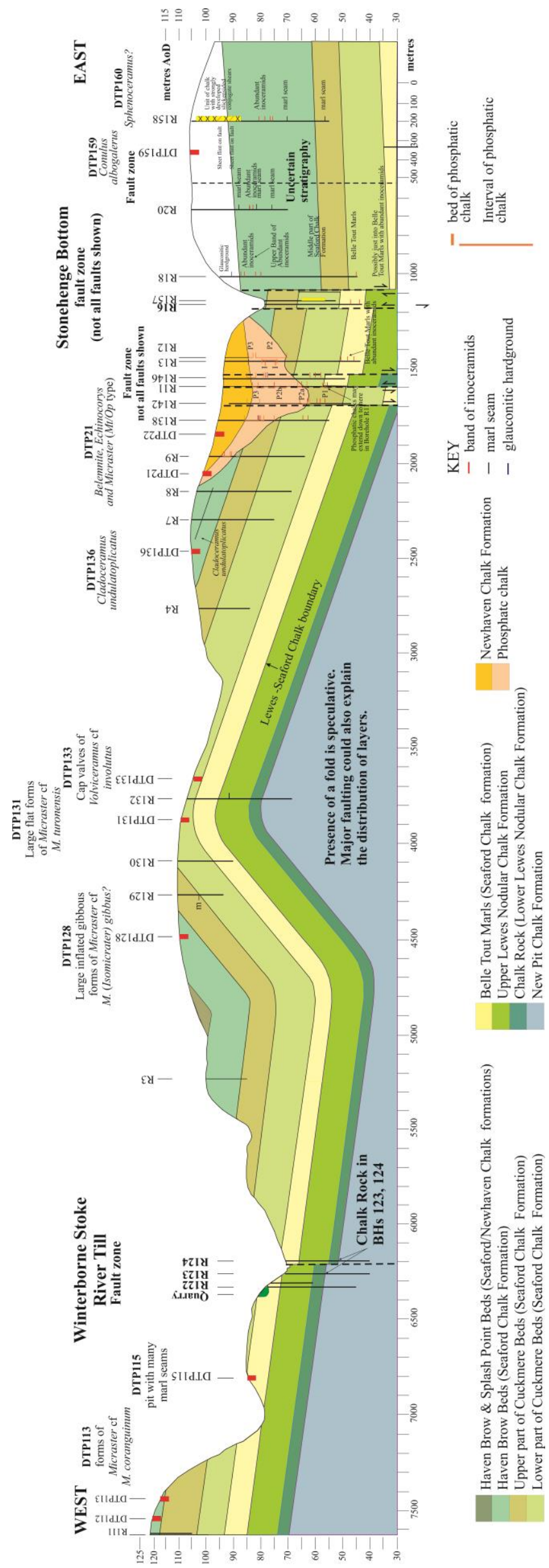

Figure 5. Schematic geological section along the A303 Stonehenge and Winterborne Stoke bypasses (Amesbury-Berwick Down) based on 1:2500 scale plans from the main site investigation Mott Macdonald 57334/UWG/CRO/1001/1002/1003. Horizontal scale and ground profile are taken from a mean line between SI boreholes and trial pits. The geological structure (dip and faults) is the best interpretation based on the on the lithological and palaeontological information obtained from boreholes and trial pits. Changes in dip/folding are partly an artefact of change in direction of the line of section, the dashed line for the proposed route in Figure 3. The phosphatic-chalks are located west of Stonehenge Bottom and are shown schematically as one large channel. In reality there are several channels (see figures 15-17) and many more faults. Note the faulted valleys of the River Till and Stonehenge Bottom. 

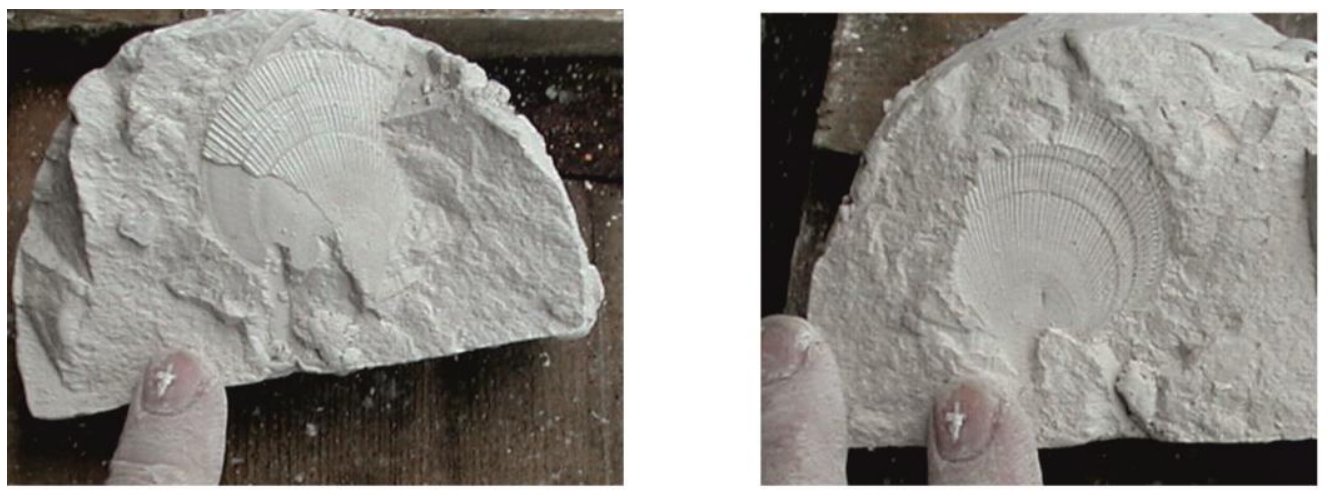

Bivalves form Stonehenge Borehole 138 core depth $18.20 \mathrm{~m}$ (i.e. below the phosphates): Mimachlamys cf cretosa (Delfrance) typical of $M$. coranguinum Zone and

G. quadrata Zone of East Harnham, near Salisbury,Wiltshire (i.e. Seaford and Newhaven Chalk formations)
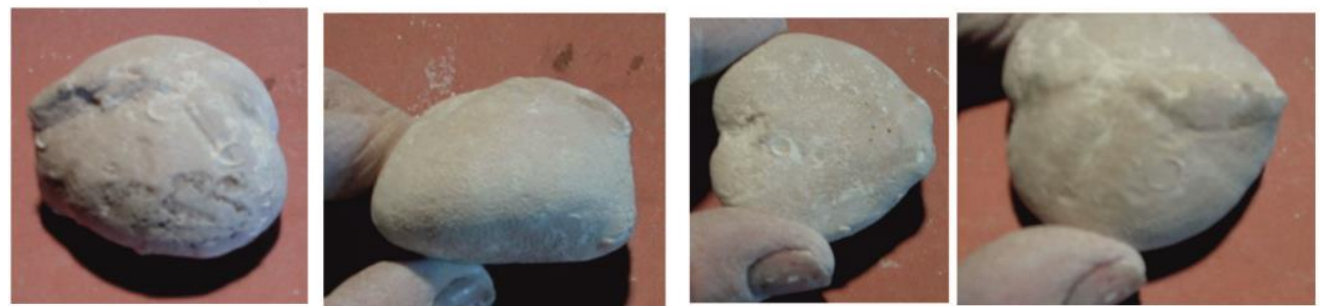

Micraster rogale from Late Santonian Newhaven Chalk (Splash Point Beds) Trial Pit DTP21
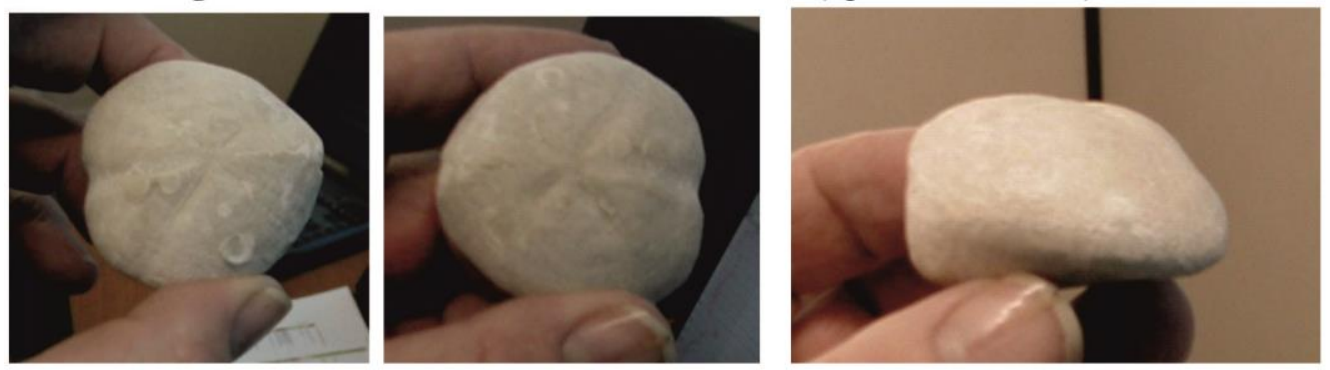

Micraster coranguinum (Leske) from Trial Pit 113 at 4-5 m depth Seaford Chalk Formation
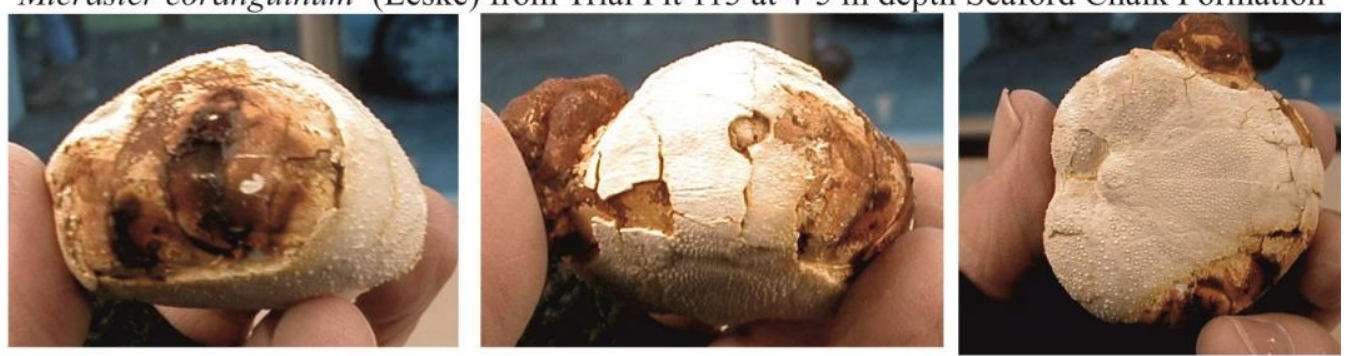

Inflated variety of Micraster $\mathrm{cf} M$. gibbus (Lamarck) with limonitised iron pyrites from Trial Pit 128, Haven Brow Beds, Seaford Chalk Formation

Micraster turonensis (large, flat 'cakes') from Chalk Trial Pit 131, Middle Coniacian, Cuckmere Beds, Seaford Chalk Formation
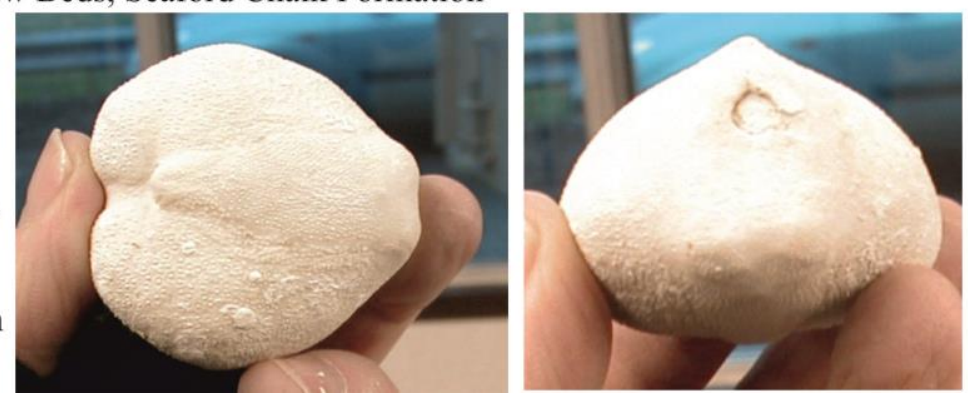

Figure 6. Some of the macrofossils from the A303 Stonehenge investigation trial pits and boreholes used to establish the stratigraphy. No fossils were retained so only site photographs taken at the time by RNM are available. 


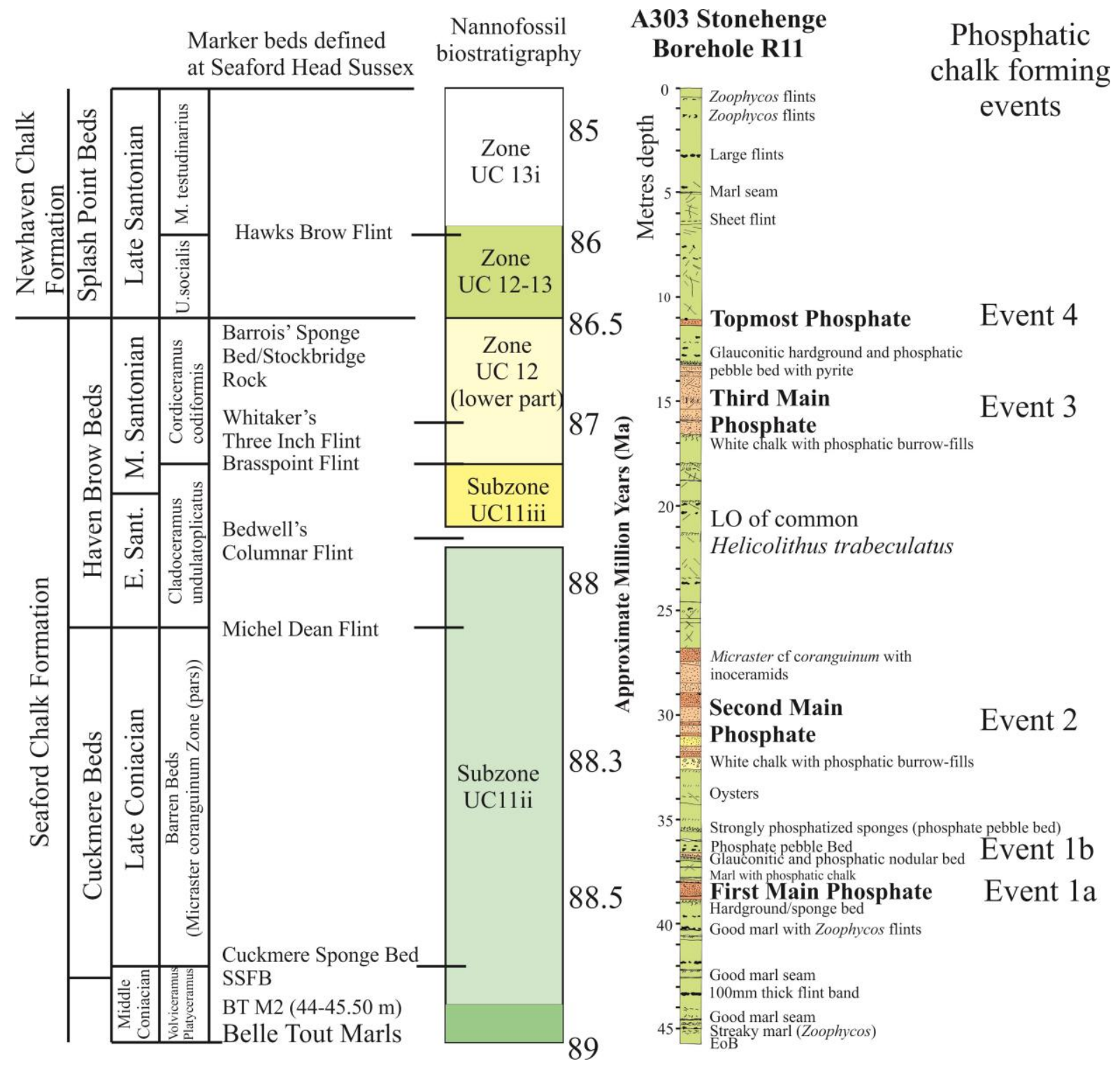

Figure 7. Borehole R11, containing several phosphatic-chalk horizons, is used as the standard borehole to date the deposits accurately using lithological marker beds and nannofossil biostratigraphy based on the Seaford Head, Sussex, standard section (Hampton et al., 2007). Four main phosphatic-chalk horizons are recognised at Stonehenge in 2 million years (Events $1-4)$. 


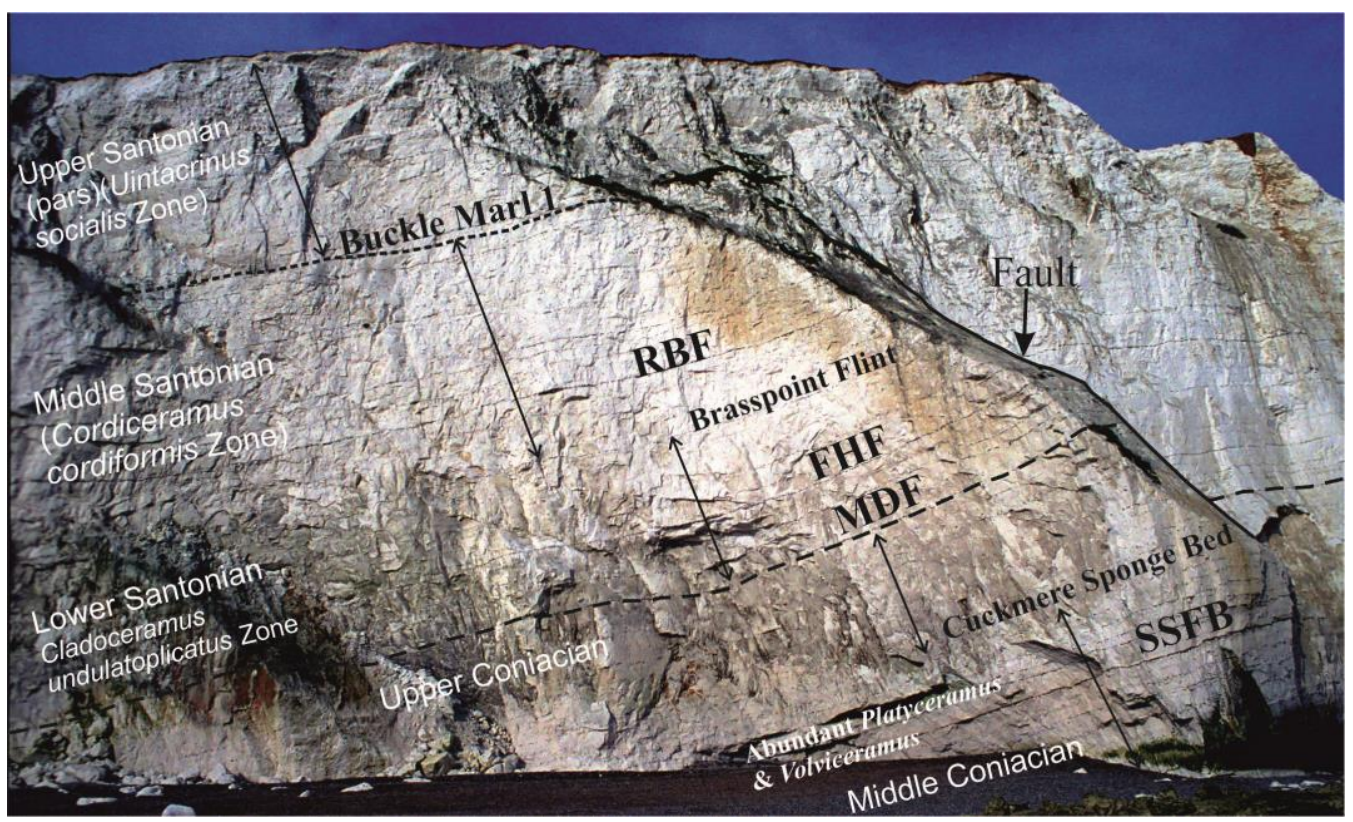

Figure 8a. Seaford Head Sussex provides the standard Chalk stratigraphy for the Chalk present at Stonehenge, without the phosphatic-chalks. The lithological marker beds, macrofossil biostratigraphy and nannofossil biostratigraphy developed at Seaford Head (Mortimore, 1986; Hampton et al., 2007) has been applied to the Stonehenge investigations. SSFB=Seven Sisters Flint Band; MDF= Michel Dean Flint; FHF=Flat Hill Flint; RBF=Rough Brow Flint BM1=Buckle Marl 1 at the base of the Newhaven Chalk Formation

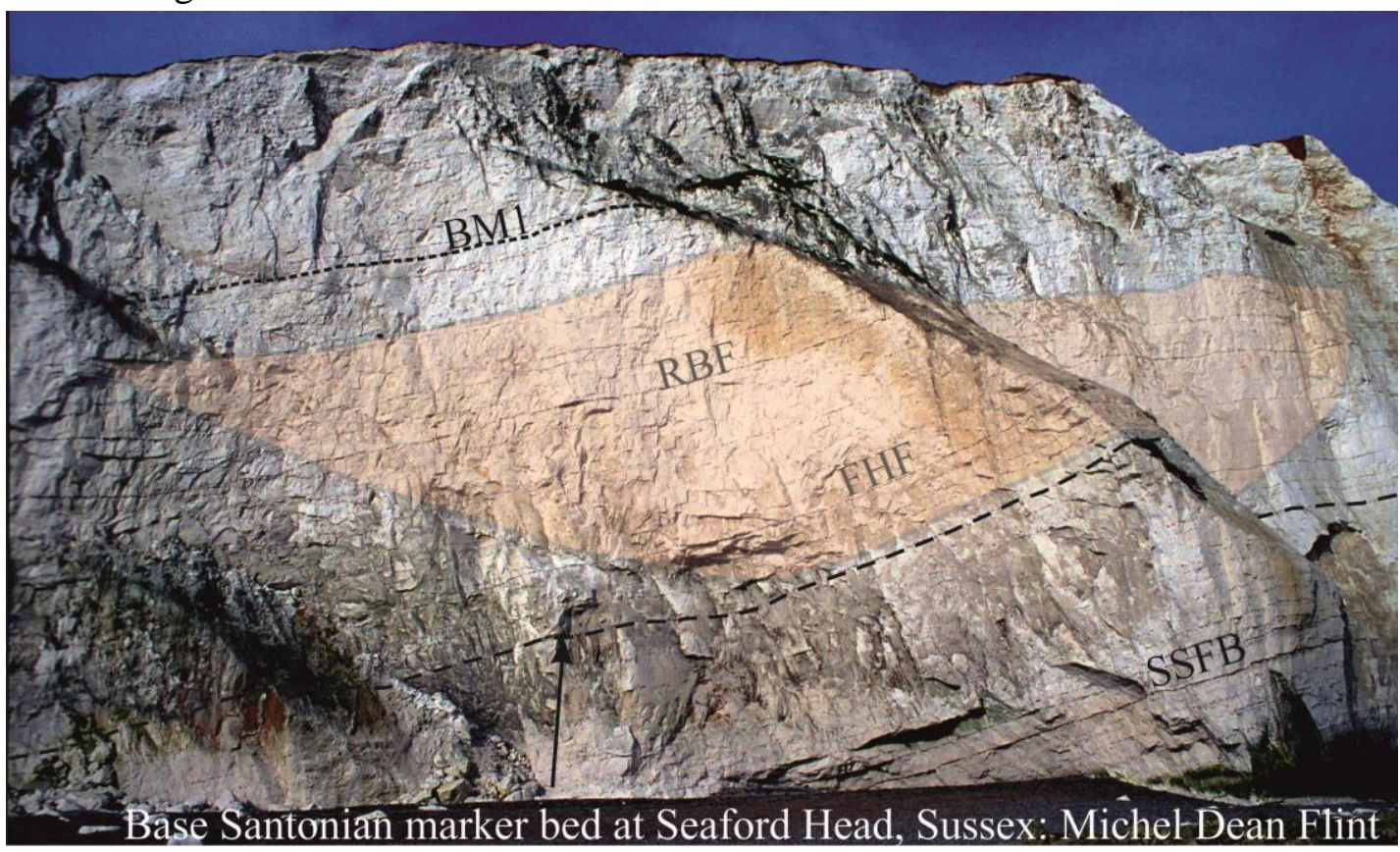

Figure $8 \mathrm{~b}$. Schematic view of the scale of the Stonehenge main phosphatic chalk channel ( $3^{\text {rd }}$ Main Phosphatic Chalk Event), superimposed on the Seaford Head field section illustrating how much Seaford Chalk has potentially been eroded away at Stonehenge during Event 3. 


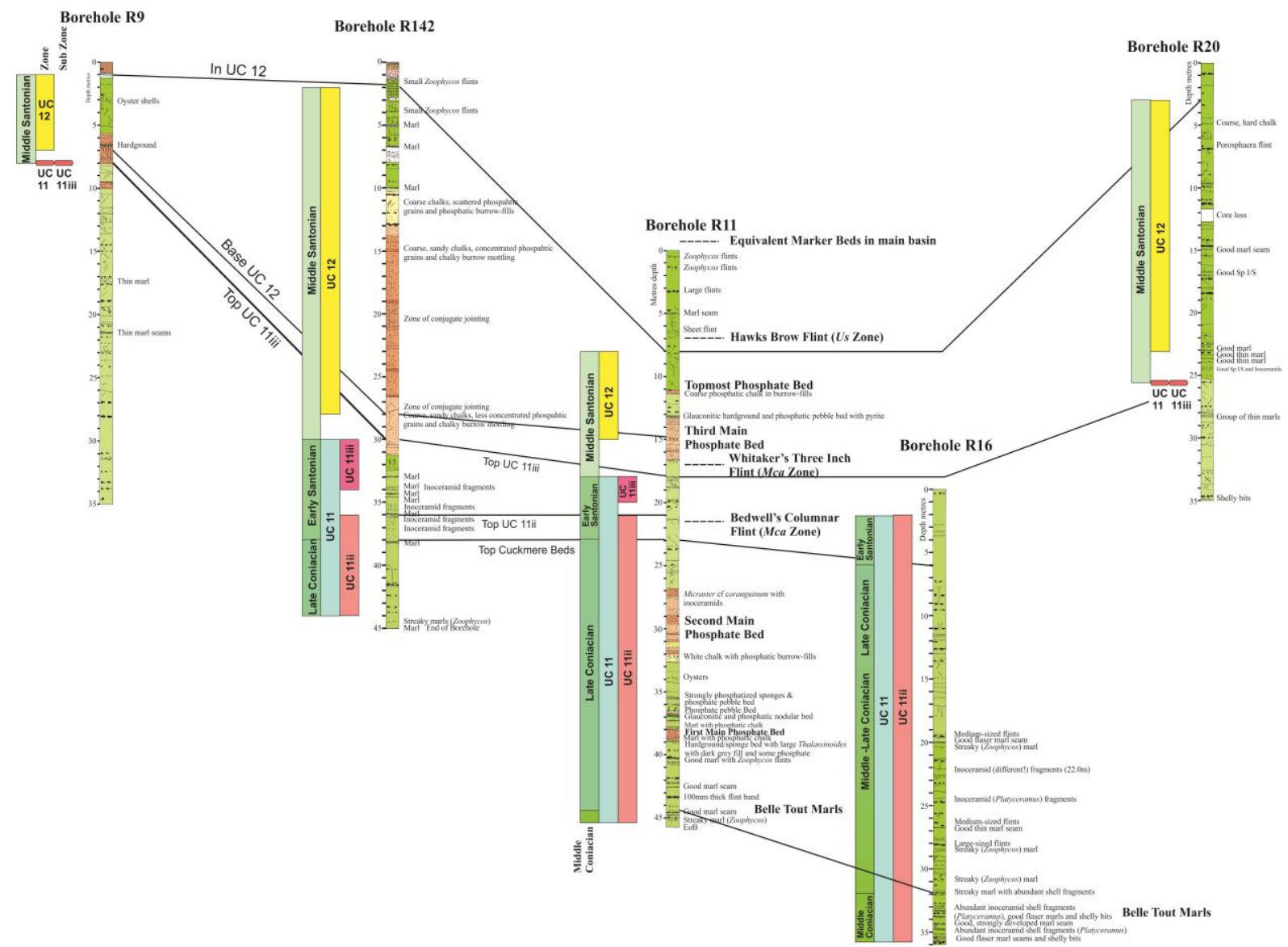

Figure 9. Correlation of five cored boreholes (R9, R142, R11, R16, R20) from the A303 Stonehenge Tunnels investigation using nannofossil biostratigraphy. 


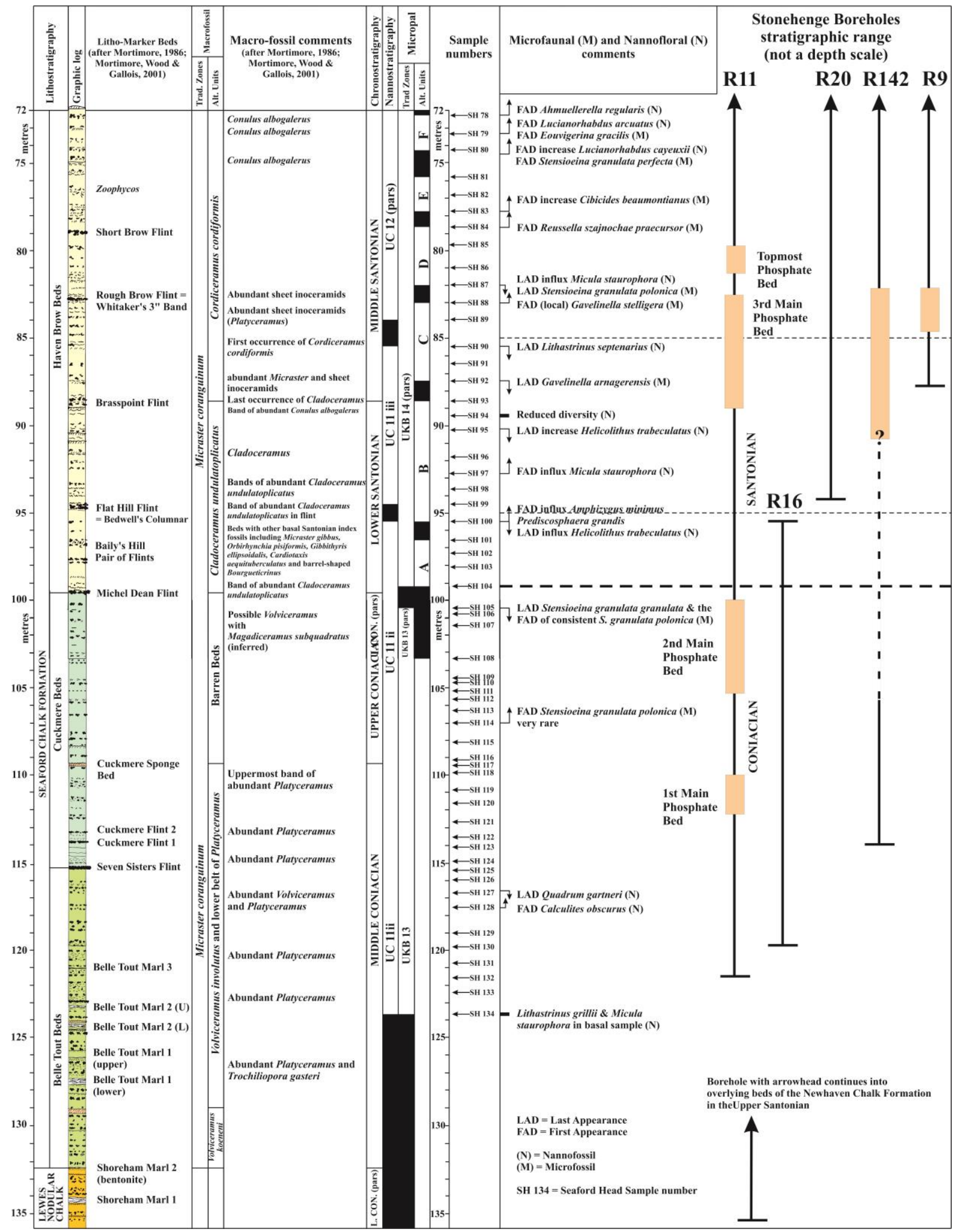

Figure 10. Stratigraphical position of boreholes R9, R142, R11, R16, R20 with phosphatic chalk based on nannofossil biostratigraphy, plotted against the standard Seaford Head, Sussex field section (Figure 8). Phosphatic chalk intervals are shown schematically as these are probably erosional events with channels and re-working of nannofossils and hence stratigraphical range of the coloured blocks needs careful interpretation. 

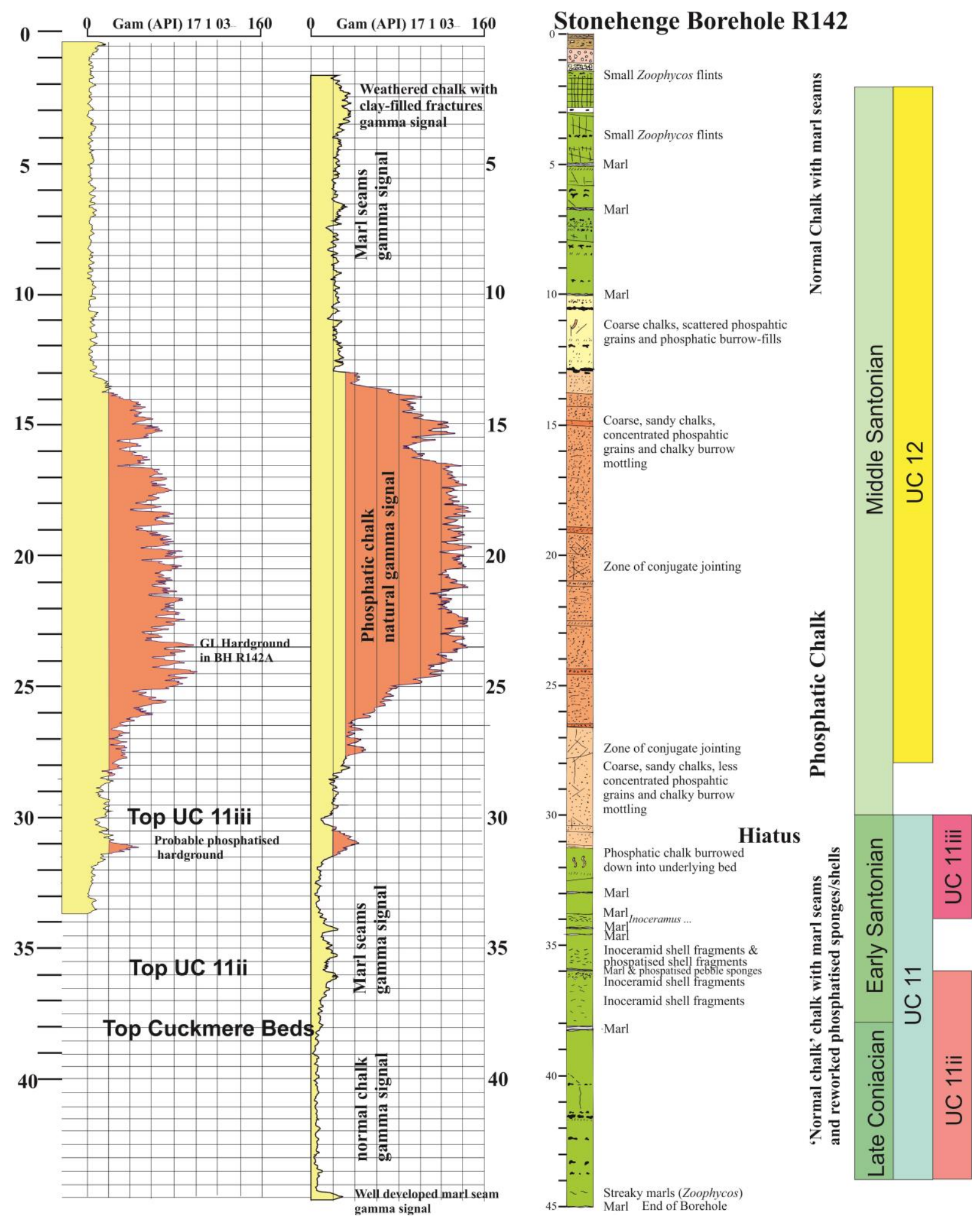

Figure 11. Borehole R142 and R142A natural gamma geophysical borehole logs and R142 core-log for the thickest phosphatic-chalks so far found at Stonehenge showing the stratigraphical results from the nannofossil biostratigraphy (UC11ii to UC12, standard nannofossil zones for the Upper Cretaceous). This very thick phosphatic-chalk deposit represents Event 3 (Figure 7) with the basal 'erosion?' surface cutting down into underlying chalk, probably removing earlier events (reworked nannofossils in the phosphatic chalk). 


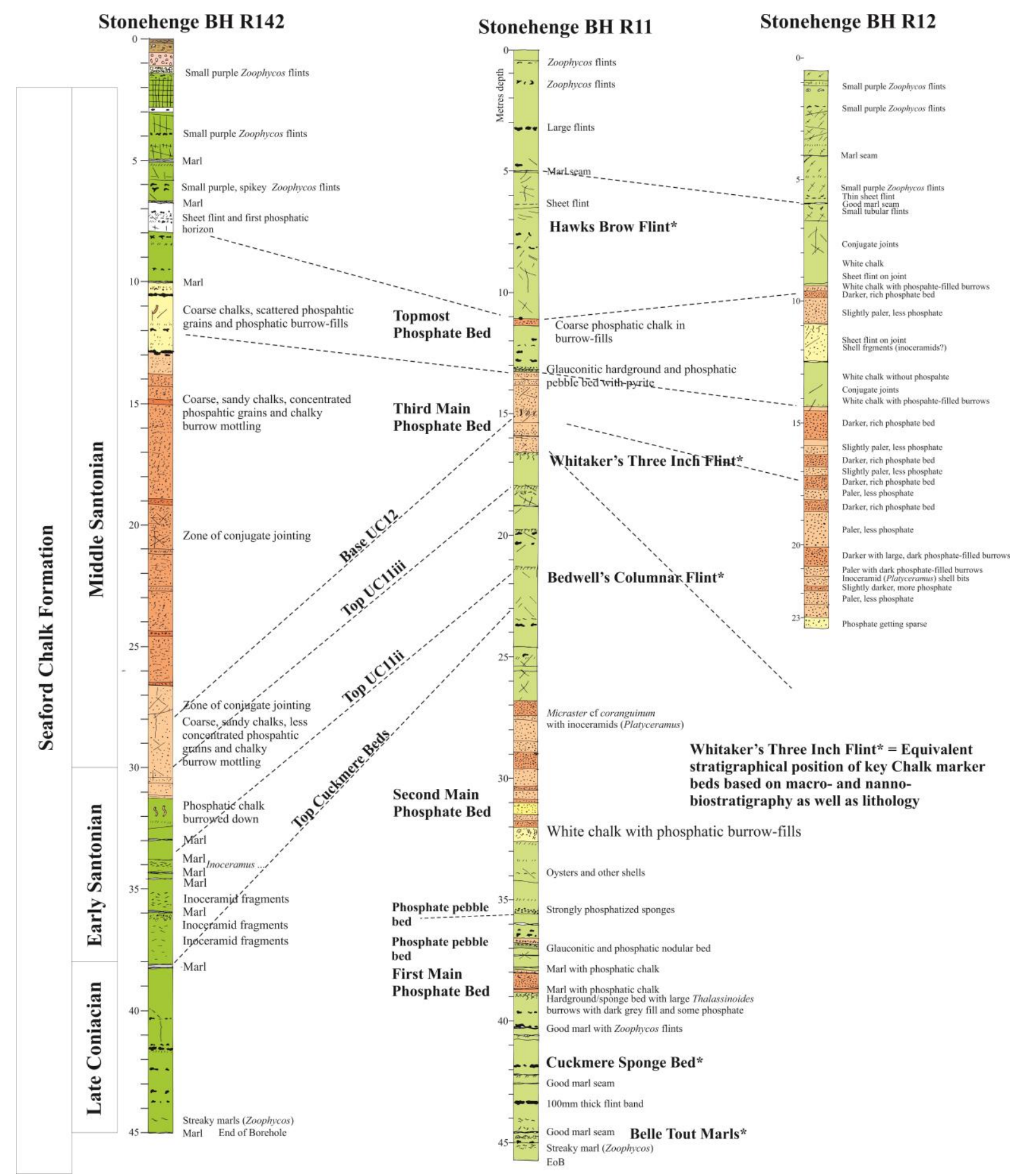

Figure 12. Correlation of the thickest phosphatic-chalks found in Borehole R142 with the standard Borehole R11 which contains all the so far known phosphatic-chalk events found at Stonehenge. The nannofossil biostratigraphy (UC11ii to UC12) for boreholes R11 and R142 illustrates that the very thick phosphatic-chalk deposit represents Event 3 in the Middle Santonian (Haven Brow Beds of the Seaford Chalk Formation) with the basal 'erosion?' surface cutting down into underlying chalk, probably removing earlier events. No nannobiostratigraphic analyses have been undertaken on the cores from BHR12 which also contains a very thick phosphatic-chalk deposit. The correlation lines presume that this second thick phosphatic-chalk succession in BHR12 equates with the similar thickness deposit in Borehole R142. 


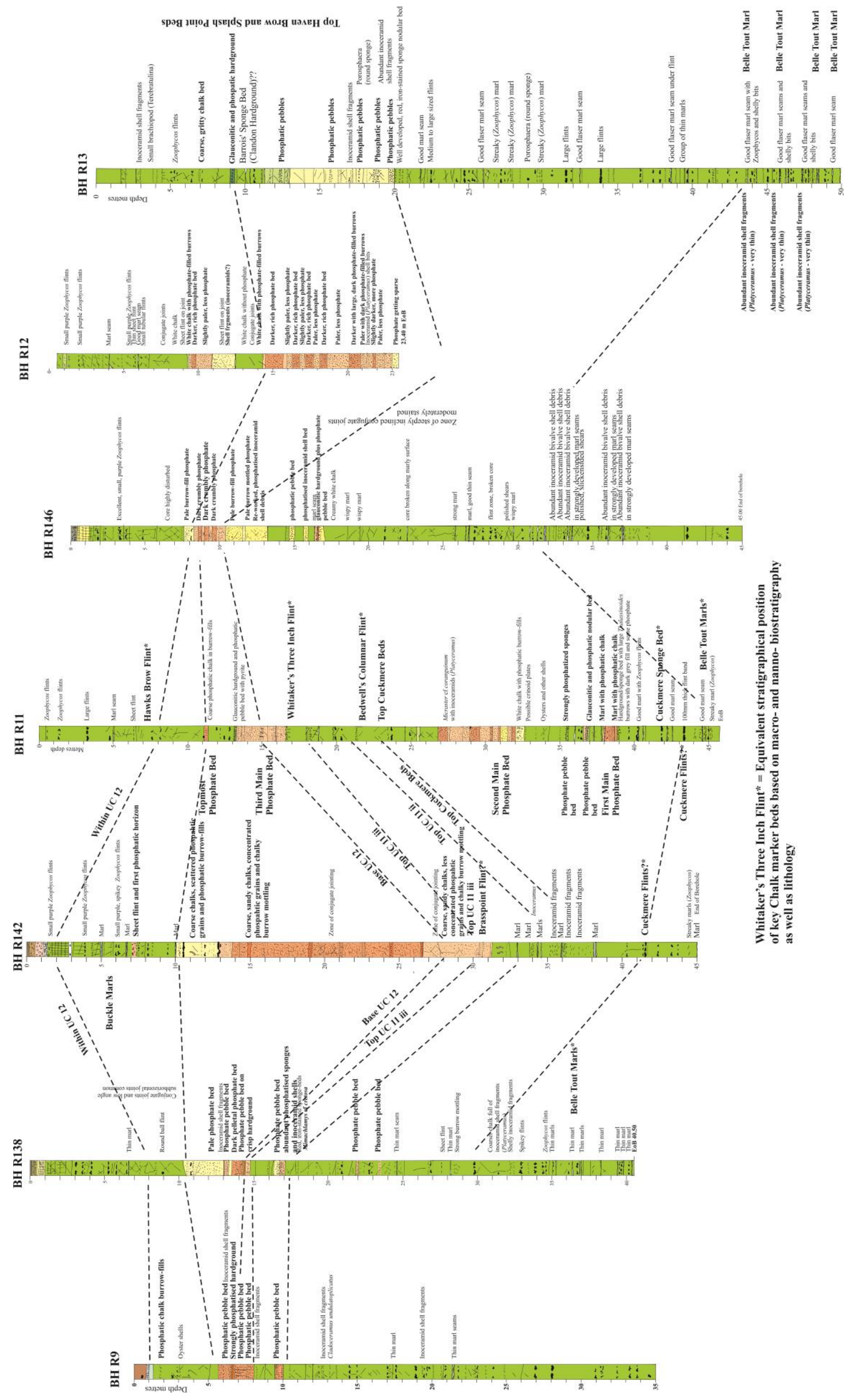


Figure 13. Correlation of A303 Stonehenge Tunnel boreholes containing phosphatic chalks. The deeper boreholes such as R11 and R13 have the Belle Tout Marls with associated Platyceramus and Volviceramus bivalve fossil shells beneath the phosphatic-chalk deposits in the Belle Tout Beds at the base of the Seaford Chalk Formation.

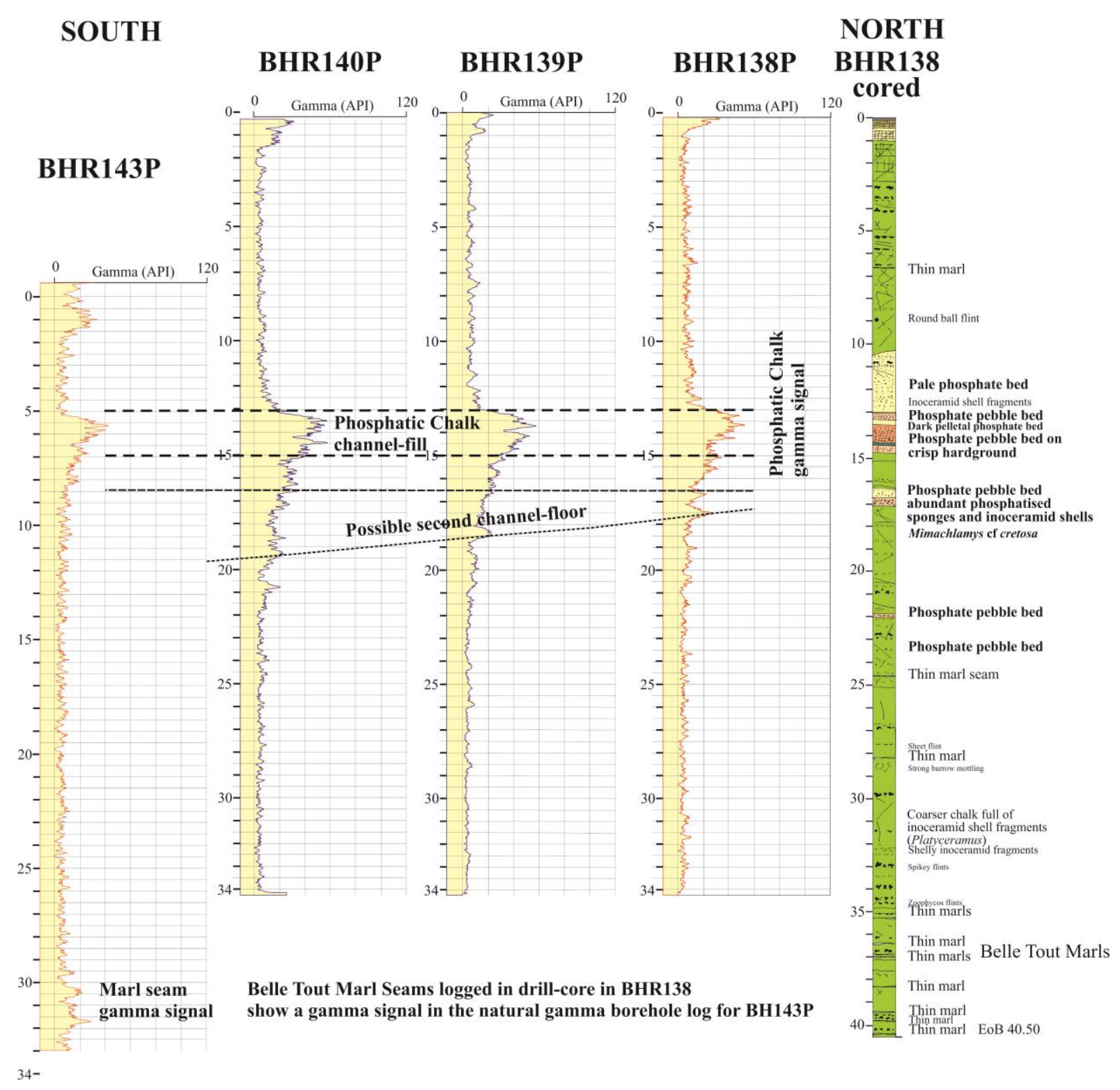

Figure 14a. A series of natural gamma geophysical logs from boreholes in a north-south line (see Figure 15) show the continuity of one of the phosphatic-chalk horizons (Third Main Phosphate Bed, Figure 8) and the northerly trend of the channel-fill. 
$93.10 \mathrm{~m} \mathrm{AoD}$

BHR13P

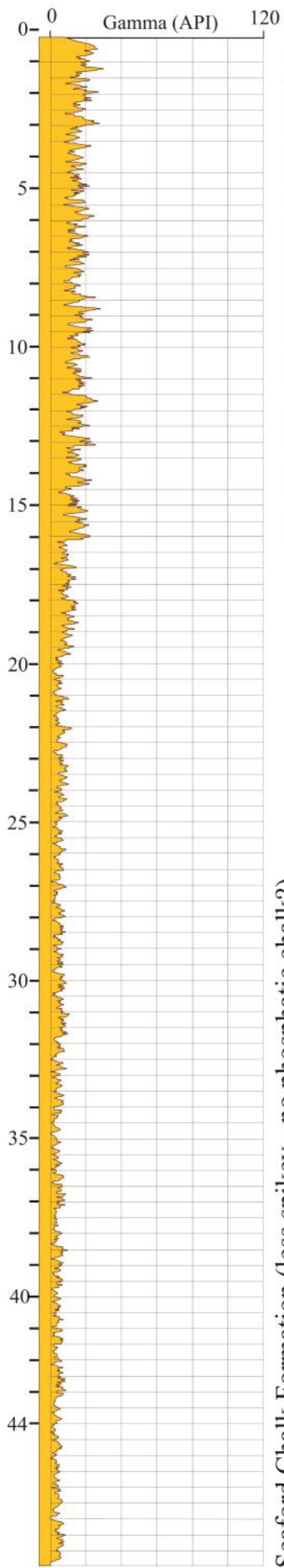

\section{BH R13 cored}

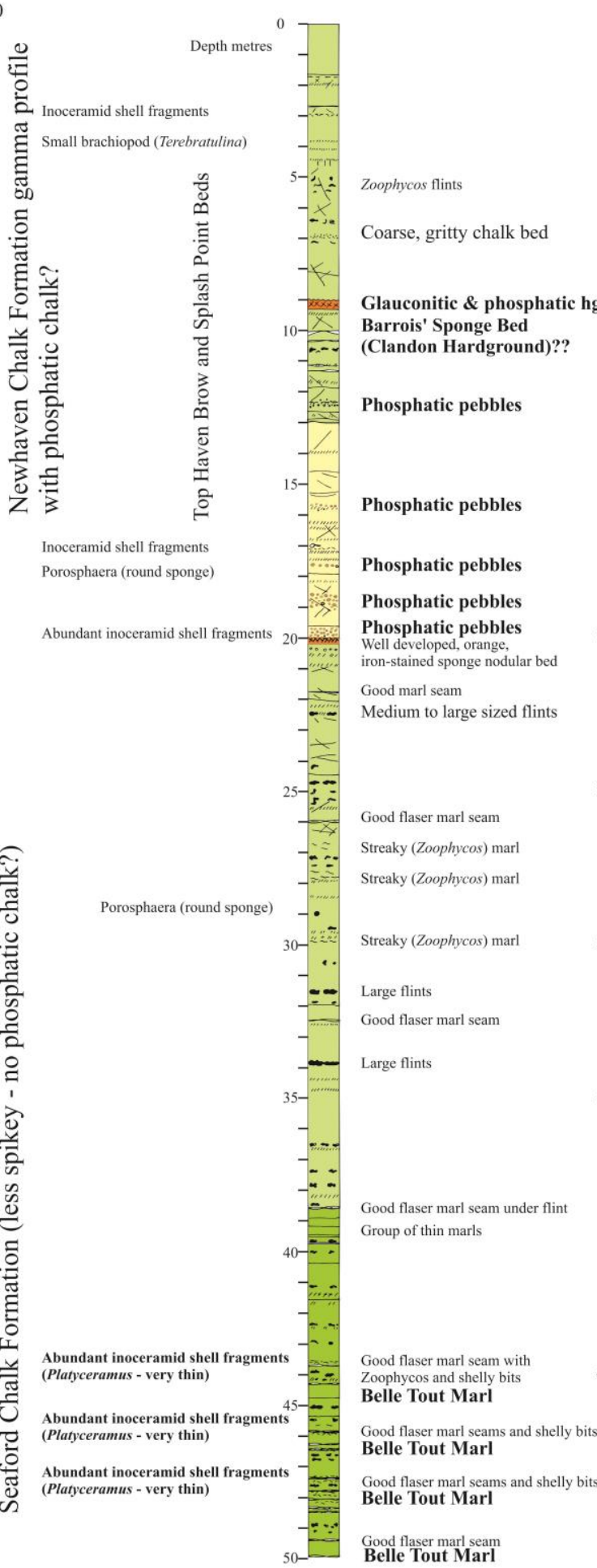

$90.80 \mathrm{~m} \mathrm{AoD}$

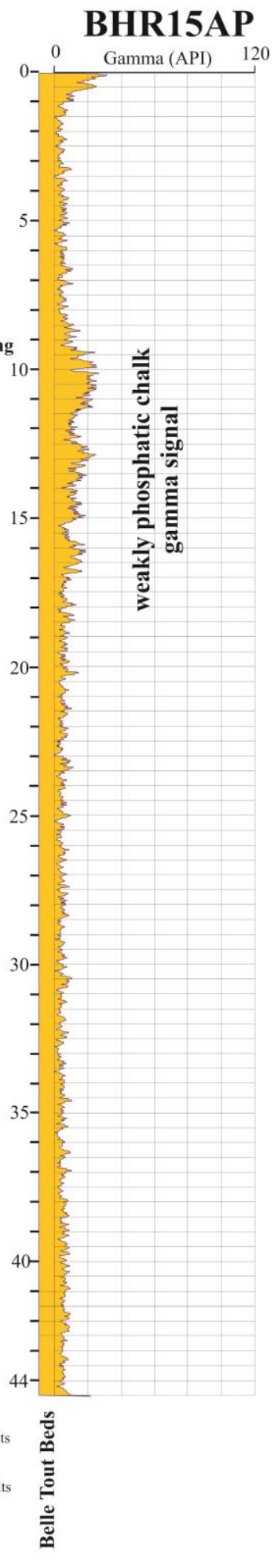

Figure 14b. Natural gamma geophysical logs for boreholes on the eastern side of the phosphatic chalks at Stonehenge. Borehole 13 is south of the borehole R12 with the second thickest phosphatic chalks (Figure 15). Borehole R15AP is further east and the natural gamma signal compares closely with the interval with weakly developed phosphatic chalks and phosphatic chalk pebble beds found in the cored borehole R13. 


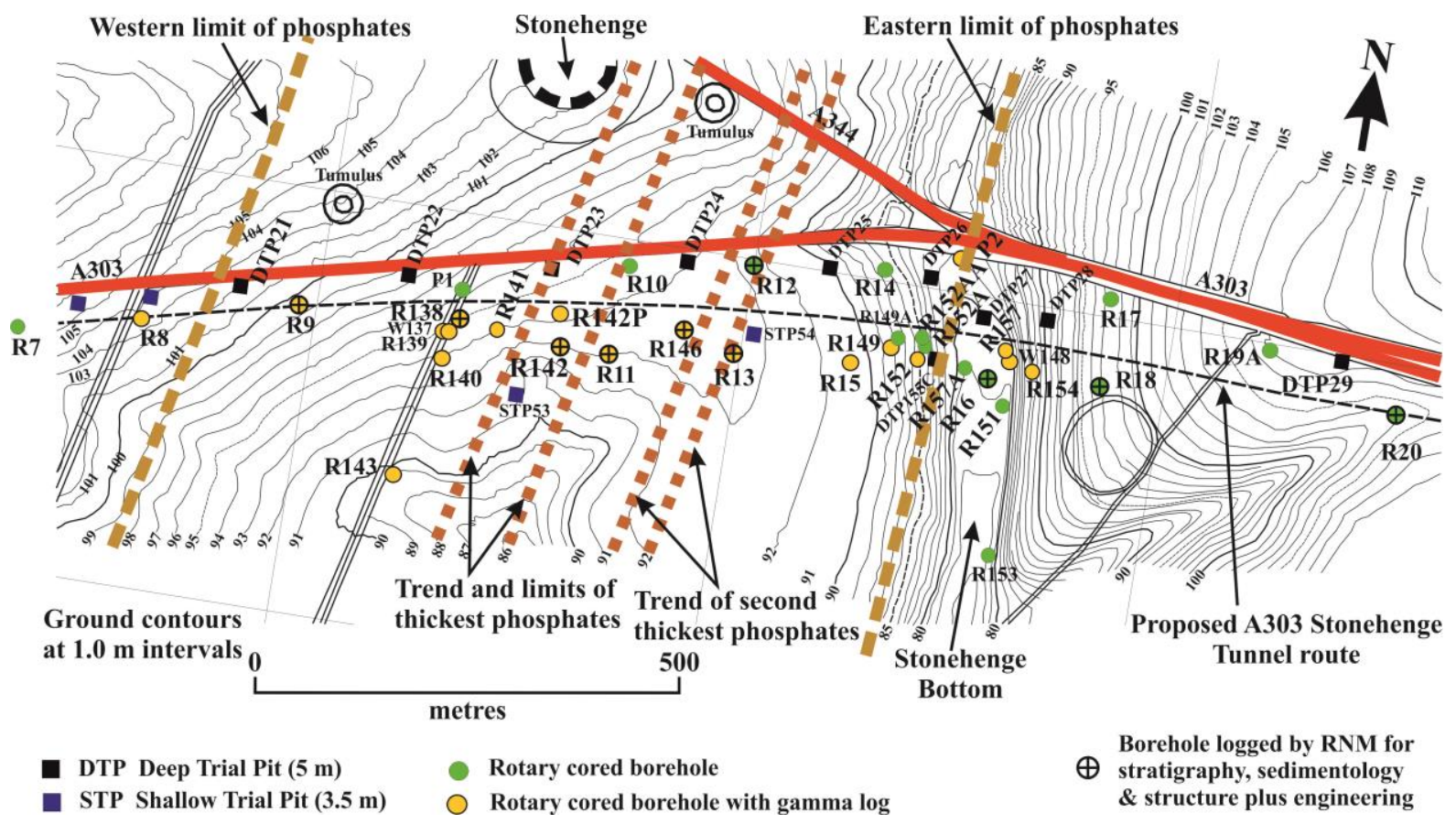

Figure 15. Map of the proposed A303 Stonehenge Tunnel route showing the position of key boreholes and the trend and position of phosphatic-chalk channels (modified from Mortimore, 2012).

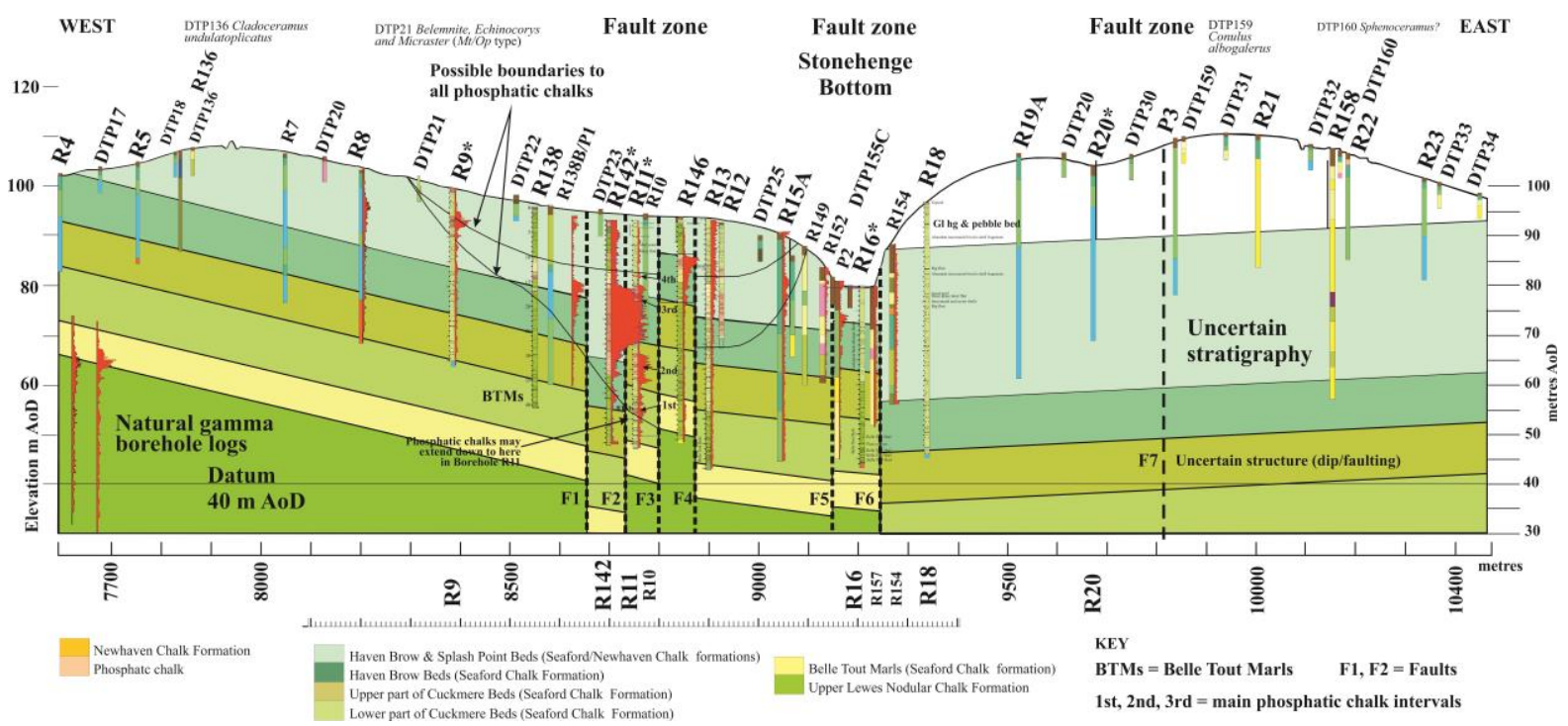

Figure 16a. The control boreholes used to establish the stratigraphical position and thicknesses of the chalk beds and the phosphatic chalks. Fully-cored boreholes R9, R142, R11, R16 and R20 have been biostratigrpahically analysed for macro- and nannofossils and provide the controls for recognising bed displacements caused by faults and the stratigraphical position of the phosphatic-chalks. In addition, other boreholes with Natural Gamma geophysical logs (red spiky profiles), show where phosphatic-chalks are present. 


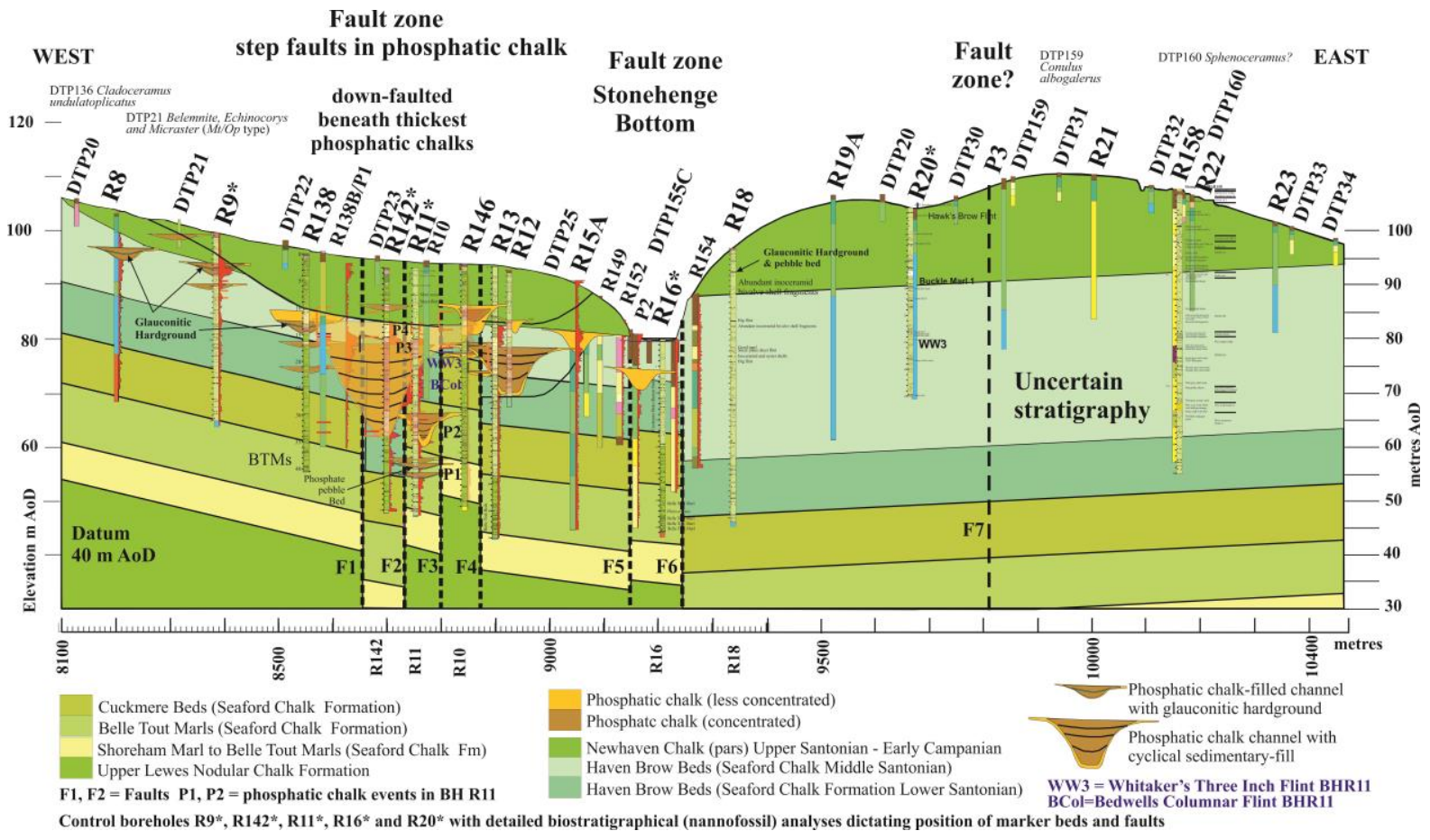

Figure 16b. Sedimentary model 1: A multichannel interpretation for the Stonehenge phosphatic chalks constructed from boreholes and trial pits showing the zones of north-south faulting defining the eastern limit of the channels (no phosphatic-chalks east of Stonehenge Bottom). The geological section shows the location of the two largest channels and 18 smaller ones in a complex fault zone (Modified from Mortimore, 2011, 2014). The thickest deposits are located in a down-faulted area between faults F1 and F2)

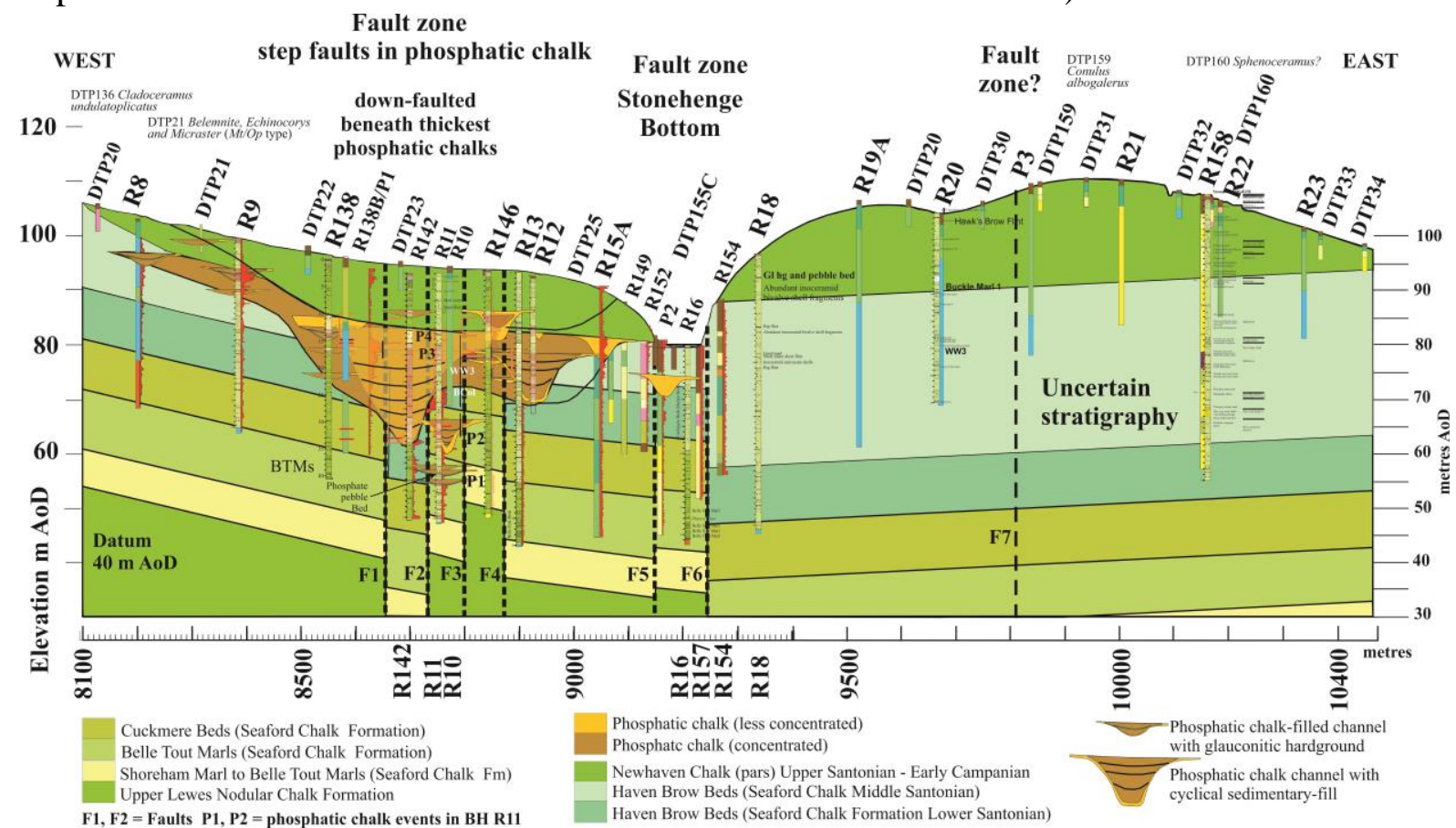

Figure 16c. Sedimentary model 2: A single major channel interpretation for the Stonehenge phosphatic-chalks linking the thickest deposits with fewer smaller ones. The large channel incorporates phosphatic-chalk Event 3 (P3) in BHR11 and R142 and is presumed to 
incorporate the thick phosphatic-chalks in BHR12. Earlier phosphatic-chalk Events P1 and $\mathrm{P} 2$ and the later P4 event are represented by smaller channels.

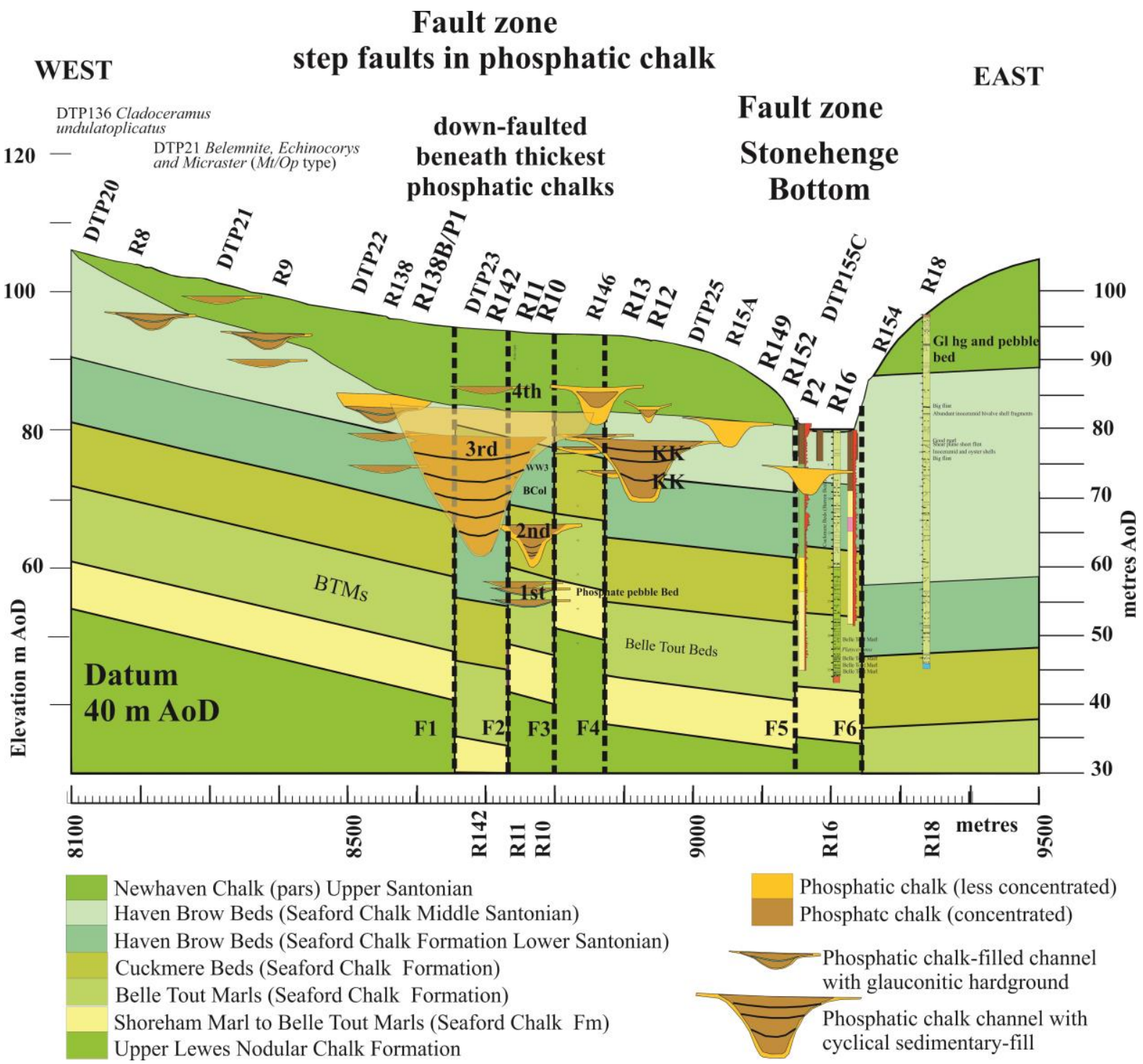

Figure 17a. Sedimentary model 1: A simplified multichannel interpretation for the Stonehenge phosphatic-chalks (boreholes and trial pits removed, see Figure 16a,b). The third main phosphatic-chalk event in Borehole R11 (labelled $3^{\text {rd }}$ ) fills a deep channel in the downfaulted area between faults F1 and F2, the location of borehole R142. The second deep channel with thick phosphatic-chalks in borehole R12 is in the down-faulted area between faults F4 and F5. 


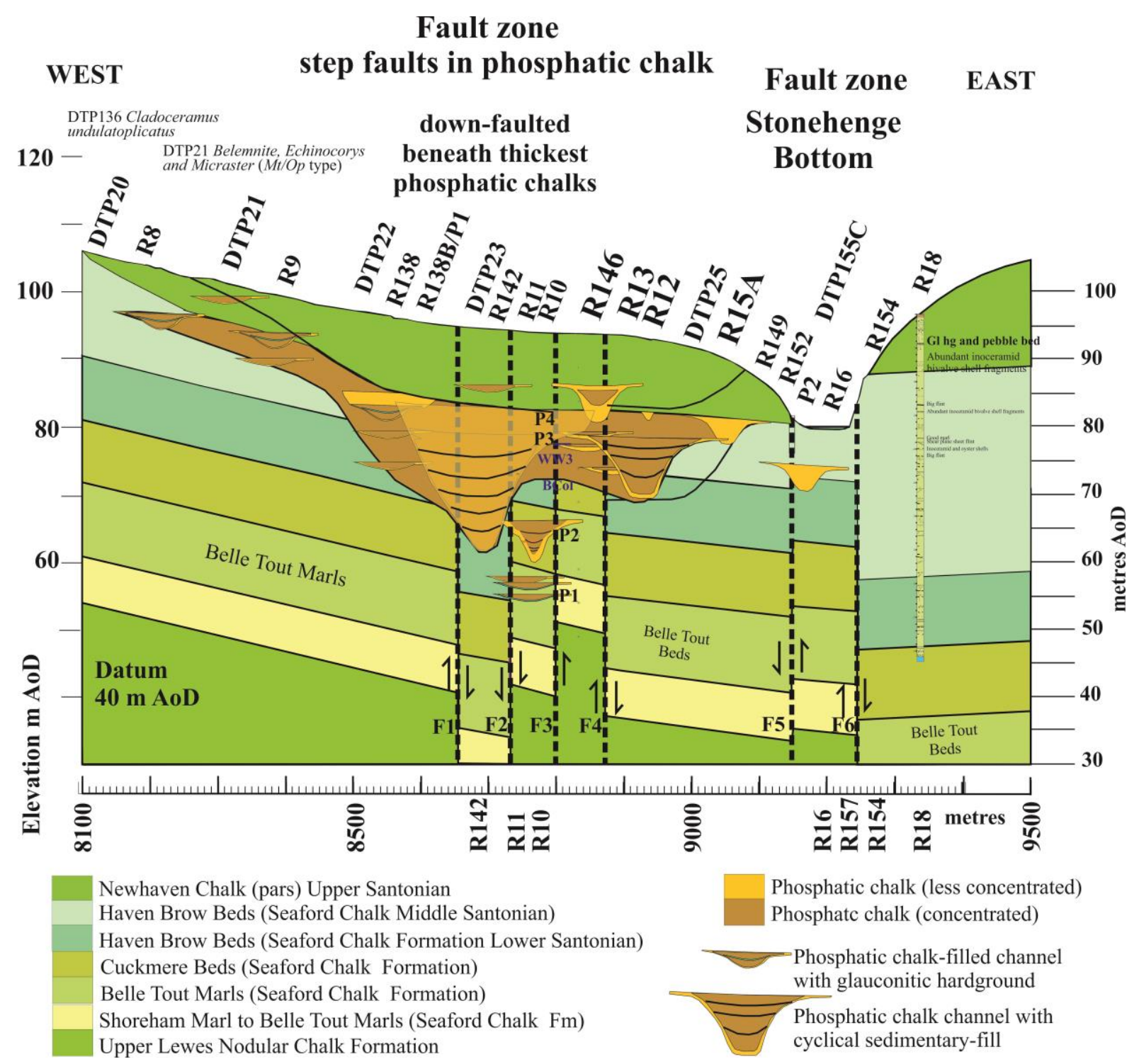

Figure 17b Sedimentary model 2: a possible large single channel linking the two thickest deposits of phosphatic-chalk in boreholes R142 and R12. The thickest phosphatic-chalks (P3) are located in a down-faulted zone between faults F1 and F2 and between faults F4 and F5 with thinning step-faulted eastwards across faults F2, F3 and F4. Phosphatic-chalk Events P1 and $\mathrm{P} 2$ and the later $\mathrm{P} 4$ event are represented by smaller channels. (Modified from Mortimore, 2011, 2014). 


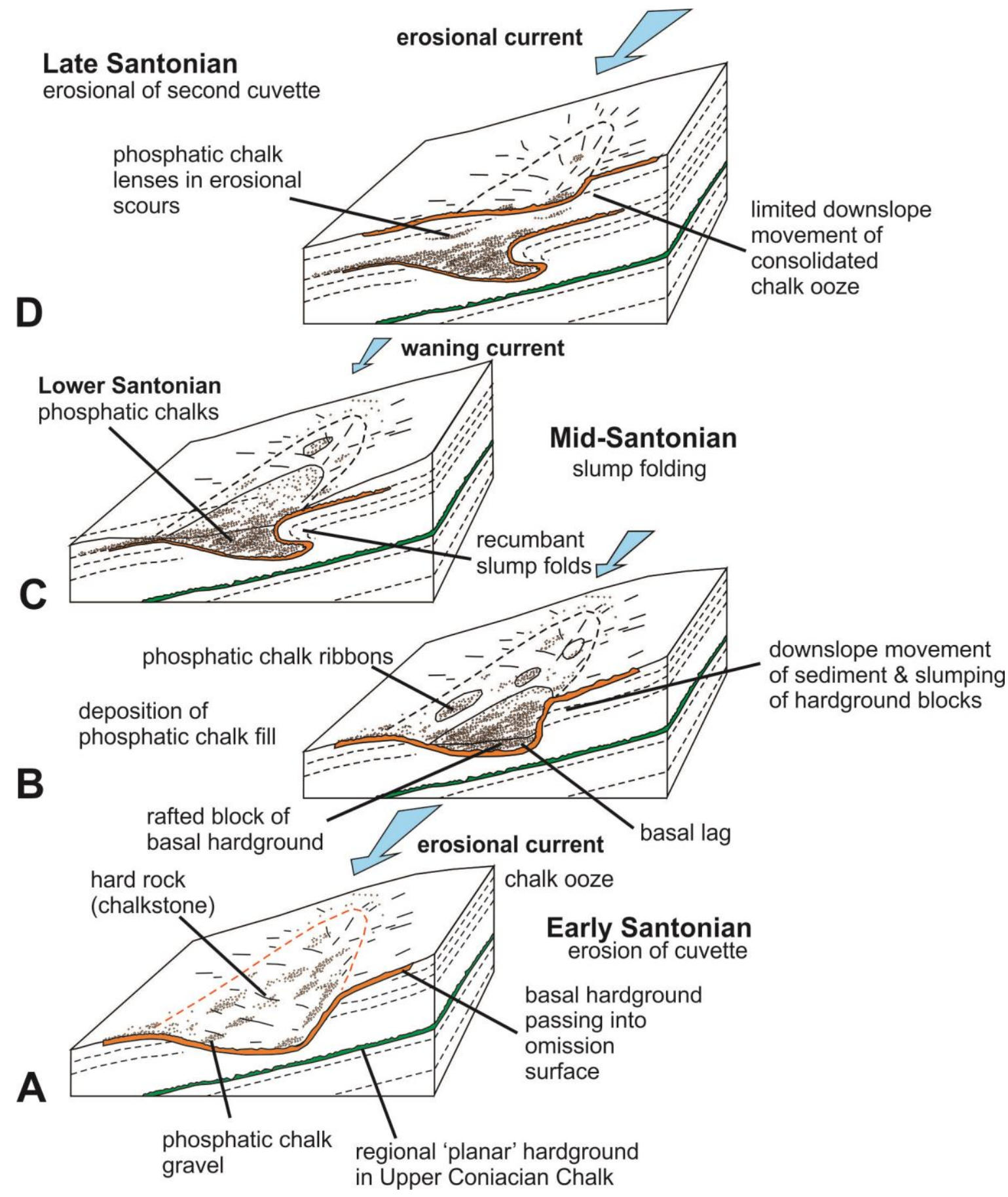

Figure 18. The 'cuvette' model for the formation and deposition of phosphatic-chalks (modified from Jarvis, 2006). This model partly explains the origin of the Stonehenge deposits, especially the smaller channels. It does not explain the origin of the thickest deposits. The Stonehenge deposits appear not to have a basal hardground or have formed on a slope as suggested in this model. Fault controlled subsidence appears to be the main mechanism in conjunction with submarine erosion (Figure 17). The geological ages for the Stonehenge phosphatic chalks also cover a greater range from Middle Coniacian to Late Santonian but the main event with thickest deposits is mid-Santonian (see Figure 8). 


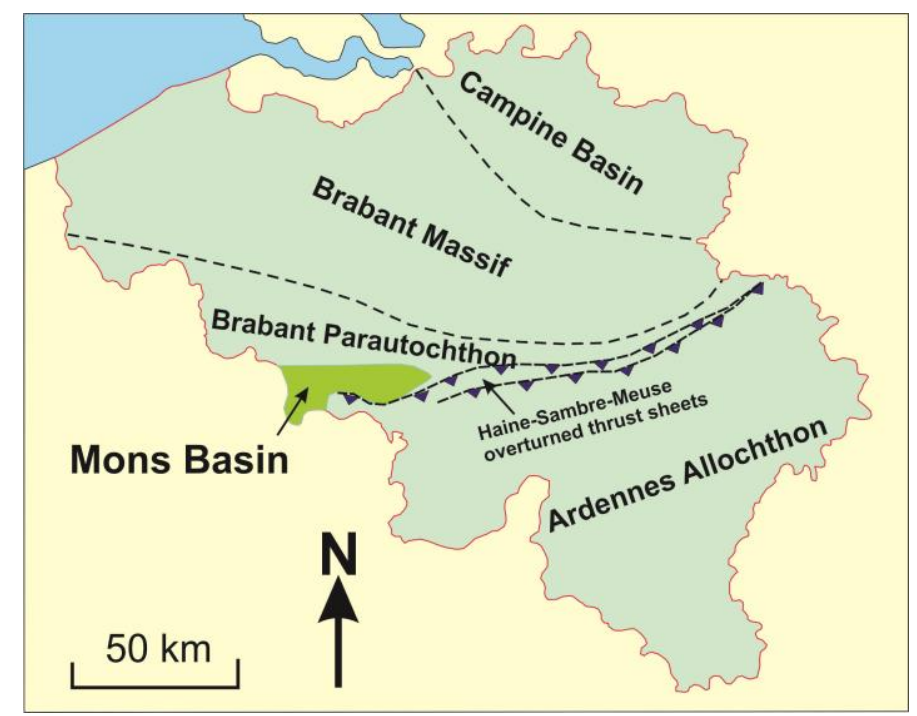

Figure 19. Location of the Mons Basin, Belgium, closely associated with a complex tectonic region probably controlling subsidence and space for the phosphatic-chalks.

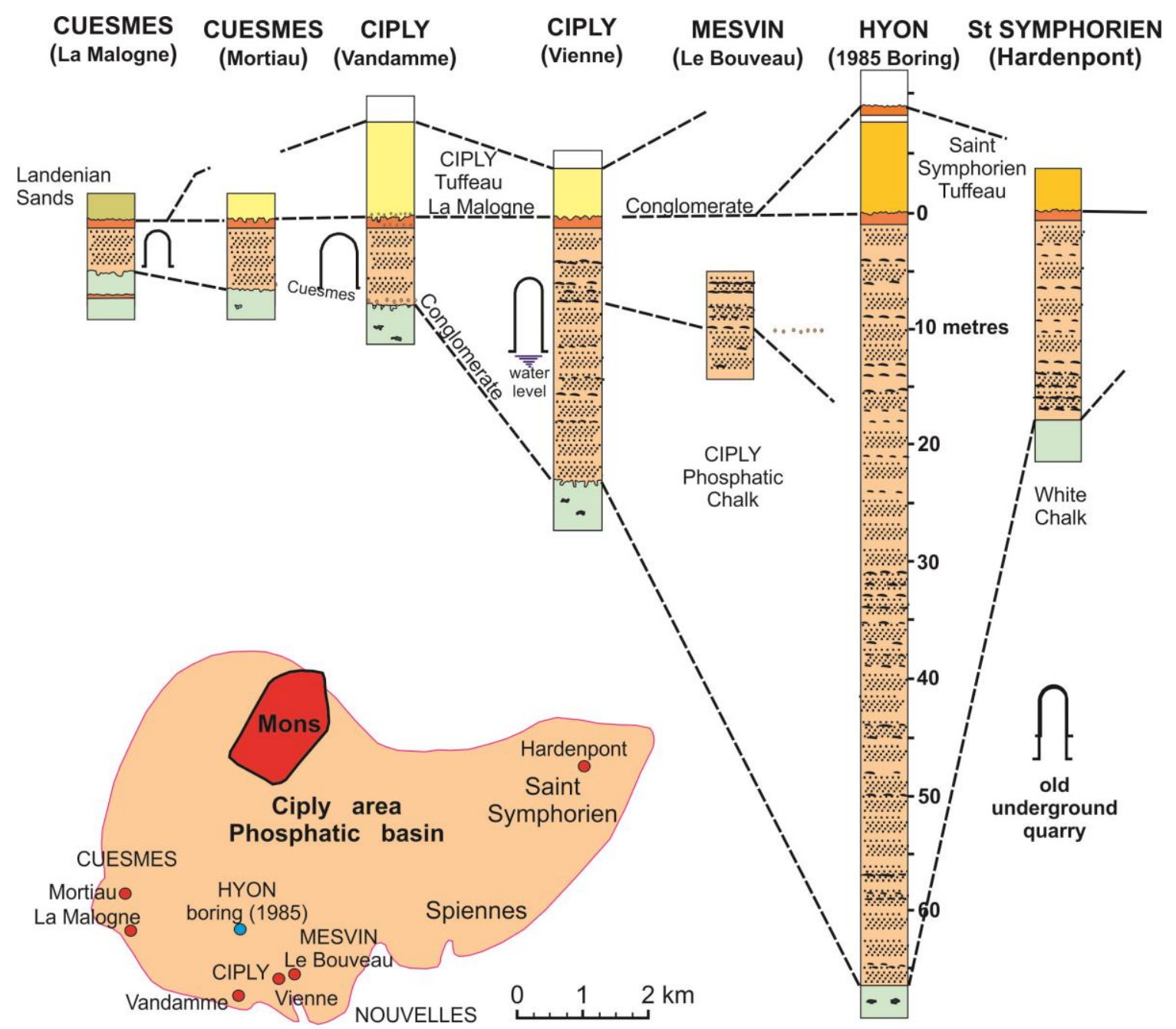

Figure 20. Sections through the Maastrichtian Ciply phosphatic chalk, Mons Basin, Belgium. Note absence of hardgrounds except at the top of the deposit (from Robaszynski and Martin, 1988; Robaszynski, 1995) 


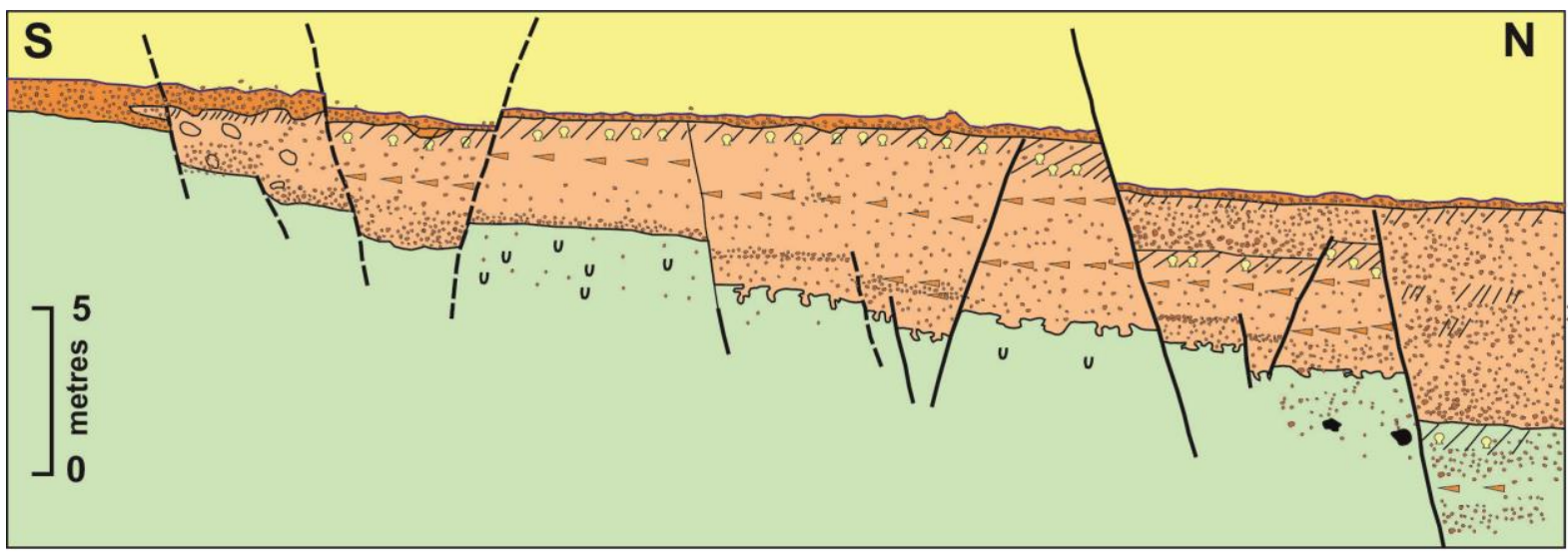

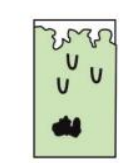

Craie de

Spiennes

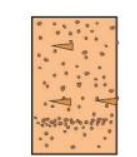

Craie phosphatée de Ciply

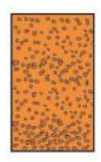

Tuffeau de Saint-Symphorien

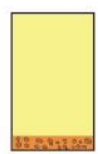

Pecten

Belemnite

Tuffeau de

Ciply
Induration/ छr שr Hardground "///"

Phosphatic grains

Schematic illustration of the underground phosphatic chalk mines of La Malogne, Mons Basin, Belgium

Figure 21. Fault pattern showing thickness of phosphatic chalks increasing across synsedimentary faults in the La Malogne underground quarry, Ciply Phosphatic Chalk, Mons Basin, Belgium (after Vandycke et al., 1991).

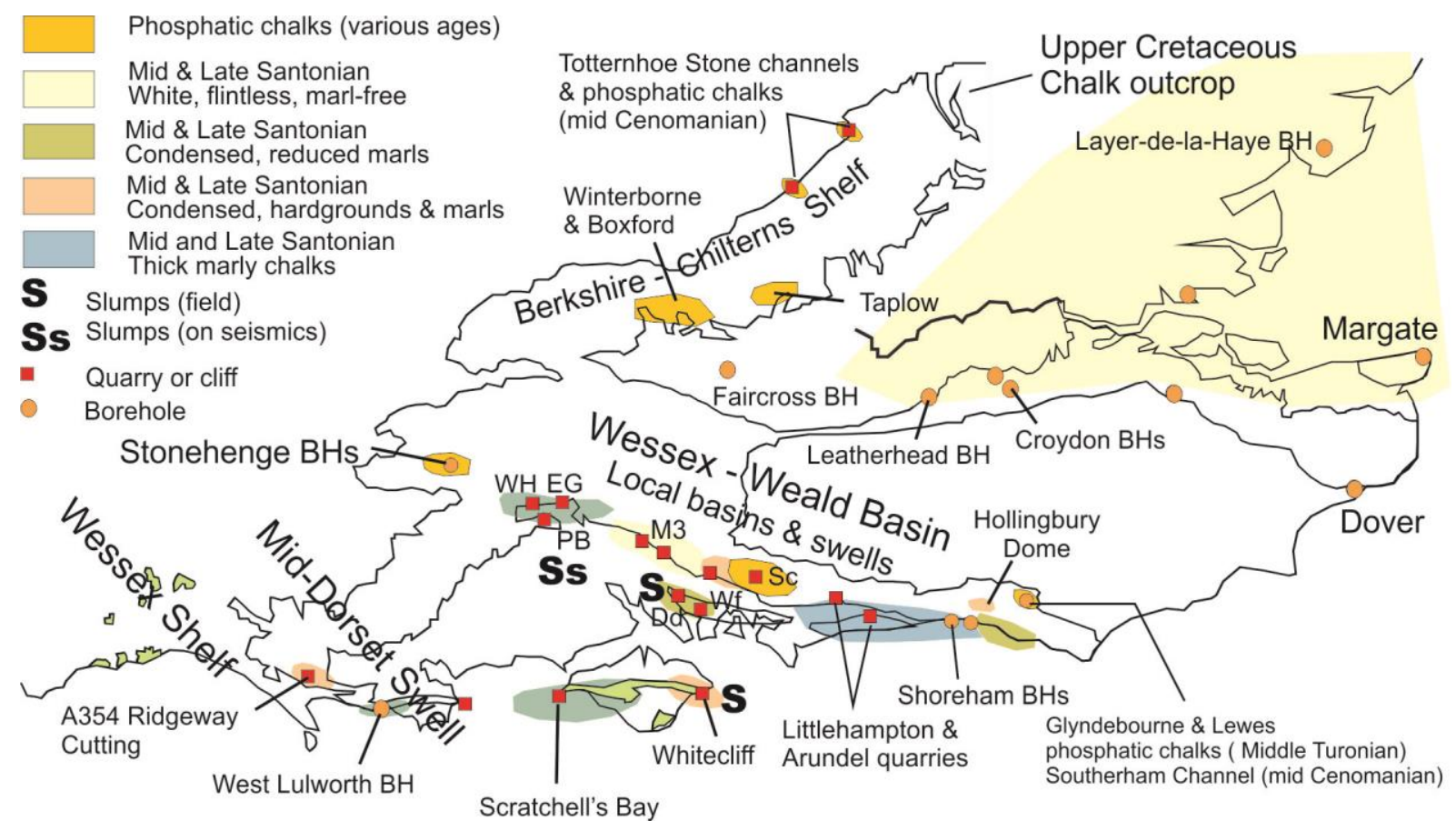

Figure 22. Distribution of phosphatic-chalks in time and place in England and correlative, thicker successions (modified from Mortimore, 2011). 


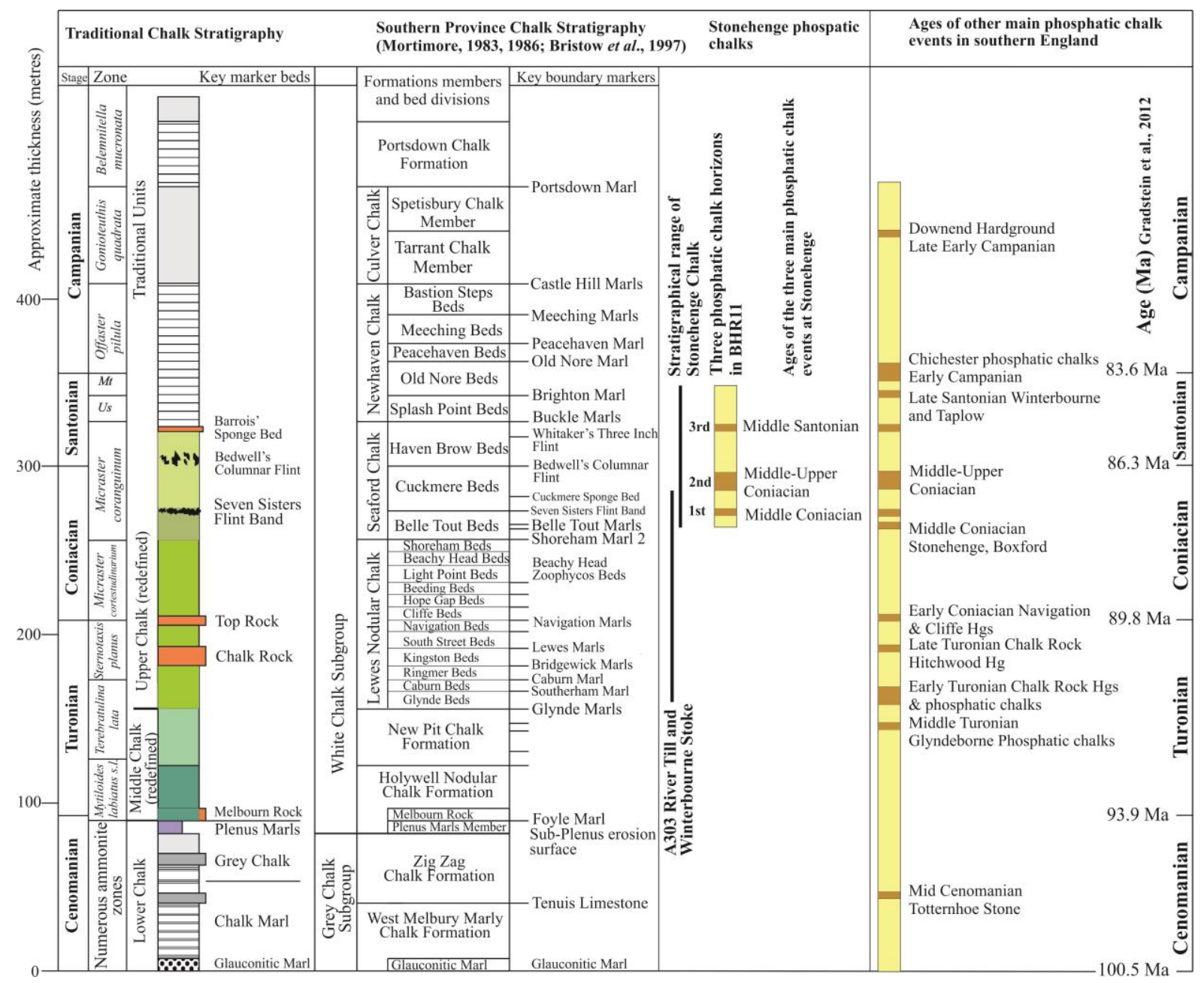

Figure 23. Generalised stratigraphical column for the Chalk of southern England showing the position of the Stonehenge phosphatic chalks and the stratigraphical range for the wider investigation A303 Amesbury to Winterbourne Stoke investigations (compare with Figure 5). The stratigraphical position of other phosphatic-chalks in southern England is also shown (compare with Figure 22). Geological ages/timescale after Gradstein et al., 2012. 


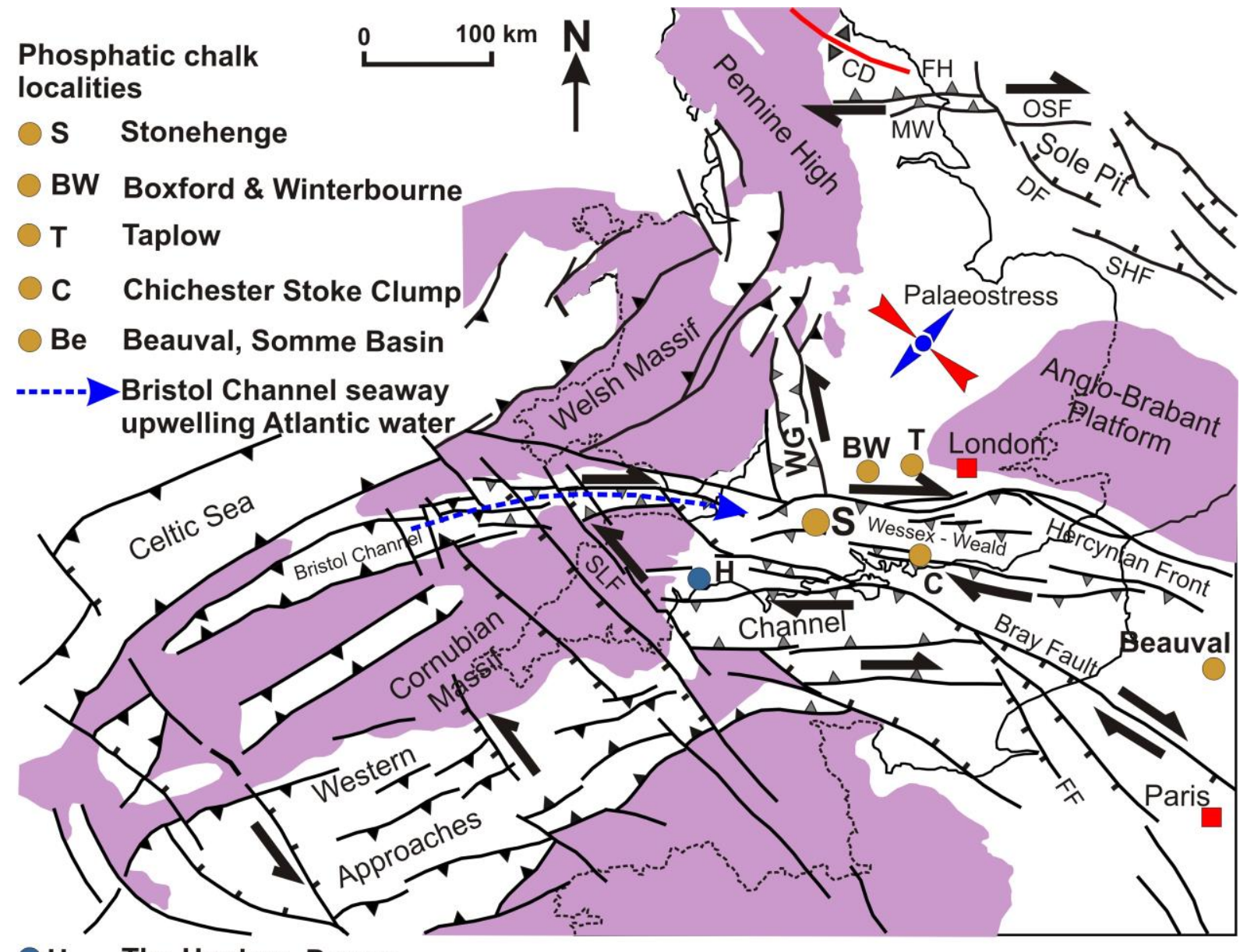

H The Hooken, Devon
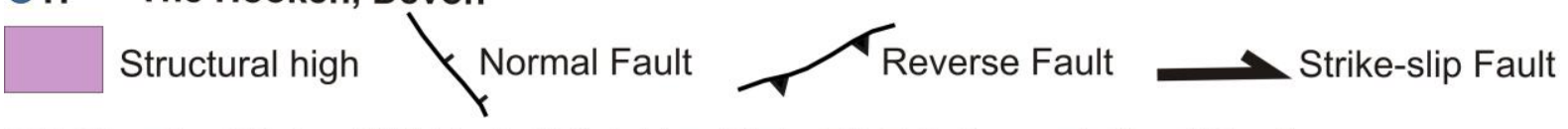

CD Cleveland Dyke MW Market Weighton High FH Falmborough Head Faults

OSF Outer Silver Pit Fault DF Dowsing Fault SHF South Hewett Fault FF Fécamp Fault SLF Sticklepath-Lustleigh Fault WG Worcester Graben

Figure 24. Structural setting of the Stonehenge phosphatic-chalks in relation to the palaeostress acting in the European Platform in the Late-Cretaceous-Early Cenozoic and the Bristol Channel seaway between the Cornubian and Welsh massifs. Rejuvenation of the basement framework of faults during African-European Plate movements are probable causes of the fault movements at Stonehenge. (Map based on Hibsch et al., 1993, 1995) 


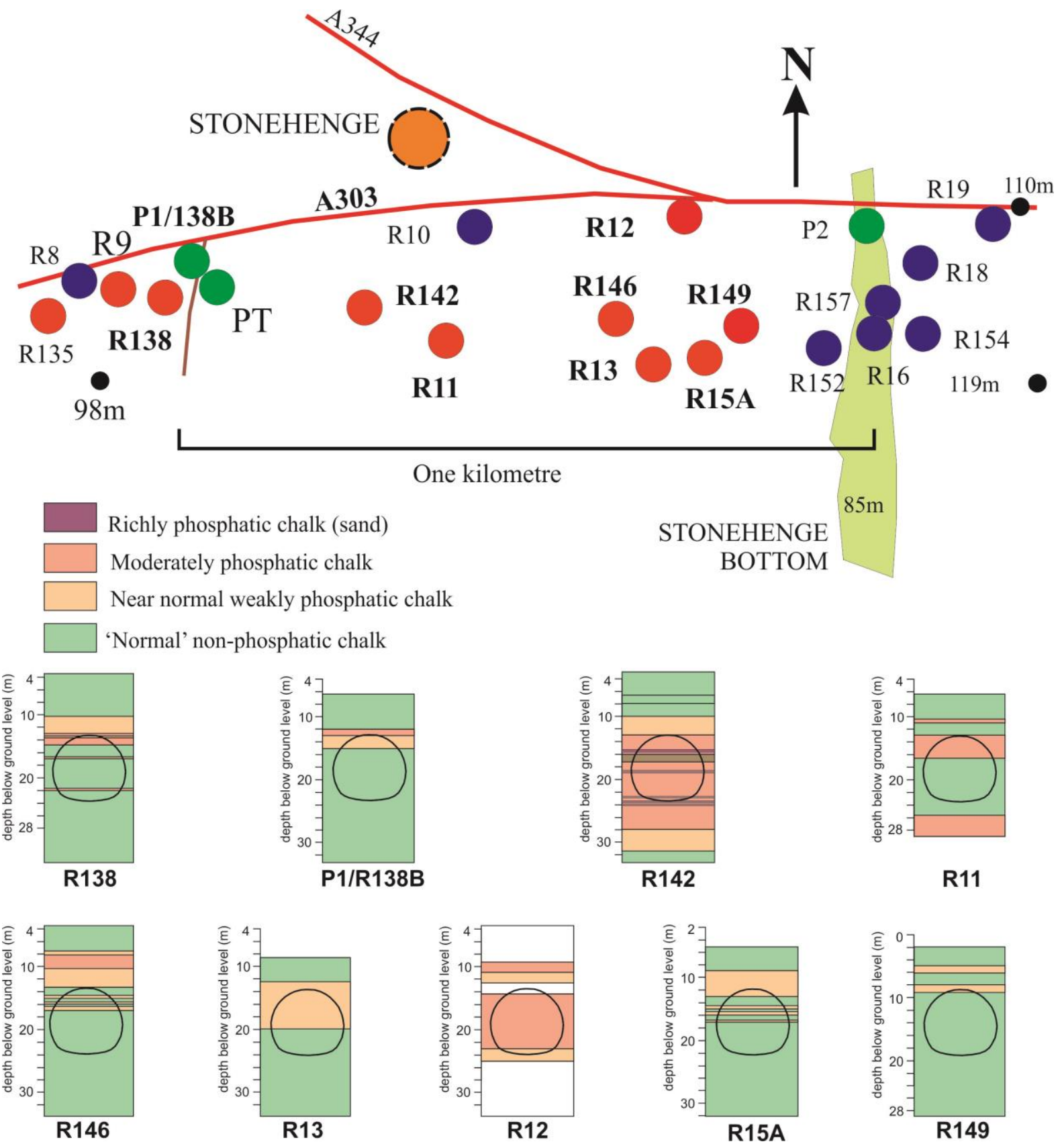

Figure 25. A303 Stonehenge proposed twin road tunnels original alignment; typical cross sections of tunnel faces showing lithological variability to expect based on borehole logs through the phosphatic-chalks. This figure illustrates the frequency of potentially unstable tunnel crown conditions with overlying phosphatic chalks, a key issue in the escalating cost of tunnelling and eventual cancellation of the project. 


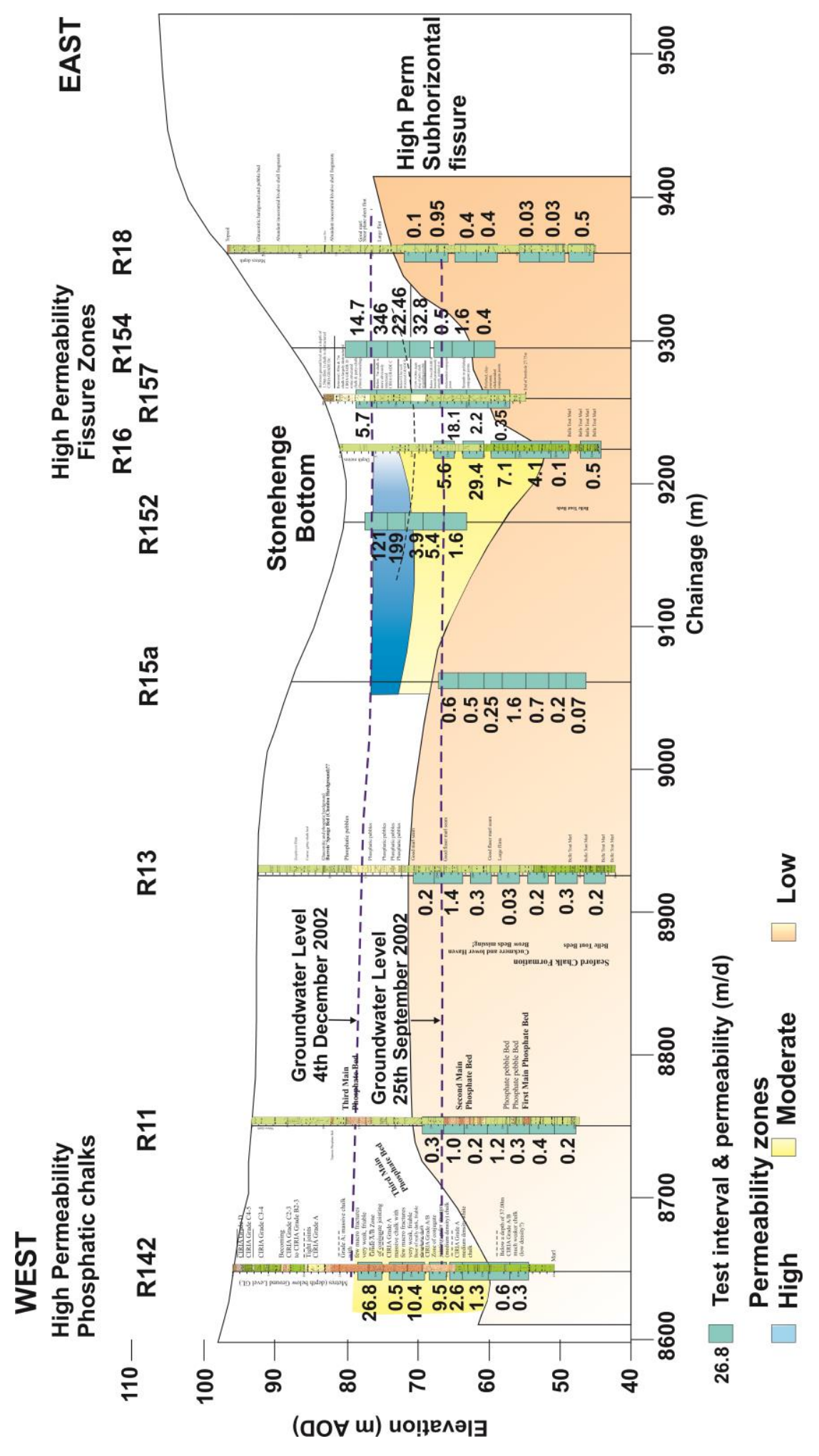

Figure 26. A303 Stonehenge Tunnel section Packer Test permeability profile showing increased permeability (metres per day) in the thicker phosphatic-chalks (Borehole R142) and in fracture zones associated with the dry valley, Stonehenge Bottom. In the tighter rock towards the interfluve on the east side of Stonehenge Bottom groundwater permeability is focussed along a subhorizontal fissure (Borehole R18). Note the rapid rise in groundwater (watertable) between September and December 2002. 


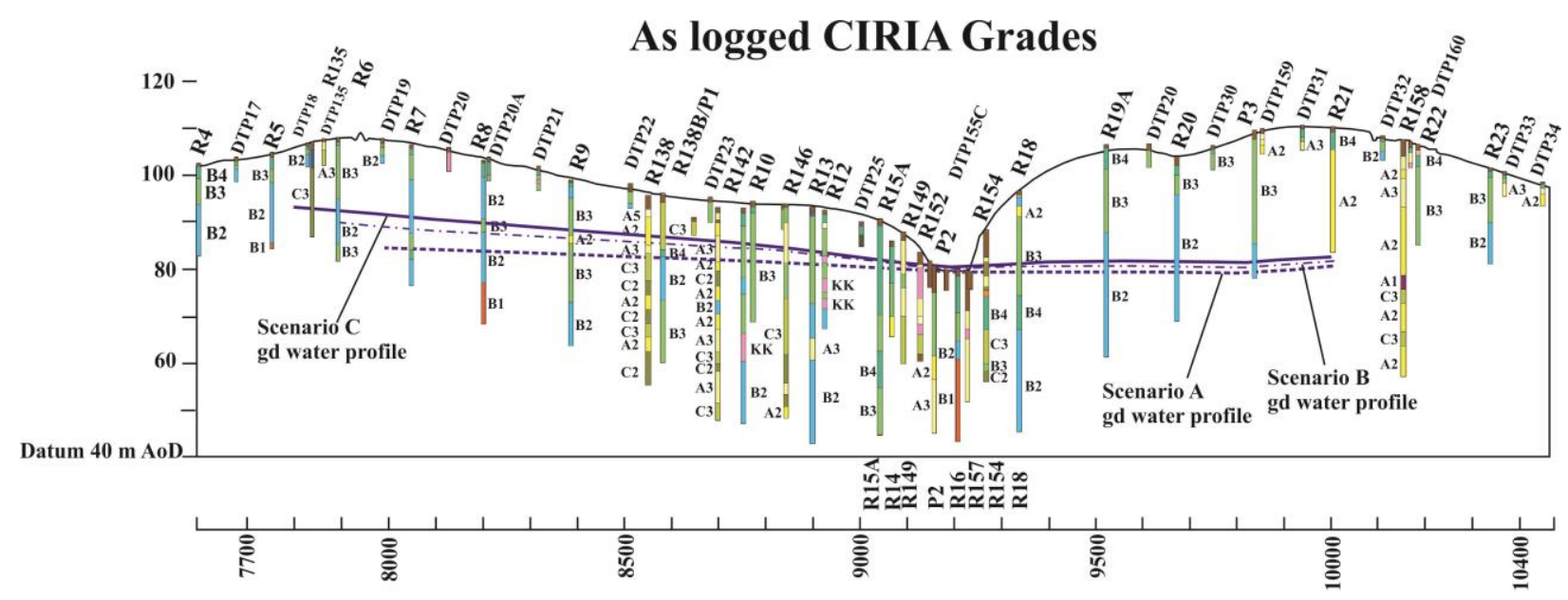

Figure 27a. CIRIA grades represent the state of fractures (fill, aperture, frequency) with Grade A being closed, Grade B slightly open, Grade C open heavily stained with fill and Grade D degraded chalk that has lost its structure. $\mathrm{K}=$ karst feature. Scenario A, B, C refer to groundwater levels recorded during the later stages of the ground investigation and possible groundwater levels to expect during tunnel construction.

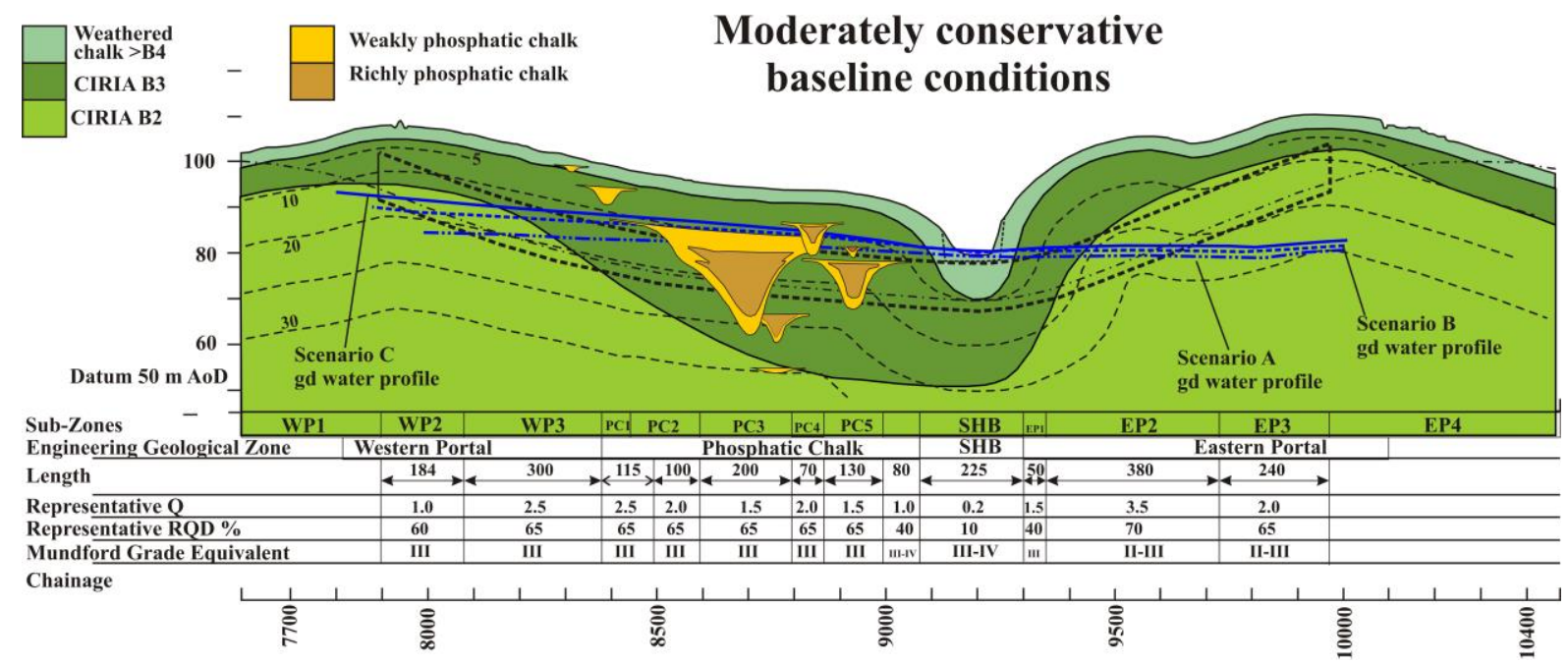

Figure 27b. A combination of stratigraphy, lithology, CIRIA grade (weathered profile) and groundwater profile is used to assess risks and baseline conditions for tunnelling. This moderately conservative model assumes several small channels and therefore shorter length of tunnel in the phosphatic-chalks. It also assumes no faults or major fracture zones are present. 


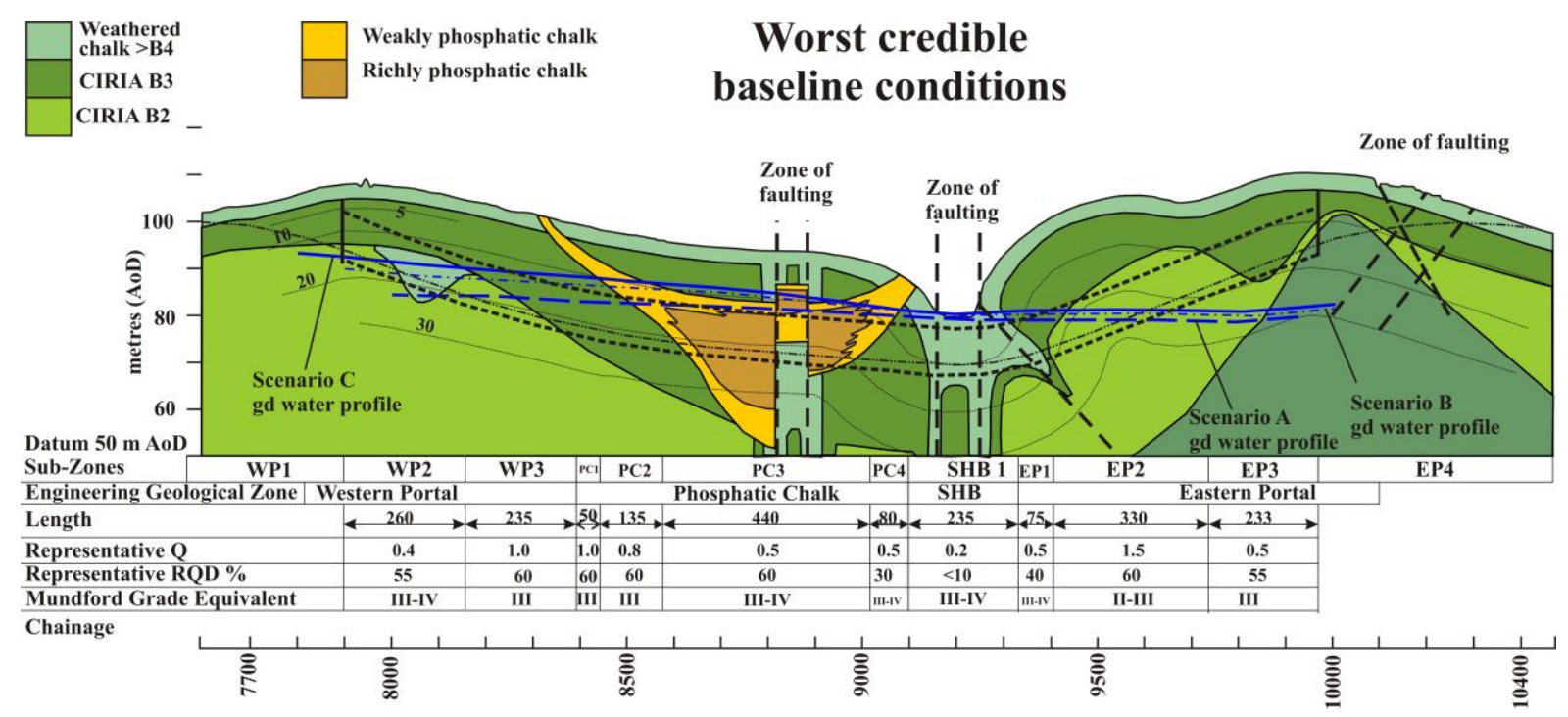

Figure 27c. This worst case model assumes the presence of one large synsedimentary phosphatic-chalk-filled channel and, therefore, longer lengths of tunnel in the phosphaticchalks. The model also includes several zones of faulting and deeper weathering along fault zones and the dry valley, Stonehenge Bottom. 


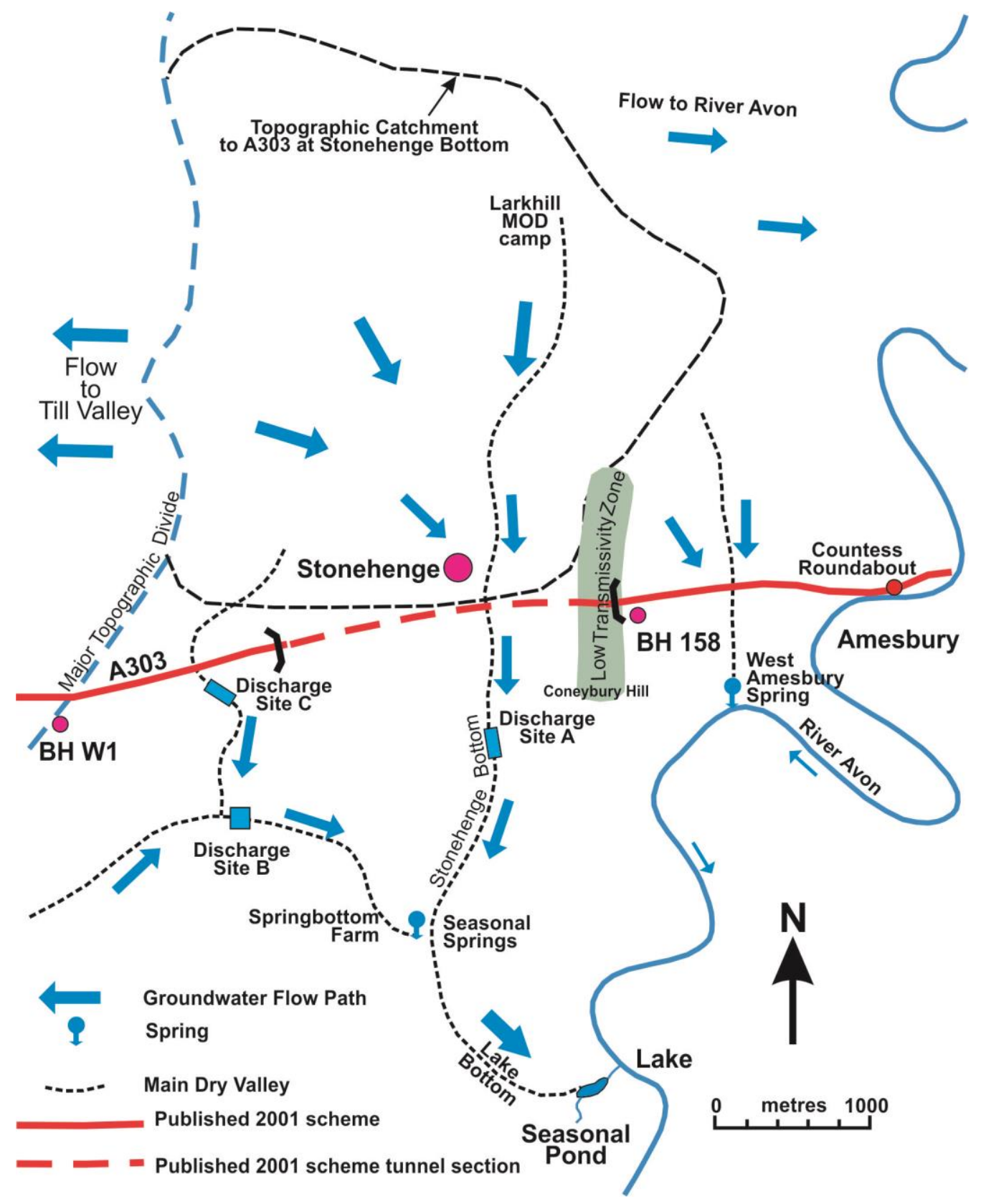

Figure 28. A303 Stonehenge tunnel area conceptual groundwater flow regime. Stonehenge Bottom acts as a drain to the area with a spring located downstream at Springbottom Farm and a seasonal pond in Lake Bottom close to the River Avon. During the rapid rise in groundwater levels in 2002 the floor of Stonehenge bottom became flooded up to the A303 crossing and Trial Pits on the west side partly filled with water. 